\title{
Republic of Congo: Selected Issues
}

This Selected Issues paper for the Republic of Congo was prepared by a staff team of the International Monetary Fund as background documentation for the periodic consultation with the member country. It is based on the information available at the time it was completed on April 9, 2007. The views expressed in this document are those of the staff team and do not necessarily reflect the views of the government of the Republic of Congo or the Executive Board of the IMF.

The policy of publication of staff reports and other documents by the IMF allows for the deletion of market-sensitive information.

To assist the IMF in evaluating the publication policy, reader comments are invited and may be sent by e-mail to publicationpolicy@imf.org.

Copies of this report are available to the public from

International Monetary Fund $\bullet$ Publication Services

700 19th Street, N.W. • Washington, D.C. 20431

Telephone: (202) 6237430 • Telefax: (202) 6237201

E-mail: publications@imf.org • Internet: http://www.imf.org

Price: $\$ 18.00$ a copy

\section{International Monetary Fund Washington, D.C.}





\section{INTERNATIONAL MONETARY FUND}

\section{REPUBLIC OF CONGO}

\section{Selected Issues Paper}

Prepared by Abdelrahmi Bessaha, Francis Bokilo, Joseph Karangwa, Yinqiu Lu, Joannes Mongardini, Yaya Moussa (all AFR), Stephane Carcillo (FAD), Jean-Pierre Nguenang (FAD expert), and Maria Oliva (PDR)

Approved by the African Department

April 9, 2007

Contents

I. The Challenges of Sustainable Growth in the Republic of Congo ………......................5

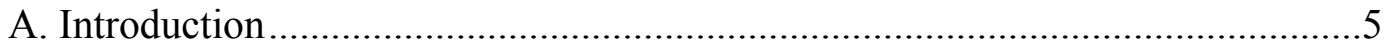

B. Pillar I: A Sustainable Medium-Term Fiscal Strategy ……………....................5

C. Pillar II: Improving the Quality of Public Spending and Transparency of the Budgetary Process ..................................................................................6

D. Pillar III: Reducing the Cost of Doing Business...............................................

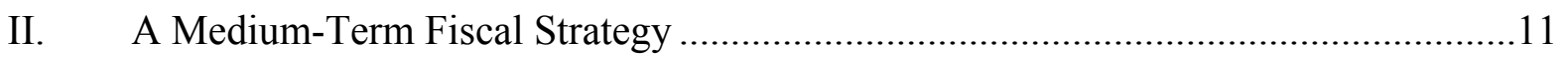

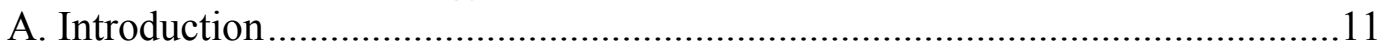

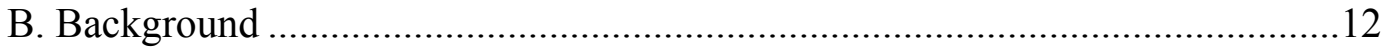

C. Key Elements of a Medium-Term Fiscal Strategy ...........................................16

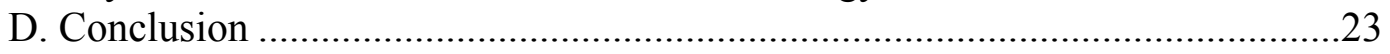

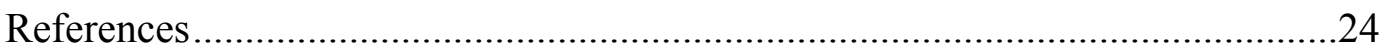

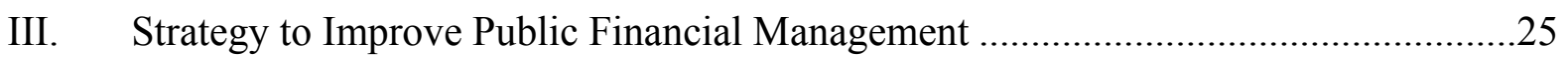

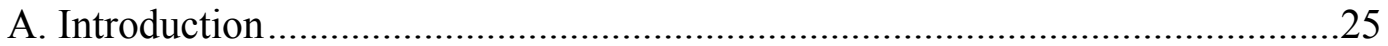

B. An Assessment of the Quality of the PFM System..........................................26

C. Key Public Financial Management Issues …………....................................2

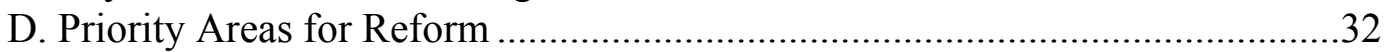

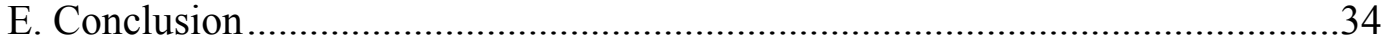

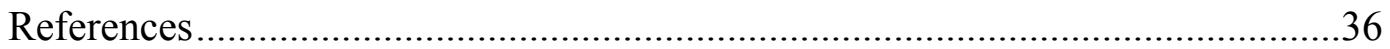


IV. Governance and Transparency in the Republic of Congo ............................................38

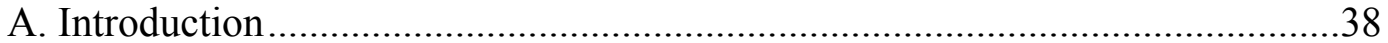

B. Governance, Growth, and Competitiveness .......................................................39

C. Causes and Consequences of Weak Governance and Corruption.......................40

D. Governance in CEMAC Countries ..............................................................44

E. Congo's Record on Governance...................................................................47

F. Strengthening Governance and Fighting Fraud...............................................4

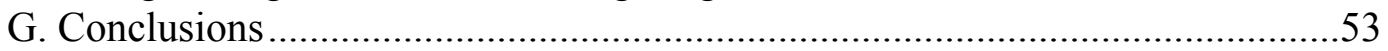

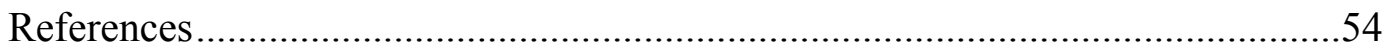

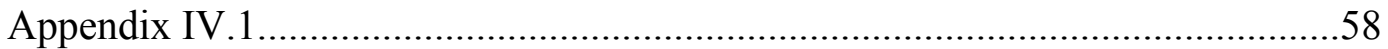

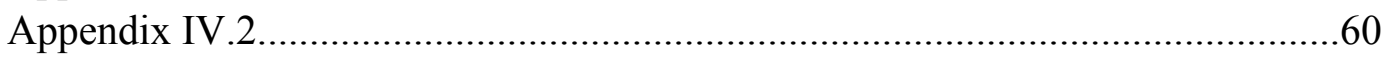

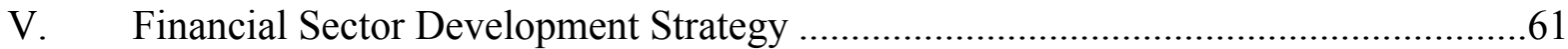

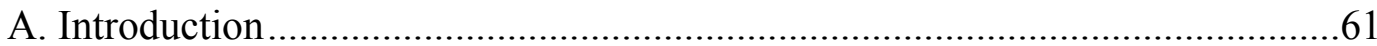

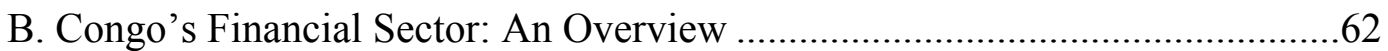

C. A Strategy to Improve Access to Financial Services ..........................................73

D. Strategy to Improve the Soundness of the Financial Sector ...............................76

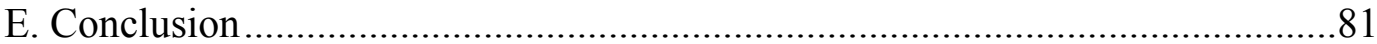

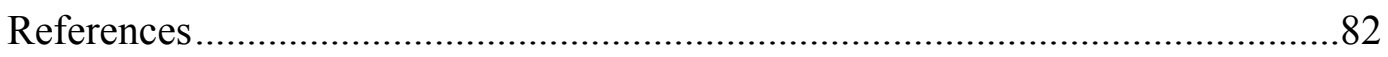

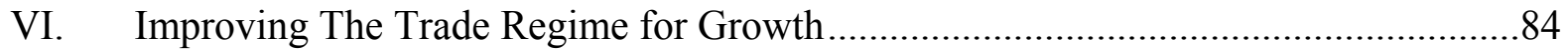

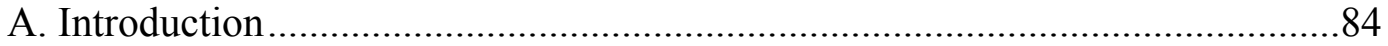

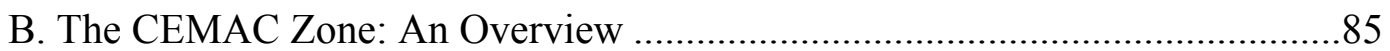

C. Congo's Trade Regime: Theory and Practice ...................................................89

D. A Strategy to Simplify Congo's Trade Regime .................................................92

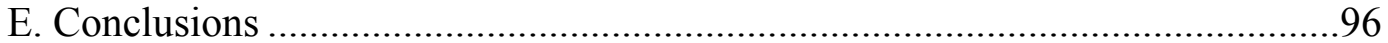

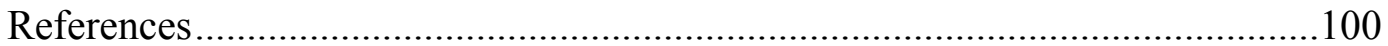

Tables

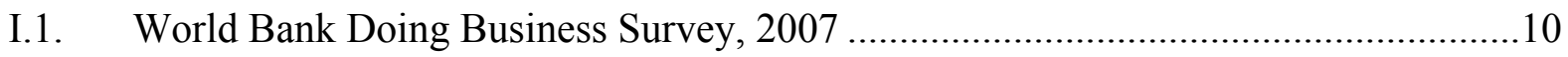

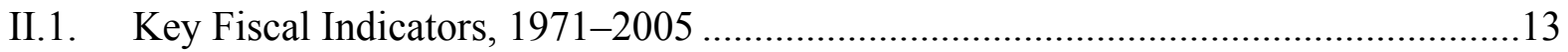

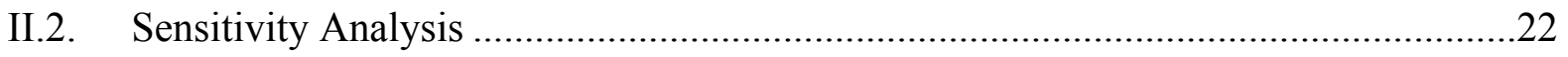

III.1. Evaluation of Unallocated Appropriations in the Ministries Spending

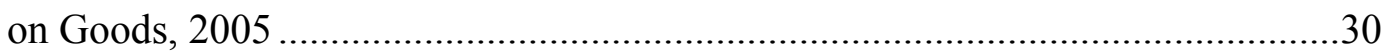

IV.1. Six Indicators on Governance: CEMAC Performance ...............................................46

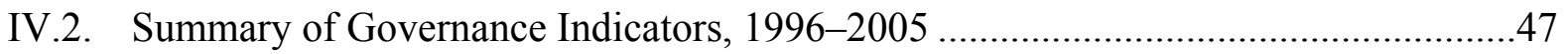

IV.3. The Correlation between Alternative Indicators of Governance .................................4

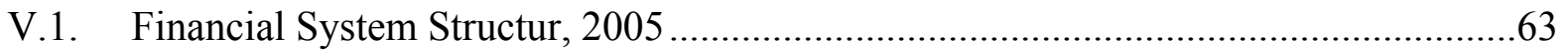

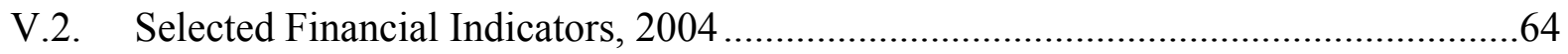

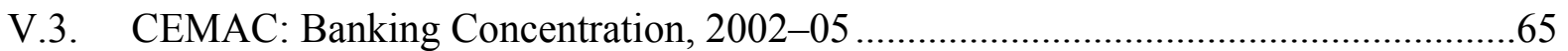

V.4. Commercial Bank Deposits and Credit Structure, 2002-05 ………………..............67

V.5. Financial Soundness Indicators for the Banking Sector .............................................69

V.6. Number of Banks Complying with Prudential Ratios …………..................................70

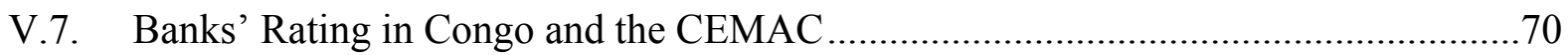


V.8. Recent Developments in Microfinance Activity …………......................................

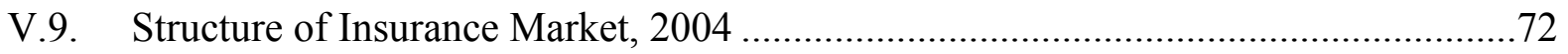

VI.1. The Common External Tariff by Regional Agreement ...............................................8

VI.2. Comparison of MFN Rate Across the CEMAC, WAEMU, and East African

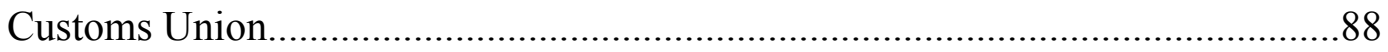

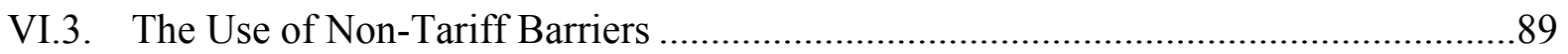

VI.4. Congolese Tariff Code: Summary of Main Instruments.............................................90

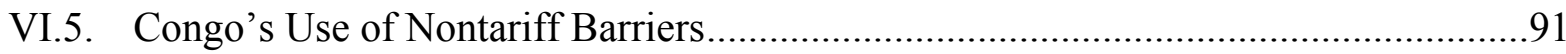

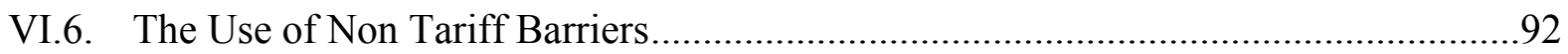

VI.7. Revenue from Taxation of International Trade …….............................................94

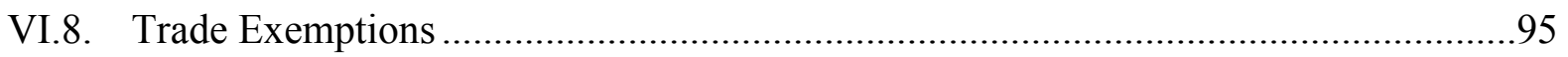

VI.9. Revenue from Taxation of International Trade ……................................................95

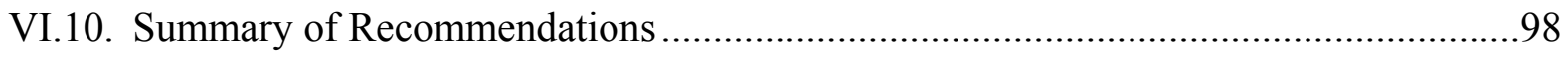

Figures

I.1. Oil Producing Countries: Non-Oil Primary Balance, 2002-06 ...................................6

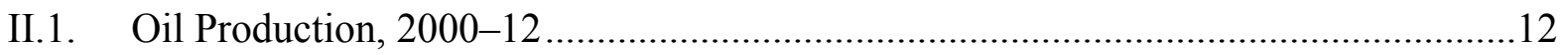

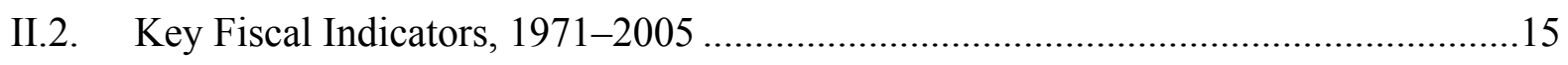

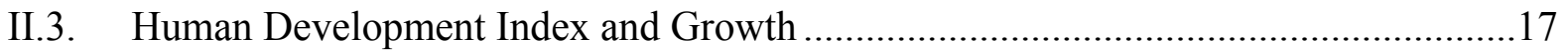

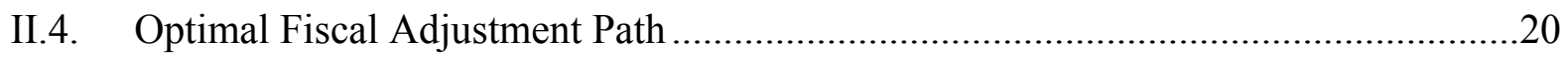

II.5. Tradeoff Between Adjustment Speed ..................................................................2

III.1. Assessment of the Quality of the Public Financial Management System, 2006 ........27

IV.1. Competitiveness and the Control of Corruption and the Rule of Law ........................41

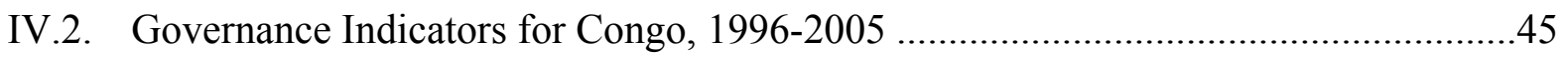

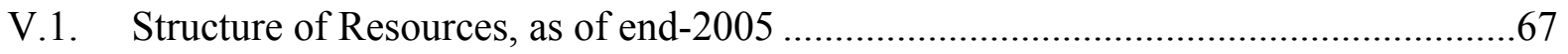

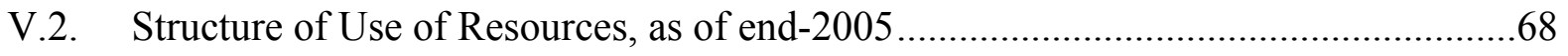

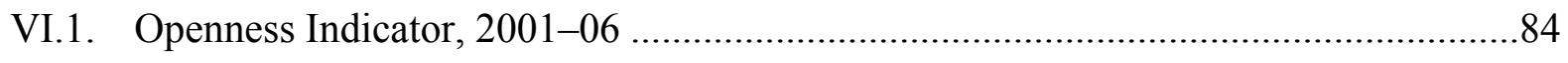

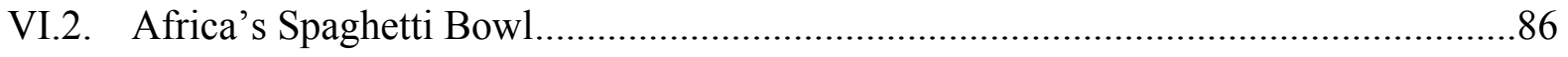


Boxes

II.1. The Oil Sector in the Republic of Congo ..... .13

II.2. Calibration of the model for the Republic of Congo ................................................19

IV.1 Literature on Causes of Weak Governance and Corruption .....................................42

IV.2. Consequences of Weak Governance and Corruption ............................................43

IV.3. 2003 Corruption Survey: Five Main Findings ............................................................49

IV.4. Government Responses to the 2003 Corruption Survey ..........................................50

IV.5. Congo's Progress on Governance Since 2003 ........................................................51

VI.1: The Case of Cement ....................................................................................... 93 


\section{The Challenges of Sustainable Growth in the Republic of Congo ${ }^{1}$}

\section{A. Introduction}

1. The Republic of Congo (hereafter the "Congo") is at a crossroads. The large increase in oil exports and fiscal revenues over the last two years, together with the prospects of debt relief under the Enhanced HIPC Initiative, have created favorable financial conditions that could engender a path of higher sustainable growth over the medium-term and enable the country to reach the Millennium Development Goals (MDGs). Such an outcome will critically depend on the authorities' policy choices.

2. Congo's experience during the 1980s demonstrates the importance of following a prudent approach to the use of oil resources. In the aftermath of the oil price shocks of the 1970s, the Congolese government implemented a procyclical fiscal policy which used oil revenues to increase government spending, with little regard to the quality of spending and its effect on growth and poverty alleviation. Such a policy did not help raise per capita income; further, it became unsustainable once international oil prices declined rapidly in the second half of the 1980s. By 1994, per capita income had fallen 10 percent compared with 1980, and external debt had reached 218 percent of GDP, the highest ratio in Africa.

3. It is paramount for the authorities to avoid repeating the experience of the 1980s, particularly in light of the projected decline in oil production over the next decade. The following papers propose a macroeconomic policy strategy that takes advantage of this unique opportunity to foster higher sustainable growth. The first pillar of this strategy is to pin down a sustainable medium-term fiscal strategy to avoid a repeat of the boom-andbust cycle of the 1980s. The second pillar aims at instituting reforms that will improve the quality of public spending and increase transparency in the budgetary process and in oil resource management. The third pillar consists of measures to reduce the cost of doing business in Congo, in order to attract investment, diversify the economy, and raise the economy's growth potential.

\section{B. Pillar I: A Sustainable Medium-Term Fiscal Strategy}

4. A sound macroeconomic policy in Congo should be anchored to a sustainable medium-term fiscal strategy (MTF) that takes into account the country's limited oil resources. As discussed in Chapter II, fiscal policy should help the accumulation of sufficient financial assets over time to prevent a decline in living standards as the country's oil resources are depleted. Such policy would acknowledge the nonrenewable nature of oil revenues, intergenerational equity considerations, and the need to build up a large amount of fiscal reserves that would generate a sufficient return to sustain government spending as a share of nonoil GDP even after oil production declines. The level of fiscal reserves needed

\footnotetext{
${ }^{1}$ Prepared by Joannes Mongardini.
} 
will critically depend on oil prices, the rate of return on financial assets, as well as on the growth of the non-oil economy.

5. Congo has one of the highest non-oil fiscal deficits in Africa (Figure I.1). The deficit is higher than Cameroon, Chad, and Gabon, and it is estimated to be higher than in Nigeria in 2006. More importantly, the non-oil primary balance has deteriorated significantly since 2003. Given that oil production will start declining in 2012 and will be exhausted in about 20 years at current extraction rates, such high deficits are clearly not sustainable.

Figure I.1. Oil Producing Countries: Non Oil Primary Balance, 2002-06

(Percent of non oil GDP)

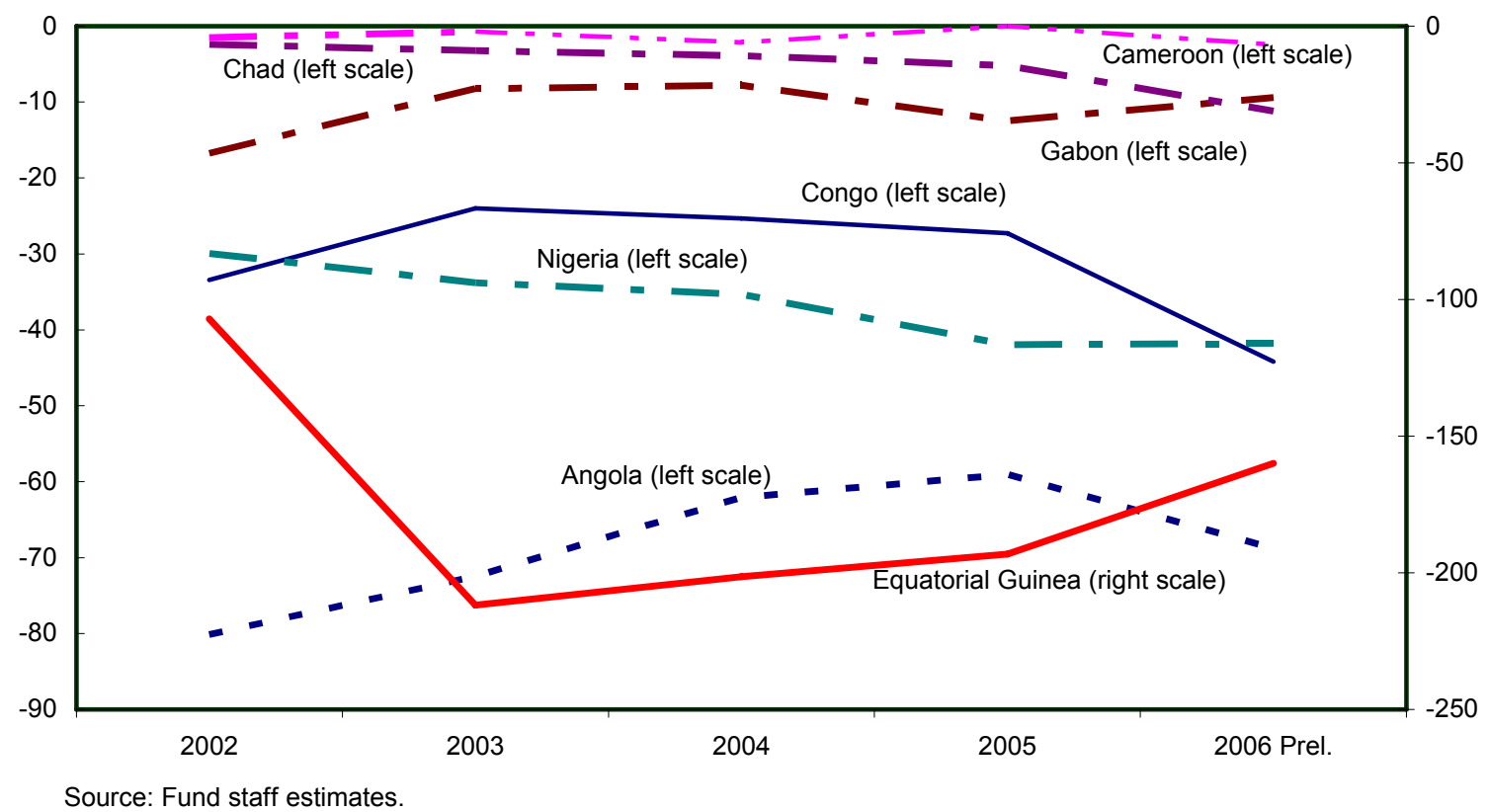

6. The analysis in Chapter II demonstrates the need for significant fiscal adjustment over the long run. There is, however, a clear need to strike a balance between sustainability considerations and the development needs of the country, including the scaling up of spending to reach the MDGs. The MTF strategy therefore should involve a gradual but sustained fiscal adjustment over the next twenty years in order to reach a sustainable non-oil fiscal balance by 2025, when oil production is expected to come to an end, while allowing sufficient fiscal space to reach the MDGs. This would imply a moderate but steady fiscal adjustment over the next twenty years of about 1.5 percent of nonoil GDP each year. The analysis also underscores the importance of increasing the returns on government financial assets and public investment to reduce the need for such a significant fiscal adjustment.

\section{Pillar II: Improving the Quality of Public Spending and Transparency of the Budgetary Process}

7. Within the envelope of a sustainable MTF strategy, the government will have a key role in fostering growth in the economy, by increasing pro-poor spending and 
improving the ailing infrastructure of the country. Years of civil war and neglect during the 1990s have left the country with poor education and health systems, an unreliable domestic energy sector, and poor transportation infrastructure. While the World Bank is best placed to provide advice on the best investment strategies for each of these sectors, the key to the success of these strategies is to establish institutional reforms aimed at improving the quality of public spending and further increasing transparency in the management of public resources.

8. The starting point for improving the quality of spending is a transparent budget classification. The authorities have committed to implementing a new functional classification in the budget, as part of the triggers for the completion point under the Enhanced HIPC Initiative, which will allow the tracking of poverty-related expenditures among other things. With technical assistance from the IMF Fiscal Affairs Department, technical work in this area is underway and the new nomenclature is expected to be in place to monitor the 2007 budget on a trial basis. It will be operational for the 2008 budget.

9. Strengthening budget execution is another critical aspect. This would require:

(i) the implementation of a new public investment management system, aimed at providing a rigorous selection and efficient execution and monitoring of projects; (ii) a new procurement code in line with best international standards to ensure a transparent and competitive public procurement; and (iii) the strengthening of the tracking and monitoring of government spending at various stages of the expenditure chain (commitment, issuance of payment orders, and cash payments).

10. A more transparent management of oil resources is also crucial. Efficient oil revenue management in Congo requires that the national oil company, the SNPC, improves its management of the country's oil resources and performs its fiscal agency role in a more cost-effective, accountable, and transparent manner. Performance in line with international standards should be monitored on a regular basis wherever possible. Information disclosure requirements relating to the activities of the SNPC should be guided by the standards of the Extractive Industries Transparency Initiative (EITI).

\section{Finally, greater transparency and accountability are needed in awarding oil} concessions. As shown in the Marine XI oil concession, a non-transparent system of awarding oil concessions can lead to conflict of interests at the expense of government revenue. Future oil concessions should therefore be awarded based on a transparent bidding process, starting with the publication on the government website of the criteria for awarding the concession as well as the bids after they have been received.

\section{Pillar III: Reducing the Cost of Doing Business}

\section{The diversification of Congo's economy is highly dependent on a significant} reduction of the cost of doing business. As shown by the World Bank's DoingBusiness 
database, ${ }^{2}$ Congo ranks one of the lowest countries in the World in terms of the ease of doing business (Table I.1). Of particular concern are the cost of starting a business, employing workers, registering property, getting credit, paying taxes, trading across borders, and enforcing contracts, where Congo lags behind not only OECD averages, but also most other African countries. Overall, the World Bank database makes it clear that Congo has a long way to go to be an attractive place for private sector investment.

\section{The starting point for reducing the cost of doing business is to improve} governance. As shown in Chapter IV, corruption is widespread in the country, imposing significant and nontransparent costs that hinder investment activity. Therefore, the establishment of transparent institutions and good governance practices are critical to tackling corruption and fostering the conditions for higher nonoil growth. The public sector can take the lead in transparent budgetary processes, procurement procedures, and greater transparency in oil resource management. In addition, the Doingbusiness database highlights the need to streamline the process of paying taxes, as Congolese businesses are required to make 2.3 times more payments and spending 50 percent more time doing so than other African countries (payments and time spent are almost six and three times the OECD average, respectively).

\section{Financial sector development is another critical factor in helping foster} economic growth. As outlined in Chapter V, access to financial services in Congo is very low and is available only to wealthy customers in urban areas. Developing the financial sector will require: (i) widening public access and lowering the cost of financial services by promoting the introduction of new financial instruments such as credit cards, automatic teller machines, and micro credits; (ii) increasing competition through an open policy to licensing banks, liberalizing deposit and lending rates, the ability of microfinance institutions to compete with banks effectively, and cross-border competition within the CEMAC; and (iii) strengthening loan recovery procedures and widening the types of collaterals, which would help reduce interest spreads.

\footnotetext{
${ }^{2}$ See http://www.doingbusiness.org.
} 


\section{Third, a transparent trade regime is required to enhance growth prospects.}

Congo is part of the regional trade regime adopted by the CEMAC, but many of the trade practices both at a regional and a national level create significant obstacles to trade. Tariffs are high, exemptions are widespread (particularly for the oil sector), documentations for exports and imports are onerous, and effective pre-shipment inspections are lacking. In addition, trade with the Democratic Republic of Congo (DRC) - a natural trading partner due to its proximity - is hampered by different trade regimes and lack of transport infrastructure across the Congo river. The authorities should remove these trade rigidities by spearheading trade reform in the CEMAC countries, adopting a transparent trade regime, minimizing bureaucratic procedures for exports and imports, gradually phasing out exemptions, and building the necessary infrastructure for trade with the DRC. 
Table I.1. World Bank Doing Business Survey, 2007

\begin{tabular}{|c|c|c|c|}
\hline Indicator & Congo & $\begin{array}{c}\text { Africa } \\
\text { Average }\end{array}$ & $\begin{array}{c}\text { OECD } \\
\text { Average }\end{array}$ \\
\hline \multicolumn{4}{|l|}{ A. Starting a Business } \\
\hline Number of procedures & 8.0 & 11.0 & 6.2 \\
\hline Time (days) & 71.0 & 61.8 & 16.6 \\
\hline Cost (\% of income per capita) & 214.8 & 162.8 & 5.3 \\
\hline Min. capital (\% of income per capita) & 192.4 & 209.9 & 36.1 \\
\hline \multicolumn{4}{|l|}{ B. Dealing with Licenses } \\
\hline Procedures (number) & 15.0 & 17.7 & 14.0 \\
\hline Time (days) & 175.0 & 230.2 & 149.5 \\
\hline Cost (\% of income per capita) & 1243.0 & 1024.5 & 72.0 \\
\hline \multicolumn{4}{|l|}{ C. Hiring and Firing Workers } \\
\hline Difficulty of hiring index & 78.0 & 44.3 & 27.0 \\
\hline Rigidity of hours index & 60.0 & 52.0 & 45.2 \\
\hline Difficulty of firing index & 70.0 & 44.9 & 27.4 \\
\hline Rigidity of employment index & 69.0 & 47.1 & 33.3 \\
\hline Hiring costs ( $\%$ of salary) & 28.8 & 12.7 & 21.4 \\
\hline Firing costs (weeks of wages) & 41.2 & 71.2 & 31.3 \\
\hline \multicolumn{4}{|l|}{ D. Registering Property } \\
\hline Number of procedures & 7.0 & 7.0 & 4.7 \\
\hline Time (days) & 137.0 & 109.9 & 31.8 \\
\hline Cost ( $\%$ of property per capita) & 27.2 & 11.6 & 4.3 \\
\hline \multicolumn{4}{|l|}{ E. Getting Credit } \\
\hline Legal rights index & 3.0 & 4.2 & 6.3 \\
\hline Credit information index & 2.0 & 1.3 & 5.0 \\
\hline Public credit registry coverage ( $\%$ adults) & 1.4 & 1.5 & 8.4 \\
\hline Private bureau coverage ( $\%$ adults) & 0.0 & 3.8 & 60.8 \\
\hline \multicolumn{4}{|l|}{ F. Protecting Investors } \\
\hline Disclosure index & 4.0 & 4.4 & 6.3 \\
\hline Director liability indiex & 5.0 & 4.5 & 5.0 \\
\hline Shareholder suits index & 6.0 & 5.2 & 6.6 \\
\hline Investor protection index & 5.0 & 4.7 & 6.0 \\
\hline \multicolumn{4}{|l|}{ G. Paying Taxes } \\
\hline Payments (number) & 94.0 & 40.9 & 15.3 \\
\hline Time (hours) & 576.0 & 336.4 & 202.9 \\
\hline Total tax payable (\% of gross profit) & 57.3 & 71.2 & 47.8 \\
\hline \multicolumn{4}{|l|}{ H. Trading across borders } \\
\hline Documents for export (number) & 12.0 & 8.2 & 4.8 \\
\hline Time for export (days) & 50.0 & 40.0 & 10.5 \\
\hline Cost to Export (US\$ per container) & 1732.0 & 1561.0 & 811.0 \\
\hline Documents for import (number) & 15.0 & 12.2 & 5.9 \\
\hline Time for import (days) & 62.0 & 51.5 & 12.2 \\
\hline Cost to Import (US $\$$ per container) & 2201.0 & 1947.0 & 883.0 \\
\hline \multicolumn{4}{|l|}{ I. Enforcing Contracts } \\
\hline Number of procedures & 47.0 & 38.1 & 22.2 \\
\hline Time (days) & 560.0 & 581.1 & 351.2 \\
\hline Cost (\% of debt) & 45.6 & 42.2 & 11.2 \\
\hline \multicolumn{4}{|l|}{ J. Closing a Business } \\
\hline Time (years) & 3.0 & 2.6 & 1.4 \\
\hline Cost $(\%$ of estate $)$ & 24.0 & 16.0 & 7.1 \\
\hline Recovery rate (cents on the dollar) & 19.4 & 17.7 & 74.0 \\
\hline
\end{tabular}

Source: World Bank. 


\section{A Medium-Term Fiscal Strategy ${ }^{3}$}

\section{A. Introduction}

16. Countries abundant in natural resources face a number of policy challenges, particularly in the fiscal area, relating to sustainability in the management of these resources. The volatility of commodity prices makes it particularly important that such countries pay attention to the debt dynamics of fiscal policy over the medium- to long-term. In addition, the limited amount of natural resources imposes another important challenge for fiscal policy over the medium- and long-term, namely to strike the right balance between spending now and saving for the future when natural resources will be depleted. This chapter examines these key policy issues in the context of the Republic of Congo.

\section{Congo's economic history since the 1970s illustrates the dangers of following a} procyclical fiscal policy in a heavily oil-dependent economy, and not saving a sufficiently large share of current oil revenues to ensure the sustainability of fiscal policy in the medium- and long-run. The limited success of many oil-producing countries in using their oil resources wisely to improve living standards for the average citizen, including Congo's experience in the 1980s, also underscores the importance of adopting a comprehensive medium-term fiscal strategy. The key challenge for Congo's fiscal strategy is the accumulation of sufficient financial assets over time so as to prevent a decline in living standards as the country's oil resources are depleted. This is especially important since oil production in Congo is projected to peak in 2010 and decline thereafter (Figure II.1). Given the existing weaknesses in Congo's public expenditure management system, obtaining the maximum benefits from the utilization of the nation's oil revenues will require that steps also be taken to significantly improve the quality of public spending (see Chapter III).

18. This chapter is organized as follows. Section II provides some background on Congo's past experience with the management of oil resources, including the crisis of the second half of the 1980s. The key elements of a medium-term fiscal strategy to avoid a repeat of such a crisis are outlined in Section III. Section IV concludes.

\footnotetext{
${ }^{3}$ Prepared by Stéphane Carcillo, based on Carcillo, Leigh and Villafuerte (2007).
} 
Figure II.1. Republic of Congo: Oil production, 2000-12

(Thousands of barrels per day)

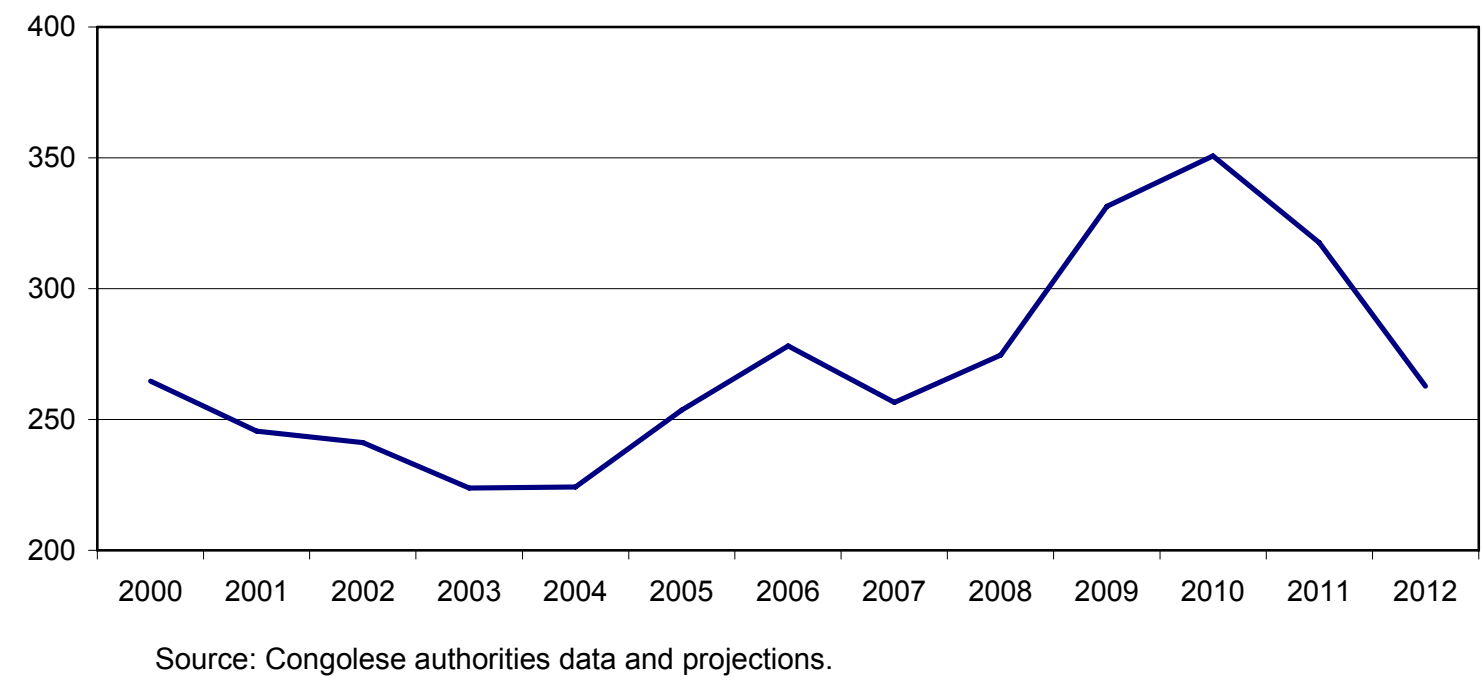

B. Background

19. Congo's economic history since the 1970s illustrates the dangers for macroeconomic stability of following a procyclical fiscal policy in a heavily oildependent economy. The oil boom of the 1970s and early 1980s (Box II.1) encouraged the Congolese authorities to adopt in 1981 an ambitious Five-Year Economic and Social Development Plan, underlying which was an expansionary fiscal policy path (Table II.1, Figure II.2). Government investment rose by an average annual rate of 15 percent in the first half of the 1980s. Even though current expenditure was curtailed, the domestic financial imbalances, which had widened in the second half of the 1970s, continued to deteriorate in the first half of the 1980s. In addition, the country's external indebtedness, which had already grown rapidly in the 1970s and early 1980s to finance domestic investment, doubled between 1980-84 and 1985-89, resulting in an unsustainable debt path.

20. The rapid rise in the public sector during the oil boom years of the early 1980 s, including in the form of large public employment creation, partly provided the seeds for the subsequent long decline in output. The oil bonanza came to an end in the second half of the 1980s, when oil prices declined to an average of $\$ 18$ per barrel during 1986-90 (from an average of $\$ 31$ per barrel during 1981-85). In view of the associated significant decline in oil revenues, the government undertook some fiscal adjustment measures, including in the context of an IMF Stand-By Arrangement launched in August 1986. However, the government's policy response to the terms of trade shock in the second half of the 1980s was slow and limited, relying mainly on cuts in government investment spending and limited structural reforms. As a result, economic activity stagnated, fiscal and external imbalances widened markedly, and the external public debt and debt-service burdens grew to unsustainable levels. In addition, large domestic and external payment arrears accumulated. 


\section{Box II.1. The Oil Sector in the Republic of Congo}

Congo was in 2005 the sixth largest oil producer in sub-Saharan Africa, after Nigeria, Angola, Sudan, Equatorial Guinea and Gabon. This sector is today the country's primary source of economic growth. The country is heavily dependent on its oil sector, which accounts for about half its GDP, and more than 80 percent of government revenues and merchandise exports. According to 2006 estimates by the Oil and Gas Journal (OGJ), Congo has 1.5 billion barrels of proven oil reserves, most of which are located offshore. One of the more recent oil discoveries in 2004 was the onshore M'Boundi field, with proven reserves of 250 million barrels. Based on geological data, undiscovered reserves are estimated at 5.8 billion barrels on a risk-weighted basis. Congo's crude oil types are typically medium and sweet.

Oil production in Congo commenced in the 1950s, and expanded rapidly in the 1980s and 1990s to reach a first peak in 2000. Production started in 1957 from the onshore Pointe Indienne field, which reached a peak output of about 2,500 barrels per day in the mid-1960s. During the 1980s and 1990s Congo's crude production quadrupled, from 65,000 barrels per day in 1980 to an average of 280,000 barrels per day in 2000. Since then production has been falling, largely due to a decline in production at mature fields, and delays in bringing several new fields online. Crude oil production fell from an average of 265,000 barrels per day in 2000 to 224,000 barrels per day in 2004. However, oil production hast started to rebound and will continue to do so over the medium-term as new fields (including the M'Boundi field onshore, and the Moho-Bilondo field offshore starting from 2008) come online and offset declining output at more mature fields. Approximately 35 to 50 percent of the oil produced goes directly to the government and is mostly sold by the national oil company, the SNPC. The rest goes to the international oil partners, based on bilateral oil sharing contracts.

Oil production in Congo is expected to peak in 2010, at over 350,000 barrels per day, and may then fall at a fairly rapid pace thereafter-with important consequences for fiscal oil revenues. The authorities' projections, however, assume annual oil production to be constant from 2012 onwards instead of declining, the assumption being that production from new oil fields could compensate for declining oil production from maturing fields. The authorities' projections may be on the conservative side to the extent that a 'prudence' factor of $\$ 10$ per barrel is deducted from the World Economic Outlook (WEO) oil price projections.

Table II.1. Republic of Congo: Key Fiscal Indicators, 1971-2005

(Percent of GDP, unless otherwise indicated)

\begin{tabular}{|c|c|c|c|c|c|c|c|}
\hline & $1971-1975$ & $1976-1980$ & $1981-1985$ & $1986-1990$ & $1991-1995$ & $1996-2000$ & $2001-2005$ \\
\hline Oil revenues & 4.4 & 9.3 & 22.1 & 11.5 & 12.7 & 17.9 & 23.2 \\
\hline Primary current expenditures & 23.2 & 26.9 & 22.9 & 23.0 & 25.7 & 21.6 & 22.4 \\
\hline Capital expenditures & 4.7 & 5.3 & 20.4 & 4.9 & 1.8 & 6.8 & 7.6 \\
\hline Primary balance & -0.8 & -0.7 & 12.1 & 1.4 & -2.2 & 4.7 & 9.3 \\
\hline Overall balance (including grants) & -4.8 & -6.4 & -6.7 & -10.3 & -12.3 & -8.8 & 2.3 \\
\hline Public and publicly guaranteed external debt & 41.2 & 64.6 & 86.7 & 150.7 & 194.1 & 217.9 & 178.6 \\
\hline \multicolumn{8}{|l|}{ Memorandum item: } \\
\hline Oil price (US\$ per barrel) & 7.1 & 22.3 & 31.2 & 18.0 & 17.9 & 19.7 & 34.1 \\
\hline
\end{tabular}


21. The fiscal imbalances of the late 1980 s were followed by a large devaluation and a significant decline in per capita GDP. Given the magnitude of the macroeconomic imbalances in the late 1980s and early 1990s, it became clear by 1993 that fiscal adjustment alone would not be sufficient to restore external competitiveness because nominal domestic prices showed considerable downward rigidity. In addition, the onset of civil war in Congo in 1993-94 further complicated macroeconomic management. The CFA franc was devalued by 50 percent in January 1994 to restore competitiveness and boost exports. As a result, per capita GDP declined from its peak of US\$1,390 in 1984 to about US\$980 in 1995 (both in constant 2000 US dollars), resulting in a large increase in the incidence of poverty (see below). Over the following decade, successive economic programs supported by the IMF went off track, owing to further political instability, weak fiscal discipline, and insufficient resolve to implement structural reforms, especially in the oil sector.

\section{In summary, Congo's lack of a fiscal strategy in the 1980s consistent with the} preservation of the nation's oil wealth resulted in unsustainable growth, and an eventual sharp decline in living standards. Even though Congo's human development index is higher than the average for sub-Saharan Africa and for both oil- and non-oil producing PRGF-eligible countries, it has been falling steadily since 1985 (Figure II.3). Moreover, poverty remains widespread: a recent household survey, completed in early 2006, shows that 42 percent of households and 51 percent of individuals live below the poverty line, and that pockets of poverty are equally distributed in urban and rural areas. Over the past decade Congo has also fallen significantly behind other developing countries, including oil-producing PRGF-eligible countries, in per capita GDP growth performance. 
Figure II.2. Republic of Congo: Key Fiscal Indicators, 1971-2005 (Percent of GDP)
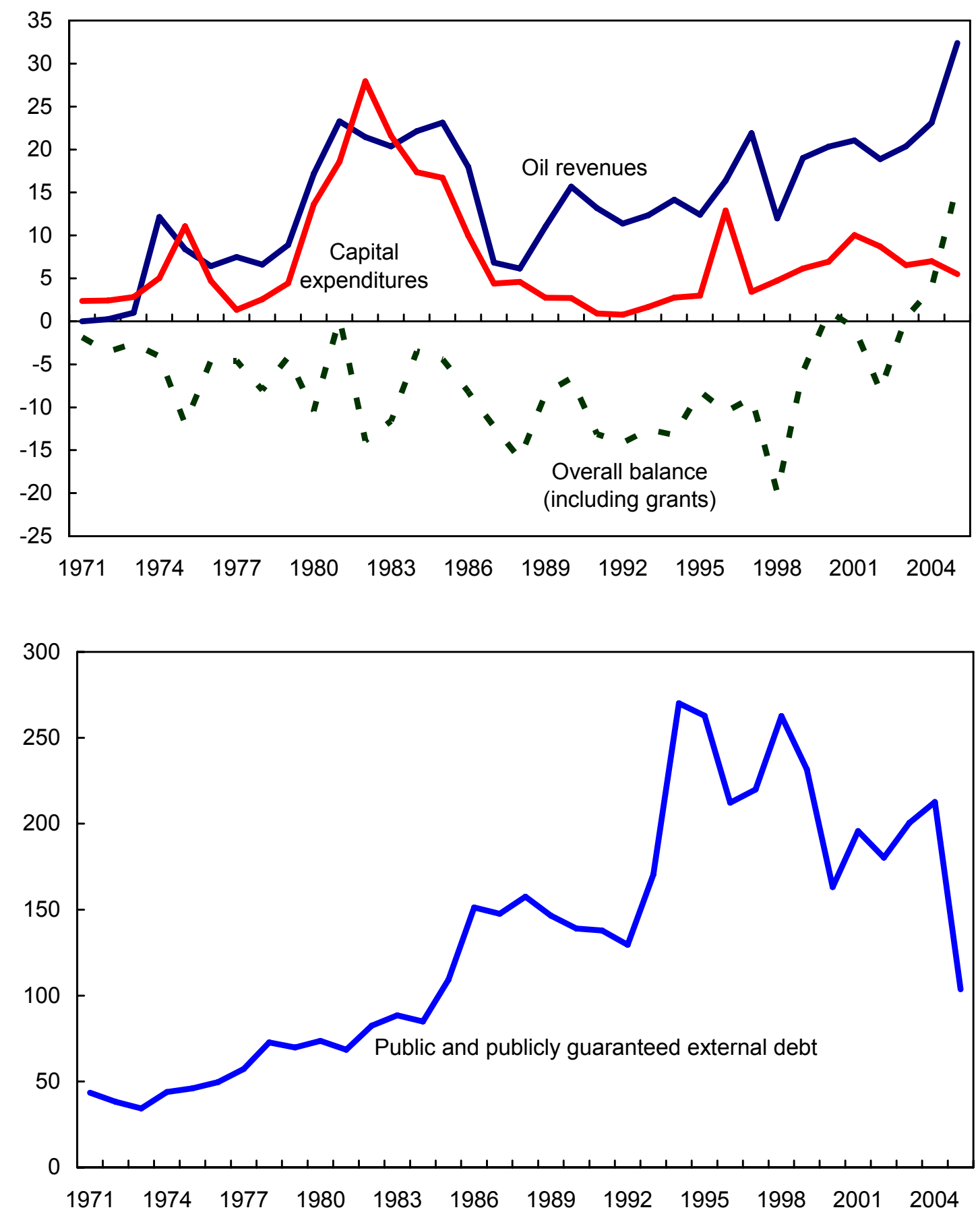

Source: Congolese authorities, Fund staff estimates and World Bank World Development Indicators. 


\section{Key Elements of a Medium-Term Fiscal Strategy}

\section{Preserving Oil Wealth for Fiscal Sustainability}

\section{A key issue for an oil-producing country like Congo is not only whether a} particular fiscal policy stance is sustainable in terms of its debt dynamics, but also whether it is sustainable in terms of preserving the nation's oil wealth so as to prevent a decline in living standards when oil production declines. Using the 'primary gap' approach, a higher level of GDP growth will, ceteris paribus, automatically make a country's fiscal position more sustainable. From a wider perspective, however, the opposite may be true if the higher output growth results from a faster rate of natural resource depletion which threatens the long-term sustainability of per capita real income (and, hence, living standards) in the future.

\section{For oil-producing countries (OPCs) with large exhaustible oil resources, it is} appropriate for the analysis to incorporate the following three considerations:

$>$ First, the projection period should be long enough to consider whether the debt-toGDP ratio is expected to stabilize at a level that can be maintained indefinitely after oil resources are exhausted.

$>$ Second, the exhaustible nature of oil resources raises important intergenerational distributional issues, which can be best taken into account in expressing spending as a percentage of nonoil GDP, which reflects the increasing needs of the government in the context of a growing economy.

$>$ Third, the nonoil primary fiscal balance (that is, total nonoil revenue less nonoil noninterest expenditure) provides a clearer indicator of the fiscal policy stance for OPCs because it filters out fluctuations in revenue due to swings in international oil prices. ${ }^{4}$

The analysis that follows incorporates these three considerations.

\footnotetext{
${ }^{4}$ As oil revenue is exhausted, the nonoil fiscal balance converges towards the overall primary balance used in traditional DSA analyses.
} 
Figure II.3. Republic of Congo: Human Development Index and Growth
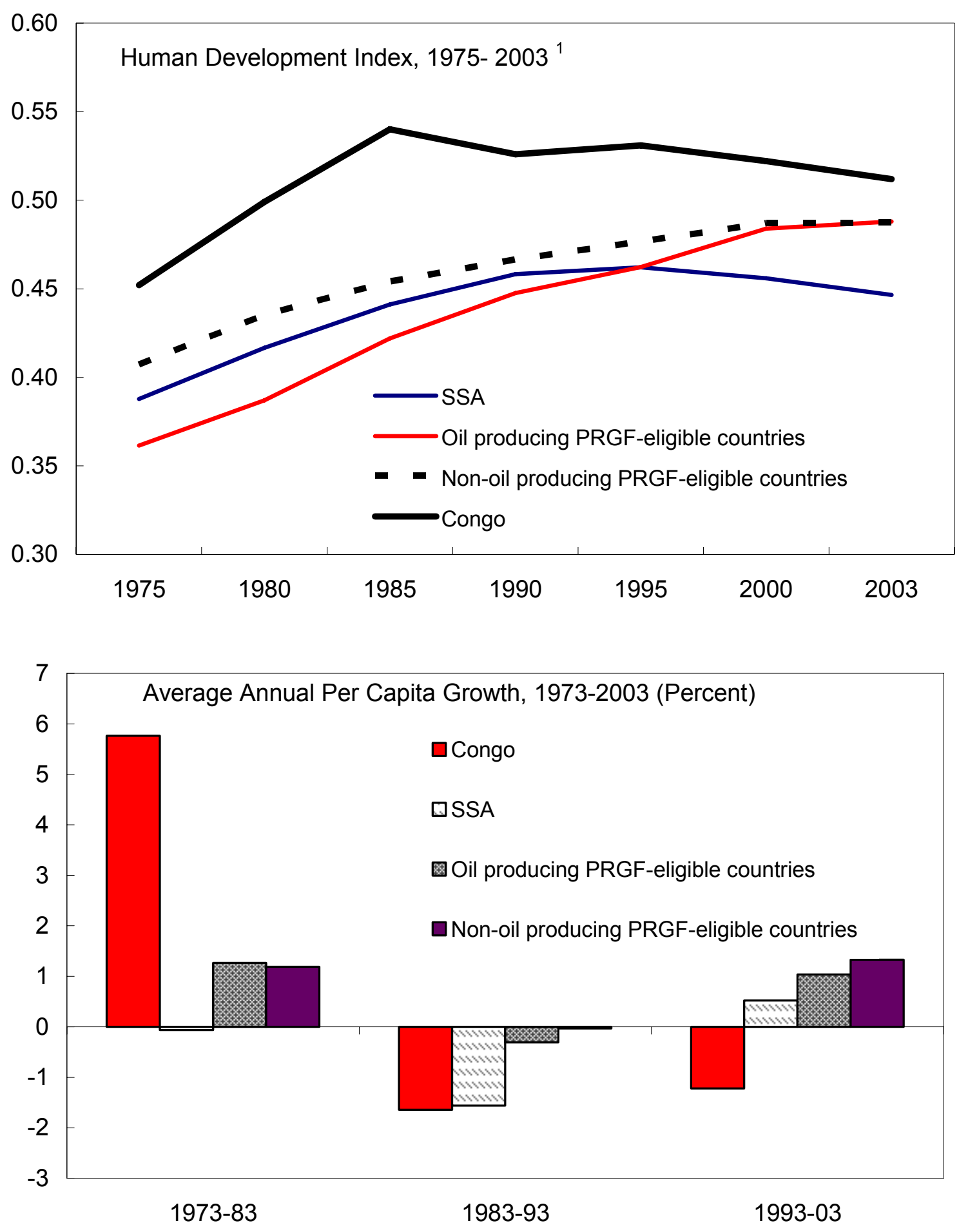

Sources: IMF, World Economic Outlook, and United Nations Development Program.

${ }^{1}$ Includes only countries for which data are available for all periods. 
25. Based on this methodology developed by Leigh and Olters (2006) for Gabon, we propose the estimation of a sustainable primary balance expressed as a percentage of nonoil GDP that takes into account oil resources depletion and allows for progressive adjustment. Intertemporal optimization with habit formation lies at the core of the paper's analysis. According to the permanent income hypothesis, the optimal policy is defined as a path of government spending that smoothes consumption over time and is consistent with the government intertemporal budget constraint. The optimal spending level depends on a number of factors, among them the future path of oil and non-oil tax revenues and the real interest rate. Expenditure is measured as a share of nonoil GDP. ${ }^{5}$

\section{The analysis in this paper goes one step further and allows for the realistic} possibility of negative growth-adjusted interest rates during a temporary period of rapid catch-up growth. This approach differs from a number of studies that assume that the real interest is always larger than the growth rate. Instead, we assume that the interest rate and the growth rate of nonoil GDP can vary over time, but that both rates are constant in the long-run and that the interest rate will be then over the growth rate.

27. Under these assumptions, the optimal policy is to set spending equal to permanent income, i.e., to the return on the present discounted value of all future oil and nonoil revenues. The full-fledged model underlying our simulations is presented in Carcillo, Leigh, and Villafuerte (2007). The calibration of the model is presented in Box II.2.

\section{Results and Sensitivity tests}

28. Three main results emerge from the simulation of the model, starting from the 2005 non-oil primary deficit level of 29 percent of non-oil GDP $^{6}$ (Table II. 2 presents the results):

First, the current level of the non-oil primary deficit is not sustainable. If the nonoil primary deficit is maintained at the 2005 level of 29 percent of nonoil GDP, debt will eventually explode. Under the baseline assumptions, the permanently sustainable nonoil primary deficit (PSNOPD) is estimated to be about 13 percent of nonoil GDP.

\footnotetext{
${ }^{5}$ Choosing to measure expenditure in real terms instead of as a share of nonoil GDP would imply, under standard assumptions, a constant path of government spending in real terms out of net government wealth (whereas expenditure would increase in real terms when using the share-of-non-oil-to-GDP criterion). Assuming a positive rate of non-oil GDP growth, this criterion would also imply the need for a continuous adjustment in the non-oil primary deficit in percent of non-oil GDP until the oil wealth is depleted in real terms.

${ }^{6}$ The nonoil primary deficit considered here includes foreign-financed capital investment, which is excluded instead in the definition in the accompanying Article IV staff report.
} 


\section{Box II.2. Calibration of the model for the Republic of Congo}

\section{The following assumptions were made to establish the baseline projection for future real oil revenue:}

$>$ The baseline projection for oil prices is based on the February 2007 World Economic Outlook (WEO) projections for 2007-12. Accordingly, the oil price is projected to average $\$ 64$ per barrel over the 2008-12 period. In the long run, the price will stabilize at $\$ 63$ per barrel.

As for future oil output, it as assumed that Congo has oil reserves of at least 2 billion barrels, somewhat higher than the current proven reserves. Annual oil production is expected to decline from its current level by about one-half in twenty years and to be exhausted in about thirty years (Figure II.3).

$>$ The paper assumes that the long-run oil tax rate will be 47 percent in the baseline scenario, 41 percent in the low price scenario, and 53 percent in the high price scenario, consistent with the average oil sharing contract for Congo. The non-oil tax rate is kept constant at the 2005 level of 18 percent.

$>$ It is also assumed that the long-run real interest rate equals 4 percent, below the current 4.4 percent paid on debt which is supposed to hold for another five years (2006-11).

$>$ The non-oil growth rate, $\gamma$, is set at 2 percent in the long-run, below the current 6.5 percent which reflects a catch-up period, and is supposed to hold during 2006-11, and decline to its long-run level over the following five years.

\section{Second, the optimal path involves spreading the bulk of the adjustment over a} period of five years. Under baseline parameters, the nonoil deficit would decline by 9 percentage points to 20 percent of non-oil GDP by 2011 - close to 60 percent of the total adjustment required. Figure II.4 shows that the substantial overall primary surpluses that would materialize during this period - needed to pay off debt and accumulate sufficient financial assets. From a fraction of the returns on those assets, it then finances the non-oil deficit in the post-oil period. By contrast, a strategy of stabilizing net debt at a positive level would not be consistent with running a permanent deficit in the post-oil era. As oil reserves are exhausted, the primary surpluses decline and converge to the permanently sustainable level of 13 percent of GDP in 2026, some years before oil revenue is assumed to dry up. 
Figure II.4. Republic of Congo: Optimal Fiscal Adjustment Path (Baseline Assumptions, 2005-60)

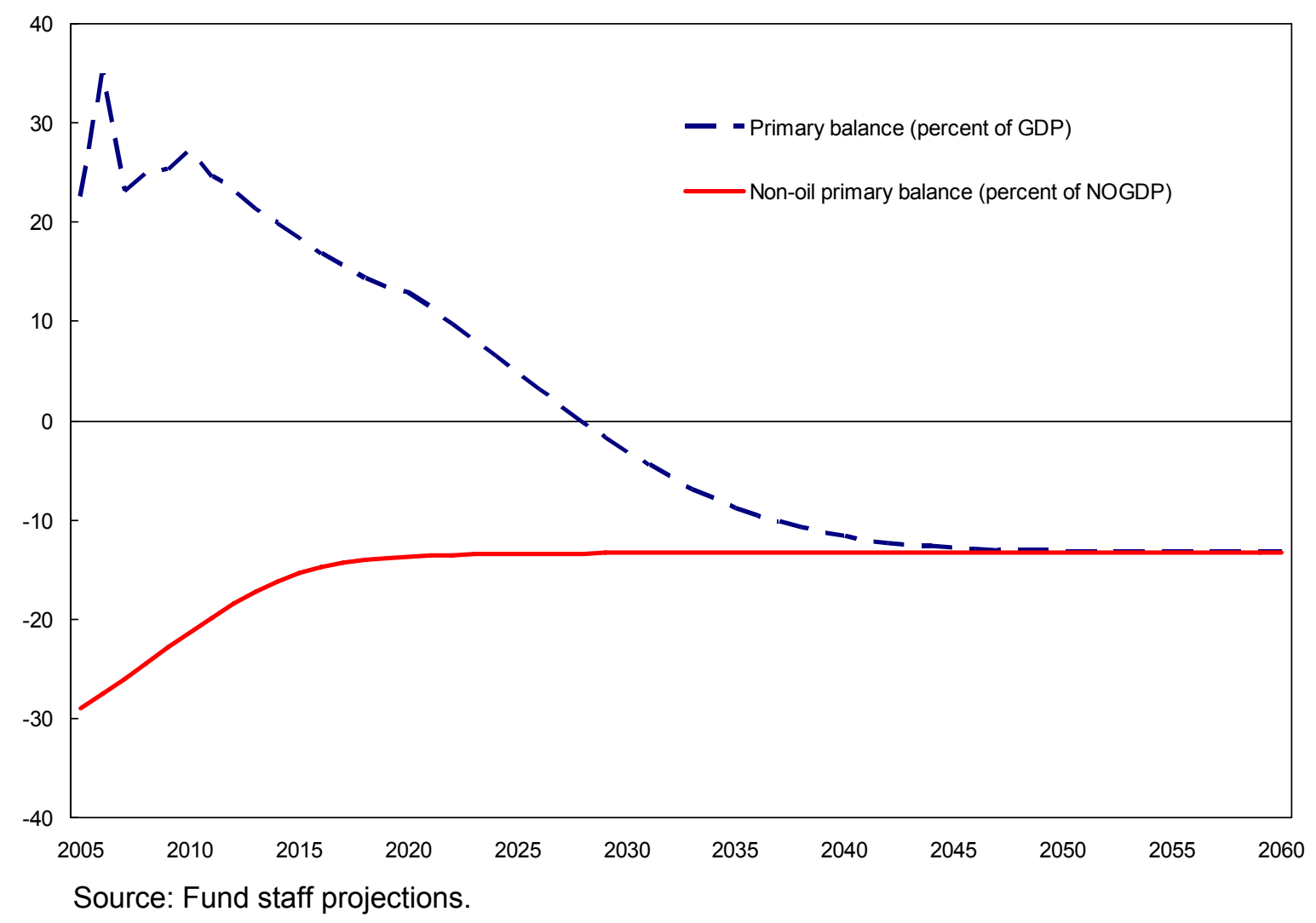

\section{Third, the level of the PSNOPD depends on the speed of adjustment. Figure II.5} shows how the estimated PSNOPD varies for different speeds of adjustment. For example, while the baseline scenario is consistent with completing more than 60 percent of the adjustment within 5 years, extending this period to 20 years would halve the PSNOPD to only 8 percent of nonoil GDP. 
Figure II.5. Republic of Congo: Tradeoff Between Adjustment Speed and Estimated PSNOPD

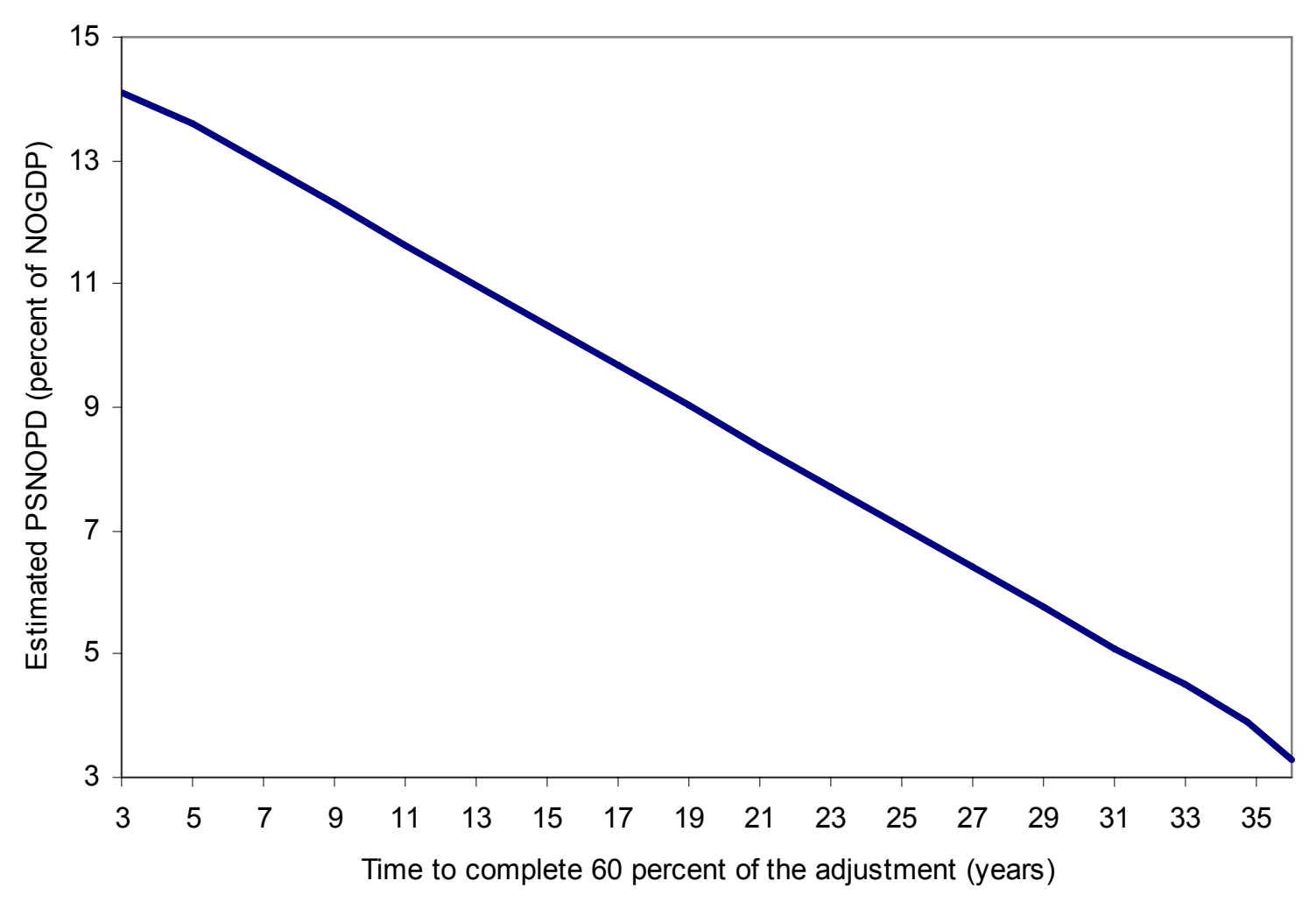

Source: Fund staff projections.

29. The result that the $\mathbf{2 0 0 5}$ deficit is unsustainable is robust, even under the most favorable assumptions, based on a range of sensitivity tests on all the parameters in the model (Table II.2). For example, even if total reserves were to increase by 30 percent relative to the baseline, the sustainable nonoil deficit would rise to 16 percent of nonoil GDP, still well below the actual 2005 level. If the authorities succeeded in raising the tax take on oil GDP by 5 percentage points under the baseline assumptions, the PSNOPD would increase to 15 percent of nonoil GDP, also well below the current level. 
Table II.2. Republic of Congo: Sensitivity Analysis

\begin{tabular}{|c|c|}
\hline Scenario & Result \\
\hline Baseline parameters & 13.4 \\
\hline \multicolumn{2}{|l|}{ Sensitivity tests } \\
\hline \multicolumn{2}{|l|}{ Long-run Brent oil price (baseline $=\$ 61 / \mathrm{bbl})^{1}$} \\
\hline Higher oil prices ( $\$ 80 / b b l)$ & 18.1 \\
\hline Lower oil price $(\$ 40 / b b l)$ & 10.3 \\
\hline \multicolumn{2}{|l|}{ Oil reserves (baseline $=100$ ) } \\
\hline Higher oil reserves (130) & 16.0 \\
\hline Lower oil reserves $(70)$ & 8.9 \\
\hline \multicolumn{2}{|l|}{ Effective oil tax take (baseline $=47$ percent) } \\
\hline Higher oil tax take (+5 ppt) & 15.0 \\
\hline Lower oil tax take (-5 ppt) & 11.7 \\
\hline \multicolumn{2}{|l|}{ Long-run real interest rate (baseline: $r=4.0)^{2}$} \\
\hline Higher $r=4.5$ & 16.0 \\
\hline Lower $r=3.5$ & 10.3 \\
\hline \multicolumn{2}{|l|}{ Long-run growth rate (baseline: $y=2.0)^{2}$} \\
\hline Higher $y=2.5$ & 10.0 \\
\hline Lower $y=1.5$ & 16.7 \\
\hline \multicolumn{2}{|l|}{ Habit strength (baseline: $\alpha=0.7$ ) } \\
\hline No habits $(\alpha=0)$ & 14.0 \\
\hline Stronger habits $(\alpha=0.8)$ & 12.8 \\
\hline Weaker habits $(\alpha=0.6)$ & 13.6 \\
\hline
\end{tabular}

Source: Fund staff projections.

${ }^{1}$ The Congolese oil price is lower due to the quality discuount.

${ }^{2}$ Long-run values, which hold from 2016 onwards.

30. Overall, the above analysis indicates that a larger share of oil revenues should be saved for future generations than is being contemplated at the present time. In this context, a prudent fiscal policy would target a steady rise in the nonoil primary balance, from a projected deficit of 44 percent of nonoil GDP in 2006, moving towards a deficit of about 15 percent by 2015 , representing most of the adjustment required to reach the sustainable level of 13 percent of nonoil GDP by 2025.

31. A sensible fiscal policy would also require sound judgment regarding the absorptive capacity of the economy to accommodate higher government spending at the technical, institutional and infrastructural levels. Given the lack of infrastructure in the 
country, there is a need for productive investment in physical infrastructure, health, and education, particularly in the context of meeting the MDGs. At the same time, attention needs to be paid to technical, institutional, and infrastructural capacity constraints and bottlenecks that are likely to be faced in the context of a rapid and overambitious expansion of government spending in these sectors, thereby generating inflationary pressures. It is thus critical that efforts should continue to improve the quality and efficiency of capital expenditures, including through the adoption and implementation of a new public investment management system. As Takizawa et al (2004) note, when the efficiency of government spending increases over time, in countries such as Congo which suffer not only from poor infrastructure but also from weak institutions, there are likely to be greater advantages to postponing spending to when it can be used more effectively.

\section{Conclusion}

\section{In assessing Congo's fiscal-policy options during the remaining years of oil} production, this paper reaches three main conclusions. First, Congo's current non-oil primary deficit is not sustainable. The permanently sustainable non-oil primary deficit, estimated at 13 percent of nonoil GDP, is well below the level of 29 percent or 44 percent of nonoil GDP in 2005 and 2006, respectively. Second, the presence of habit formation implies that the optimal policy involves spreading the bulk of the adjustment over a number of years, rather than conducting the single, abrupt adjustment that standard permanent income models without habits prescribe. Third, there is a tradeoff between slower adjustment and a lower long-run sustainable nonoil deficit. Uncertainty regarding future economic conditions would provide a risk-averse policymaker with precautionary motives for front-loading the adjustment. Finally, the quality of public expenditure should improve over time as public financial management is enhanced and an appropriate growth and poverty-reduction strategy developed, providing greater assurance that government spending could generate adequate growth and social pay-offs. 


\section{References}

Stéphane Carcillo, Daniel Leigh, and Mauricio Villafuerte, 2007, "Catch-Up Growth, Habits, Oil Depletion, and Fiscal Policy: Lessons from the Republic of Congo", IMF Working Paper No. 07/80, International Monetary Fund, Washington, D.C., forthcoming.

Daniel Leigh and Jan-Peter Olters, "Natural-Resource Depletion, Habit Formation, and Sustainable Foscal Policy: Lessons from Gabon", IMF Working Paper WP/06/193, International Monetary Fund, Washington, D.C., August 2006.

Hajime Takizawa, Edward Gardner, and Kenichi Ueda, “Are Developing Countries Better Off Spending Their Oil Wealth Upfront?”, ”, IMF Working Paper WP/04/141, International Monetary Fund, Washington, D.C., 2004. 


\section{Strategy to Improve Public Financial Management ${ }^{7}$}

\section{A. Introduction}

\section{This chapter discusses a strategy to improve public financial management} (PFM) in Congo. Recent assessments of the PFM system in Congo point out to weaknesses in several areas, including budget preparation and execution, transparency, long-term planning, and overall credibility. With little headway made in addressing these weaknesses, there is a need to accelerate the momentum of this reform process to improve the quality of spending, enhance the impact of public spending on growth, and reduce poverty.

\section{Strengthening PFM is a prerequisite for scaling up spending to meet the MDGs}

by $2015 .{ }^{8}$ A sound fiscal environment and framework are crucial in making the best use of the resource allocated to poverty reduction. In contrast, spending in the context of a nontransparent and ineffective budgeting system is less likely to have any social impact: expenditure control will be weak, public procurement biased, and goods and services not fully delivered. Ultimately, the resources will thus not be used as originally intended.

\section{PFM reforms in Congo are particularly relevant in the current context of high} oil prices. A significant portion of the rise in oil prices is expected to be long-lasting and oil revenue will continue to be the first source of financing of public spending on priority and economic and social goals. In this context, the current weak institutional framework limits the ability to address the nation's development needs effectively. Moreover, the additional resources secured through debt relief under the Enhance HIPC Initiative and MDRI will need to be channeled to alleviate poverty through rigorous and transparent budgetary processes.

\section{Congo's real prospects of securing significant oil revenues to fight poverty while} maintaining a sound macroeconomic framework conducive to lasting growth are strong incentives for the authorities to step up their efforts to strengthening their PFM system. The authorities recognize that weaknesses in their PFM system impedes their ability to address the needs of the population and the fight against poverty; raises serious governance and issues; and fails to attract budget support. They also are aware that a weak PFM system does not contribute to transparency in managing oil resources in the face of a greater push for accountability from both civil society and international community. The country has started confronting the PFM issues but progress has been limited so far, partly reflecting weak

\footnotetext{
${ }^{7}$ Prepared by Abdelrahmi Bessaha and Yaya Moussa, with input from Jean-Pierre Nguenang.

${ }^{8}$ In order to meet the MDGs by 2015, Congo will need to spend more resources in the health and education sectors. A critical spending mass is required to start impacting poverty indicators. This highlights the importance of efficient resource management, including better budget preparation and control, and a medium-term framework for setting expenditure priorities.
} 
administrative and technical capacity as well as political economy considerations. This in turn, hinders the government's ability to design and follow through reforms.

37. The paper is organized as follows. Section B. provides a summary of various recent assessments of the quality of the Congo PFM system. Section C. reviews the key areas of PFM where there is a need to accelerate the momentum of reform to set the process on a irreversible track so that the country benefit from better management of public resources, in particular the oil windfall. Section D. discusses the reform priorities in the context of a well sequenced program and reviews the technical and institutional challenges. Section E. concludes.

\section{B. An Assessment of the Quality of the PFM System}

38. The quality of Congo's PFM system has been discussed in several recent reports. Below is a summary of the key findings.

$>$ The Public Expenditure and Financial Accountability (PEFA) assessment ${ }^{2}$ confirmed the poor performance at end-2005 of Congo's PFM system across the board in key areas of budget preparation, execution, and control. PEFA attributed a median score of $2.5-$ 3.0 in these areas, compared with the norm of international good practice of 4.0;

$>$ The World Bank Country Policy and Institutional Assessment (CPIA) further confirms Congo's weak PFM system, especially as regards comprehensiveness and credibility of the budget, effectiveness in managing revenues and expenditures, and timeliness, and accuracy in fiscal reporting offers (Figure III.1). The CPIAS offers a similar rating than PEFA, with scoring ranging from 2-3.

$>$ The forthcoming joint World Bank/IMF report on progress toward meeting the completion point triggers under the Enhanced HIPC Initiative reiterates the weak state of the current PFM system, reviews progress so far after a year and confirms the need to accelerate reforms in key areas, including budget planning and execution, public investment management, and transparency in the management of oil resources.

\footnotetext{
2 PEFA is a partnership between the World Bank, the European Commission, the UK's Department for International Development, the Swiss State Secretariat for Economic Affairs, the French Ministry of Foreign Affairs, the Royal Norwegian Ministry of Foreign Affairs, the International Monetary Fund and the Strategic Partnership with Africa.
} 
Figure III.1. Republic of Congo: Assesment of the Quality of the Public Financial Management System, $2006^{1}$

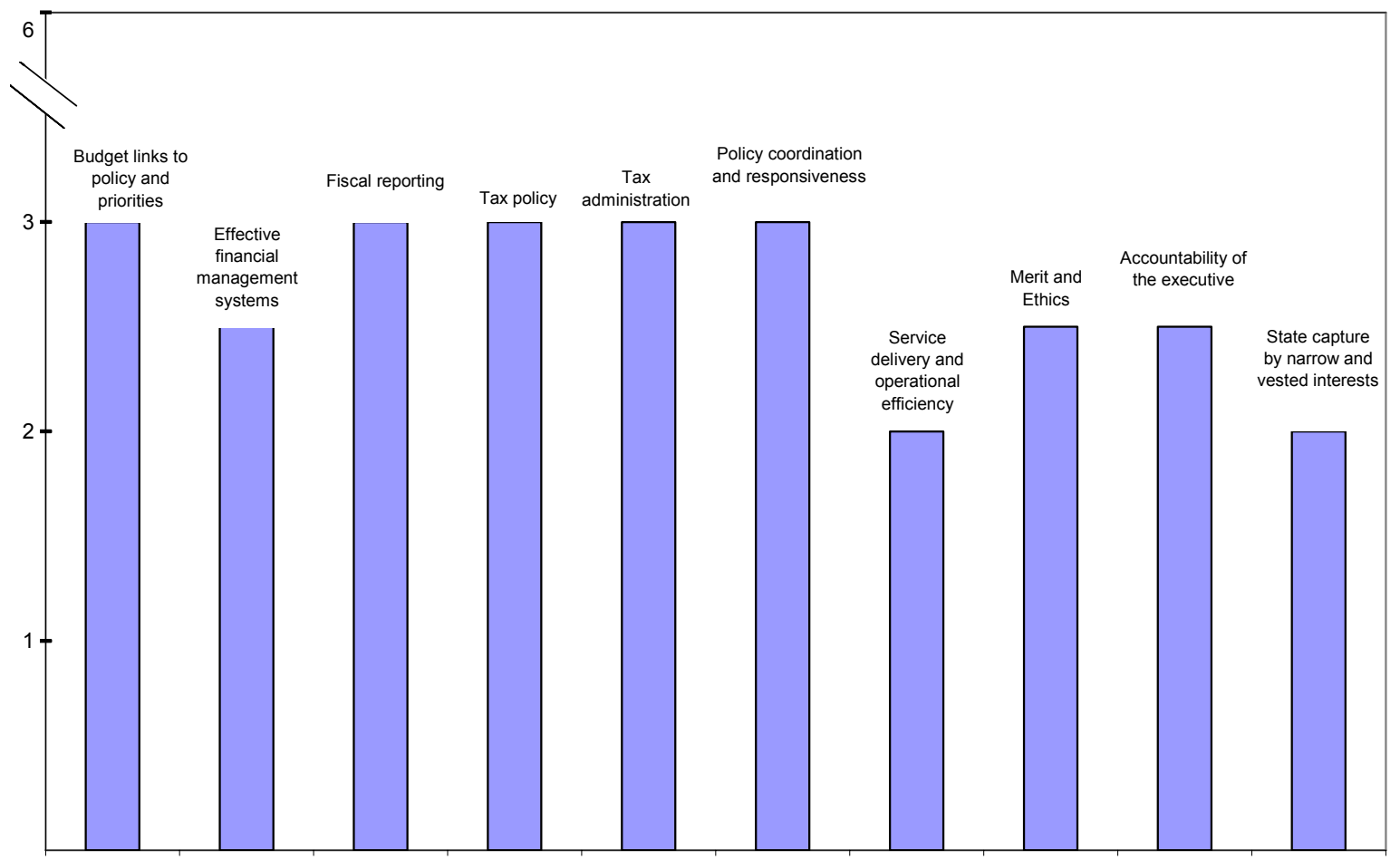

Source: World Bank, Country Policy and Institutional Assessment, 2006.

${ }^{1}$ Scale: scores are from 1 (lowest) to 6 (highest)

\section{Recent technical assistance reports from the IMF and the World Bank further} underscore the significant challenges of reforming PFM. ${ }^{9}$

39. The broad conclusion that can be drawn from these reviews is that Congo's PFM is weak, overall progress is slow, and the challenges ahead significant. This is attributable to various reasons, including technical and political economy considerations. These constraints are likely to continue in the months ahead, calling for a sustained technical assistance support from the donor community and strong ownership on the side of the authorities.

\section{Key Public Financial Management Issues}

40. This section identifies the key PFM priorities. These priorities aim at strengthening: (i) the allocation of public resources on projects with the highest impact on growth, employment creation, and poverty reduction; (ii) the quality of public spending; (iii)

\footnotetext{
${ }^{9}$ IMF: Report on Functional Budget Classification (August 2006); and World Bank: (i) PEFA Report, June 2006; (ii) Public Procurement report, June 2006; and (iii) CIFA report (June 2006).
} 
the transparency of the budgetary process; and (iv) good governance in public administration.

41. A sound PFM system is one that meets the following dimensions: (i) credibility in the sense that the budget is realistic and is implemented as intended; (ii) comprehensiveness and transparency to ensure on one side that the budget and the fiscal risk oversight are comprehensive, and on the other side that fiscal and budget information is readily available to the public; (iii) policy-based budgeting to ensure that the budget is prepared consistent with overall government policy priorities; (iv) predictability and control in budget execution, implying that the budget is implemented in an orderly and predictable manner and reviewed through well-defined mechanisms enabling the exercise of control in the use of public funds; (v) transparent accounting, recording, and reporting, ensuring that adequate records and information are produced, maintained and disseminated to meet decision-making control, management, and accountability; and (vi) external scrutiny and audit calling for the independent review of public administration.

\section{The credibility of the budget}

42. The credibility of the budget in Congo is arguably at stake. Performance in terms of budget credibility is assessed through a set of indicators, including deviations of revenue and expenditure outturns from originally approved targets as well as the size and the monitoring of expenditure payment system. There is evidence of: (i) customs collections below expectations; and (ii) very tentative expenditure costing especially for government consumption and investment projects. Also, large open-ended government contingent liabilities have built up in the energy sector, particularly at the national oil refinery (CORAF). Another indication of weak credibility has been the accumulation of external and domestic payment arrears. There are some efforts to improve budget preparation, as the authorities are now basing their budgetary projections on the macroeconomic assumptions (on growth, inflation, exchange rates, and oil prices) discussed with Fund staff in the context of program reviews. Yet, this is a starting process that needs to be pursued vigorously.

\section{Policy-based budgeting}

\section{The budget process in Congo reflects a lack of overall strategic planning and is} not anchored to other economic processes. This important criterion for the soundness of the PFM system is assessed through two indicators: (i) participation in the annual budget process; and (ii) a multi-year perspective in fiscal planning. The present PFM system fails on both. First, there are discrepancies between the budget and the other government policy documents (such as the interim poverty reduction strategy paper (I-PRSP), and the three-year investment plans), suggesting a loose connection between the budget and other processes, and a disconnect in setting priority spending across government agencies. Second, the authorities have yet to establish a multi-year fiscal framework, expenditure policy, and budgeting. In particular, it is essential that public investment planning be discussed and 
presented several years in advance, and consistent with long-term infrastructure and development goals.

\section{Predictability and control in budget execution}

44. Predictability and control in budget execution are essential to the soundness of a PFM system. The main indicators include transparency in taxpayers' obligations and liabilities; an effective tax assessment system; predictable resources for spending commitments; internal audits and mechanisms for spending controls. All these areas display weaknesses, as illustrated by (i) a discretionary application of the tax code, which encourages fraud; (ii) discretionary negotiation of customs duties; ${ }^{4}$ (iii) inefficiencies in tracking and fighting fraud and evasion, as result of the slow introduction of a single taxpayer identification number; and (iv) the systematic recourse to spending outside the normal spending process. ${ }^{5}$ The latter deficiency is facilitated by the lack of expenditure tracking system as well as the absence of coordination between the Budget Directorate and the Treasury, and between the Budget Directorate and the Ministry of Planning, which considerably weakens the budget process, compromises transparency, execution, and accountability, and further complicates cash management. At the same time this provides the grounds for arrears accumulation and corruption, while increasing the cost of government procurement, as suppliers request advance payments and frequently overcharge to offset payment uncertainties. Procurement procedures also need to be tightened; the two national committees that are supposed to provide oversight over public tendering are inactive.

\section{Comprehensiveness and transparency}

\section{Congo's PFM system fails with regard to comprehensiveness and transparency} requirements, as gauged by indicators like budget classification, extent of unreported government operations, transparency of inter-governmental operations, public access to key fiscal information, and oversight of aggregate fiscal risk from other public entities. The failure has been facilitated by the lack of an operational functional classification of the budget. This has facilitated misallocation within line ministries (Table III.1). In addition, it is estimated that more than 50 percent of spending for goods and services in the budget are currently unallocated. Any sound functional analysis of the budget would be pointless with such a large share of unallocated spending, including within ministries. The

\footnotetext{
${ }^{4}$ In 2005, the customs administration collected CFAF 43 billion and granted exonerations totaling CFAF 108 billion, of which CFAF 91 billion to the private oil companies alone.

${ }^{5}$ Originally intended for urgent expenditures, the procedure known as " paiements par anticipation" (PPAs) is widely used for regular transactions. While some of these PPAs are authorized by the Directorate General for Budget (DGB) and the Financial Comptroller Budget before payment is made, all too often, these transactions are settled by the Treasury makes payment without informing the DGB.
} 
classification of spending as transfers is also to be reviewed. Current transfers often include subsidies to the oil sector, or amounts that actually serve to finance public investments.

Table III.1. Republic of Congo: Evaluation of Unallocated Appropriations in the Ministries Spending on Goods, 2005

\begin{tabular}{|c|l|r|r|r|}
\hline \multicolumn{1}{|c|}{$\begin{array}{c}\text { Ministry } \\
\text { Code }\end{array}$} & \multicolumn{1}{|c|}{ Heading } & \multicolumn{1}{|c|}{$\begin{array}{c}\text { Unallocated } \\
\text { appropriations to } \\
\text { executive offices of } \\
\text { ministries }\end{array}$} & $\begin{array}{c}\text { Total amount of } \\
\text { appropriations to } \\
\text { the ministries }\end{array}$ & $\begin{array}{c}\text { Percentage of } \\
\text { appropriations } \\
\text { managed by } \\
\text { ministers' executive } \\
\text { offices }\end{array}$ \\
\hline 33 & Communication & 280 & 400 & 70.0 \\
\hline 35 & Planning & 393 & 792 & 49.5 \\
\hline 39 & Energy and water & 172 & 324 & 53.0 \\
\hline 54 & $\begin{array}{l}\text { SMEs and small-scale } \\
\text { industry }\end{array}$ & 135 & 226 & 59.7 \\
\hline 61 & $\begin{array}{l}\text { Primary and secondary } \\
\text { education and literacy }\end{array}$ & 3,198 & 10,715 & 29.8 \\
\hline 63 & $\begin{array}{l}\text { Culture and arts with } \\
\text { responsibility for } \\
\text { tourism }\end{array}$ & 228 & 399 & 58.1 \\
\hline 65 & $\begin{array}{l}\text { Youth rehabilitation and } \\
\text { sports }\end{array}$ & 228 & 392 & 80.3 \\
\hline 71 & Health and population & 7,884 & 9,807 & 5.1 \\
\hline
\end{tabular}

Source: Annex to the 2006 budget.

46. The authorities have started addressing some of these issues. Recent efforts have resulted in: (i) the assignment of a functional classification code to each line item of the common charges and unallocated ministry envelopes in the 2006 budget and (ii) the recording under the appropriate categories in the economic classification of a significant share of unallocated common charges initially envisaged in the draft 2007 budget. The next step will be to press ahead with these efforts, by: (a) shifting a significant share of the unallocated envelopes of the executive offices of the ministries to the directorates general; and (b) distributing the centrally managed common charges across the ministries. It is internationally accepted that each country's budget may contain some unallocated appropriations or a fiscal planning reserve to meet contingencies. Nevertheless, the level of the planning reserve should not exceed 3 percent of the primary current budget, defined as the total budget minus the stabilization fund, payments on public debt, and domestically and externally funded capital expenditure. 


\section{Accounting, Control and Reporting Systems}

\section{Comprehensive and accurate reporting is the first step to establish}

accountability for the use of public funds. With fragmented reporting, the budget fails to provide a comprehensive view of sectoral spending. Data is weak regarding (i) capital projects (detailed information on cost, financing sources, and implementation progress remain partial, yearly reports are not always consistent from one year to the other, public investment plans comprise a lot of spending for the equipment of spending, and little information on the few undergoing large projects): also, there is no reporting on budget execution by individual ministry on a cash basis, and Treasury provides only aggregated spending data; (ii) transfers to public companies such as SNPC, SOCOTRAM and especially CORAF, with a sizable amount of unspecified outlays (common charges). Furthermore, the authorities are not submitting on a regular basis to parliament the official financial report of the government (the loi de règlement). Of equal concern is the lack of institutional oversight of public expenditure. The Inspection Generale des Finances and the Ministry of State Control are not monitoring compliance with financial regulations, as they both lack funding. The newly created Cour des Comptes, has yet to carry out audits of the various government institutions, as it is not yet operational. The flow of funds tables are not produced on a timely basis and submitted along with information on the specific expenditure. There are also delays in completing the consolidated treasury balance, a useful tool that enables running a consistency test among budget execution data.

\section{The External Scrutiny and Audit}

48. The credibility of the budget in Congo is arguably at stake when assessed against the legal and institutional setting in place. The foundations of the legal and institutional setting for Congo's PFM are provided by the Organic Law on Budget Laws and the Government Accounting Regulations of 2000. There is no evidence that the legal framework is not adequate for ensuring a credible budget process. Notwithstanding the existence of sound budgetary rules and procedures, the budget process is distorted by the political process and governance considerations which render elusive the separation of powers between the executive and the legislative branches on budget matters, as enshrined in the 2002 Constitution. Draft budget laws are not submitted to Parliament on time and expenditure overruns are common place. This, in turn, leaves little time for Parliament to examine and vote on the budget, further eroding the legislative branch authority while causing repeated delays in voting on both the budget laws and the budget review laws. As a result, Parliament retains little control over the budget. Further, even other institutions which are stakeholders in this process, such as the National Audit Office, cannot perform their functions as they are poorly equipped, understaffed, and not appropriately tasked with external budget control. 


\section{Transparency and Management of Oil Resources}

49. Congo is experiencing difficulties in managing oil revenues in a transparent fashion. A recent audit report indicates pointed out to (i) weaknesses and limitations of the government institutions involved in the awarding process; (ii) a lack of regulations to implement the existing Hydrocarbon Code, in particular the lack of procedures for the awarding of contracts under competitive conditions and the selection process in awarding contracts to local and foreign private operators; (iii) an absence of clarity regarding the role that SNPC should play as holder of mining rights in the process of negotiation of new contracts and its participation in setting up of associations with private operators; (iv) a potential for conflict of interest concerning the sector and SNPC in view of the current institutional set up; (vi) a lack of effective controls over the enforcement of appropriate evaluation, reporting and filing procedures; and (vii) deficiencies in the Code of Penal Law as it doesn't cover conflicts of interest in the oil sector.

\section{Donor Practices}

50. Tied aid contributes to weaken the PFM in Congo, reflecting the lack of predictability of budget support, and the fragmented information provided for budgeting and projects. This becomes a particularly acute problem when donors do not allow for competitive and transparent bidding on the investment projects they finance.

\section{Priority Areas for Reform}

51. Key priority measures agreed upon by World Bank and IMF staff with the authorities aim at improving Congo's PFM system. As indicated above, various assessments conducted so far with the full consultation of the authorities have been instrumental in putting together a sequenced and prioritized action plan that distinguishes between immediate measures to be implemented and additional for the medium-and-long term. This sequencing reflects the state of Congo's capacity. The immediate measures are summarized below:

Implement a new functional classification of the budget to improve transparency and track poverty-related expenditures. The Fund is providing technical assistance, but progress has been slow so far.

$>$ Comply with the organic budget law, particularly on the delineation of responsibilities between the ministry of finance and the ministry of planning at the commitment stage of investment spending.

$>$ Eliminate the recourse to exceptional spending procedures, consistent with the organic budget law. 
Increase funding for institutions that carry out ex-post control of expenditures; make provision for some reports to be made public: improve coordination between the commitment and payment functions of the Ministry of Finance to reduce arrears.

$>$ Implement a new public investment management system, with World Bank assistance, to better align investment spending to the priorities in the PRSP.

$>$ Establish a new procurement code in line with best international standards to ensure transparency and fair competition.

$>$ Strengthen customs administration and the fight against tax fraud and corruption on the revenue side.

Improve the monitoring of the expenditure chain, with technical assistance from the Fund.

52. A common theme of the measures above is to rehabilitate the budget as a key economic policy tool. This will strengthen the budget process, which will, in turn, give the domestic stakeholders and creditors altogether some measure of confidence in the government's ability and intention to address poverty issues and use oil proceeds appropriately. In support of policy consistency between government priorities, the Congolese authorities need to put in place a strategic planning framework linking the PRSP and/or the attainment of the MDGs with a view to: (i) use the PRSP process to enhance the link between budget and poverty reduction; (ii) strengthen the linkages between planning and budgeting; and (iii) introduce a multi-year policy framework, which outlines realistic medium-term objectives and means to attain them.

\section{In addition, measures to strengthen PFM are being combined with other core} elements of the public sector reform process, and with strengthening fiscal governance and transparency. In this context, based on the findings of a recent audit report of the procedures for the awarding of the Marine XI oil concession, a number of measures are being considered to strengthen management of oil resources.

In the short term, these measures include:

A clarification of the role that SNPC should play in the future. In particular, should SNPC on behalf of the government remain a holder of mining rights and a de facto promoter and negotiator of these rights or act simply basically in accordance with its mandate as a production and commercial operator;

$>$ Decisions to stop direct negotiations for new blocks and awarding contracts only after a competitive bidding; 
$>$ The adoption of a presidential decree establishing the regulations under which all new contracts are subject to an open international competitive bidding and the obligations of the authorities to open bids by qualified companies all new blocks under known rules; and

$>$ The setting up of a registry of qualified firms that could either operate or co-participate in petroleum exploration and production operations in Congo.

54. Looking ahead, there are also a number of structural measures that could be implemented in the upcoming months after further evaluation. These include:

Modification of the institutional framework to provide a clear separation of responsibilities and roles between the sector authorities and the national oil company SNPC. In this context, we would advise the authorities to implement the "Algerian Model," both in terms of institutional setup and process for awarding contracts. This model has also been implemented successfully in several Latin American countries (Peru, Colombia, and Brazil) for more than a decade;

$>$ Adoption of a new Code des Hydrocarbures and required regulations to implement it;

$>$ Reform of the Code of Penal Law; and

Adoption of any other measure aimed at improving and strengthening the general framework. In particular, a regulatory framework and implementation procedures to enhance current mechanisms related to control, filing, data management, and information gathering.

\section{Supporting the Reform Process}

55. The successful implementation of the PFM reforms outlined above hinges upon support provided by the Fund and other TA providers to build up the institutional capacity. The involvement of donors as their role is expected to expand in the context of the forthcoming PRSP. Coordination on realistic technical assistance and support for greater transparency and accountability are crucial to enhance the budget process.

\section{E. Conclusion}

\section{The main conclusions that can be drawn from this chapter are as follows:}

Despite some advances, Congo's PFM system remains weak. More efforts are needed to modernize it and help improve the quality of public spending to increase growth and make progress in reducing poverty. 
A credible PFM system is crucial to ensure transparent management of oil revenue, and better public investment management, especially in terms of costing, project monitoring, and control of the delivery and quality of services. This would in turn underpin the growth process.

The priority areas for reforms outlined in the paper would help set in motion the dynamics of a credible budget process in Congo. Alongside more basic reforms in accounting, control and reporting (including a functional classification system for government spending), the country needs a medium-term framework for setting government priorities and expenditure allocations.

> Further progress in strengthening PFM is highly dependant on political economy factors, which need to be tackled over time as part of strengthening efforts toward governances and transparency.

$>$ Donors have an important responsibility to support and facilitate the reform process. The Fund, the World Bank, and other donors should continue their support in favor of reforming the PFM system in Congo. 


\section{References}

Allen, Richard and Dimitar Radev, 2006, "Managing and Controlling Extrabudgetary Funds" (forthcoming; Washington: International Monetary Fund).

Barnett, Steven, and Rolando Ossowski, 2003, "Operational Aspects of Fiscal Policy in OilProducing Countries," in Fiscal Policy Formulation and Implementation in OilProducing Countries, ed. by J. Davis, R. Ossowski, and A. Fedelino (Washington: International Monetary Fund).

Bartsch, Ulrich, Menachem Katz, Harinder Malothra, and Milan Cuc, 2004, "Lifting the Oil Curse, Improving Petroleum Revenue Management in Sub-Saharan Africa" (Washington: International Monetary Fund).

Diamond, Jack, 2006, "Budget System Reform in Emerging Economies, The Challenges and the Reform Agenda,” IMF Occasional Paper No. 245 (Washington: International Monetary Fund).

Economic Commission for Africa, 2005, "Assessing Public Financial Management and Accountability in the Context of Budget Transparency in Africa."

Eifert, Benn, Alan Gelb, and Nils Borje Tallroth, 2003, "The Political Economy of Fiscal Policy and Economic Management in Oil-Exporting Countries," in Fiscal Policy Formulation and Implementation in Oil Producing Countries, ed. by J. Davis, R. Ossowski, and A. Fedelino (Washington: International Monetary Fund).

International Monetary Fund, 2004, "Public Investment and Fiscal Policy," (www.imf.org). , 2007, "République du Congo: Propositions pour l'amélioration de la nomenclature budgétaire et l'introduction d'une classification fonctionnelle." Technical Assistance report by Dominique Bouley, Jean-Pierre Nguenang et JeanGustave Sanon.

Kaufmann, Daniel, Aart Kraay, and Massimo Mastruzzi, 2005, "Governance Matters IV: Governance Indicators for 1996-2004,” World Bank Policy Research Working Paper 3630 (Washington: World Bank).

Oxford Policy Management (OPM), 2000, Medium-Term Expenditure FrameworksPanacea or Dangerous Distraction?, OPM Review.

Pollitt, Christopher, and Geert. Bouckaert, 2004, "Public Management Reform: A Comparative Analysis." 
Public Expenditure and Financial Accountability (PEFA) Secretariat, World Bank, 2000, “ Performance Measure Framework.

Potter, Barry, and Jack Diamond, 1999, Guidelines for Public Expenditure Management (Washington: International Monetary Fund).

Schick, Allen, 1998, A Contemporary Approach to Public Expenditure Management (Washington: World Bank).

Spackman, Michael, 2002, "Multi-Year Perspective in Budgeting and Public Investment Planning," Draft background paper for discussion at Session III.1 of the OECD Global Forum on Sustainable Development (Paris: OECD).

World Bank, 2006, “ République du Congo: Note Analytique sur les Marchés Publics.” 


\section{Governance ANd TransParenCy in THE RePUblic OF CONGo ${ }^{10}$}

\section{A. Introduction}

57. As part of its renewed engagement in low-income countries, the international community has both extended debt relief and announced plans to increase development aid. In June 2005, the international community agreed to cancel 100 percent of the outstanding debts of eligible Heavily Indebted Poor Countries (HIPC) to the International Monetary Fund (IMF), the International Development Agency (IDA), and the African Development Fund (ADF) and to double development aid by 2010. Of the annual $\$ 50$ billion expected increase in aid, about half is to be earmarked for Africa. The 2005 G8 declaration adds to earlier agreements reached in the context of the MDGs. ${ }^{11}$

58. Congo's eligibility for such debt relief and development aid-as well as its ability to effectively benefit from such aid-hinges on its ability to improve its governance and transparency record. Debt relief and aid programs typically benefit low-income countries with a strong commitment to growth and poverty reduction; democratic, accountable, and transparent governments; and sound public financial management policies. However, according to the World Bank, Congo continues to lag behind the average of the countries in its region, the Communauté Économique et Monétaire de l'Afrique Centrale (CEMAC), on such perception indicators as government effectiveness, control of corruption, and rule of law.

59. A review of Congo's recent record on governance and institutional transparency indicates the need for significant efforts to address corruption and fraud in order to attract foreign (nonoil) direct investment, encourage entrepreneurship, and boost growth. The adoption of a roadmap to address corruption and enhance governance, especially in public financial management, is key to Congo reaching HIPC debt relief. The triggers, included in the HIPC Decision Point Document, ${ }^{12}$ summarize the reforms Congo has committed to undertake in order to reach the HIPC completion point and thus become eligible for debt relief of about $\$ 1.7$ billion in 2004 in net present value (NPV) terms. In addition, under the Multilateral Debt Relief Initiative (MDRI), at the HIPC completion point, Congo will benefit from the cancellation of Congo's outstanding debt as of end-2004 to the IMF, IDA, and ADF.

\footnotetext{
${ }^{10}$ Prepared by Maria Oliva, with inputs from Francis Bokilo.

${ }^{11}$ European Union members will give 0.56 cents of every dollar of their revenue to poor countries by 2010, and increase it to 0.7 cents by 2015 . The United States have also announced plans to double overseas development aid.

${ }^{12}$ The document is available at http://www.imf.org/external/country/COG/index.htm.
} 
60. The paper is organized as follows. The first section summarizes the evidence about the impact of good governance on growth and competitiveness, and reviews factors promoting good governance and the costs of having weak governance. The second section compares the World Bank's governance rankings for Congo with those for CEMAC and other African countries. The third section provides background on Congo's weak performance on governance and transparency indexes and measures considered to fight corruption. Conclusions follow.

\section{B. Governance, Growth, and Competitiveness}

61. High-quality institutions support economic development. The World Bank's report, A Decade of Measuring the Quality of Governance (2006), calls it "the 300 percent development dividend." That is, a country's long-term per capita income will triple after governance ${ }^{13}$ improves by one standard deviation. ${ }^{14,15}$ Empirical evidence also suggests that governance improvements prompt per capita income gains and not vice versa. And, while improvements in governance can take time, governance institutions can deteriorate in just a few years. The report further notes that at least one governance indicator changed significantly for about one third of the countries and territories (out of a sample of 213) in 1996-2005.

62. Poor governance and corruption hurt long-term economic growth. As shown in Easterly, Ritzen, and Woolcock (2006), differences in the quality of institutions can account for much of the growth differential between countries. For a sample of 67 developed and developing countries, Mauro (1995) estimates that a one-standard-deviation improvement in the control of corruption translates into a 0.8 percentage increase in the annual growth rate of per capita GDP. A one-standard-deviation improvement in the bureaucracy efficiency index yields a 1.3 percentage point increase in the annual per capita GDP growth rate. ${ }^{16}$ Using firm-level data for Uganda in 1995-97, Fisman and Svensson (2000) find that a one-

\footnotetext{
${ }^{13}$ See Appendix 1 for a detailed definition of governance.

${ }^{14}$ According to the World Bank (2006) report, A Decade of Measuring the Quality of Governance, a one standard deviation improvement is only a fraction of the difference between the worst and best performers and is thus within reach. On rule of law, for example, there is a gap of one standard deviation between Somalia and Nigeria and between Nigeria and El Salvador. On control of corruption, there is a gap of one standard deviation between Equatorial Guinea and Tanzania and between Tanzania and Lithuania.

${ }^{15}$ Tanzi and Davoodi (2000) similarly find a statistically significant negative correlation of -0.8 between lowincome per capita GDP and perceptions of corruption. Acemoglu, Johnson, and Robinson (2001) show that a country's quality of institutions (e.g., secure property rights) directly affects its level of development.

${ }^{16}$ Tanzi and Davoodi (2000) also find a statistically significant negative correlation of -0.32 between a low GDP growth rate and perceptions of corruption.
} 
percentage-point increase in the bribery rate is associated with a three-percentage-point drop in firm growth.

\section{There is a positive correlation between competitiveness and the control of} corruption and the rule of law. Control of corruption and enforcement of the rule of law in 2005 are positively correlated with competitiveness ${ }^{17}$ in 2006 (Figure IV.1). Kaufmann (2006) similarly finds that, on average, a one standard deviation increase in the control of corruption is related to a 30-position gain in a country's GCI ranking. Controlling for the country's income, the gain falls to $15-20$ positions.

\section{Causes and Consequences of Weak Governance and Corruption}

\section{A number of factors associated with monopoly, discretionary power, oil} resources, and asymmetries in information provide opportunities to shelter weak institutions and corrupt behavior (see Box IV.1 for a detailed discussion). Weak governance and corruption practices are often encouraged by the absence of competition, policy distortions, size of the government, political systems, and public servants' salaries among others. In this context, world economic integration, openness, and the simplification of regulatory frameworks can be seen as discipline mechanism devices against corruption and poor governance. The forces of globalization and world economic integration increase the pressure to fight corruption and enhance governance. ${ }^{18}$ Measures to be considered include: liberalization of domestic trade policies (see Gulde-Wolf et al. (2006), and Oliva (2007) for concrete trade reform measures), domestic price liberalization, privatization, and the adoption of comprehensive competition laws.

\footnotetext{
${ }^{17}$ The charts include a sample of 115 countries and use the World Economic Forum (WEF) Global Competitiveness Index (GCI) as a proxy for competitiveness and for nations' standard of living.

${ }^{18} \mathrm{Ng}$ and Yeats (1998) find that countries with better governance and less restrictive trade policies are associated with significantly higher per capita GDP levels, higher export and import growth rates, and are more successful in integrating into the global economy. Their empirical results show that domestic trade and governance regulations help to explain more than 60 percent of the variance in some measures of economic performance. They conclude that poorer open countries tend to integrate into the global economy faster than closed economies.
} 
Figure IV.1. Competitiveness and the Control of Corruption and the Rule of Law
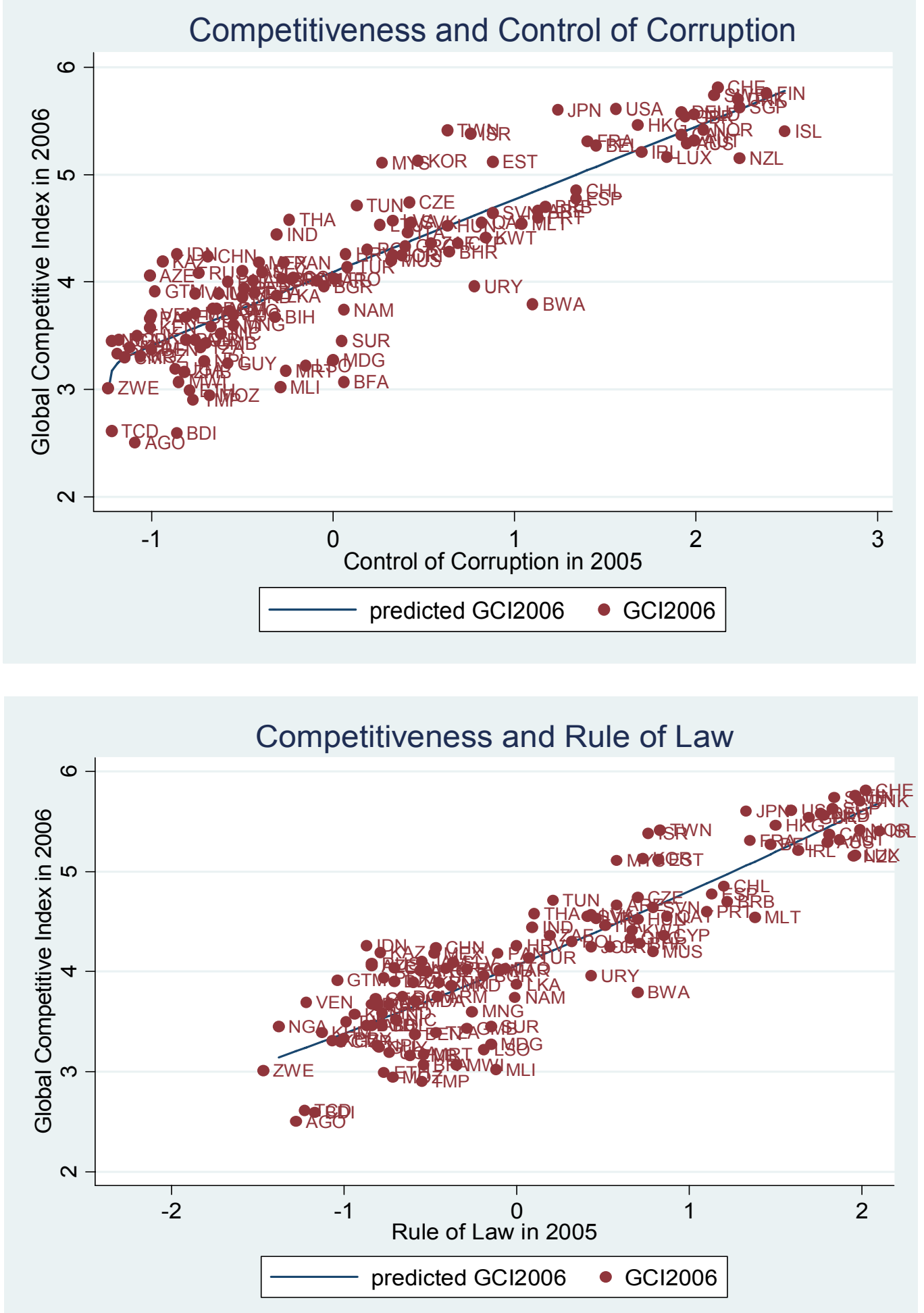

Source: Fund staff estimates, based on the Global Competitiveness Index (GCl). 


\section{The consequences and costs of poor governance on growth and competitiveness} can be grouped in terms of their impact on revenue and spending. Corruption and poor governance raise transaction costs and uncertainty in the economy, and tend to lead to inefficient economic outcomes (Box IV.2). As such:

From the revenue side, poor governance is associated with low tax revenue collection due to, among others, tax evasion and rampant concession of tax exemptions; regressive tax schemes, and income inequality. It encourages firms to operate outside the formal sector.

$>$ From the spending side, inefficiencies arise from the suboptimal allocation of private and public resources, ${ }^{19}$ the misallocation of talents to rent-seeking activities, the waste of resources in unproductive activities, ${ }^{20}$ the misuse of aid inflows through the diversion of funds and the loss in terms of effectiveness, the exposition of countries to crises by distorting the type of capital inflows received by the country, and others.

\section{Box IV.1 Literature on Causes of Weak Governance and Corruption}

Factors associated with weak governance include:

$>$ Lack of Competition. Competition reduces incentives for red tape and corruption by reducing the profitability of economic activities (Ades and Di Tella 1999, Clarke and Xu 2002). As such, trade restrictions, price controls, and multiplicity of exchange rate practices are prime examples of government-induced sources of rents.

$>$ Size of the government and pervasive and cumbersome regulations. Government involvement in private markets is typically perceived as a source of corruption (La Palombara 1994, La Porta et al. 1999, Rose-Ackerman 1999, Lynn 2001, Kaufmann 1997).

$>$ Low civil servants' pay relative to wages in the private sector. Evidence shows that the higher the ratio of government wages to manufacturing wages, the lower is the level of corruption in a country (Van Rijckeghem and Weder 2001, Rauch and Evans 2000, Besley and McLaren 1993, and Mookherjee and Png 1995).

$>$ Natural resources. Natural resource abundance has an adverse institutional impact as the generated rents can be easily appropriated; a feature that fuels insatiable rent seeking behavior (i.e., the so-called voracity effect). By directly controlling access to natural resources, officials are faced with opportunities to exploit the associated rents, and this behavior may spill over to other segments of the society (Ades and Di Tella 1999, Leite and Weidemann 1999, Sala-i-Martin and Subramanian 2003, Michael Ross 2001).

\footnotetext{
${ }^{19}$ See also Mauro (1995), Shleifer and Vishny (1993), Rose-Ackerman (1996).

${ }^{20}$ See, for example, Bhagwati (1982), Brooks and Heijdra (1988), Krueger (1974), Lien (1990), and Tullock (1967).
} 


\section{Box IV.2: Consequences of Weak Governance and Corruption}

From the revenue side, poor governance is linked to poor tax revenue collection and regressive tax schemes. Corruption is associated with lower government revenue that is needed to finance productive spending. That is:

- Gap between tax revenue collected by administrators and received in the treasury. Countries with higher levels of corruption tend to have lower tax revenues collection (Tanzi and Davoodi 2000, Ghura 1998).

$>$ Less progressive tax systems. Corruption and poor governance are a regressive tax on the poor (Hindriks, Keen, and Muthoo 1999) as they: (i) distort the allocation of public resources and hinder access to basic services (e.g., health and education); (ii) impose higher costs on small and medium size enterprises in their access to markets relative to those faced by large firms; and (iii) force the poor to spend more on bribes (in terms of their income) relative to the well-off.

From a spending side, corruption and institutional inefficiencies hamper economic growth by taxing productivity and distorting market activity. Empirical evidence points at the negative impact corruption and institutional inefficiencies have on:

Lower private sector investment. Corruption and poor governance hamper investment by altering investments' rate of return, increasing uncertainty and causing the misallocation of investments across sectors (Mauro 1995, Sevnsson 1998, Campos, Lien and Pradhan 1999, and Wei 1997)

$>$ Less small and medium size enterprises (SMEs). For SMEs, corruption often entails higher operating costs related to payments that do not enhance the firm's productivity or profitability levels, but are necessary to remain in the market (the Business Environment and Enterprise Performance Survey (BEEPS), Tanzi and Davoodi 2000).

$>$ Less and more volatile capital flows. Wei and $\mathrm{Wu}$ (2001) argue that corruption biases the composition of capital inflows away from foreign direct investment and in favor of portfolio investments (say, international bank loans). In addition, political instability and poor governance propel capital flight (Lee and Rishi (2005)).

$>$ Less foreign direct investment (FDI) and "risk averse" modes of involvement. Corruption works as a tax on foreign investors as it brings uncertainty into the markets (Wei 2000, Smarzynska and Wei 2002).

$>$ More public sector investment but higher costs and lower quality. The OECD African Economic Outlook 2005/2006 ${ }^{1}$ cites examples in which corruption increases the cost of public investment, especially in the area of public procurement, and lowers the quality of public services (OECD African Economic Outlook 2005/2006 ${ }^{1}$, Tanzi and Davoodi 1997, Collier and Hoeffler 2005, Mauro 1998, Gupta, Davoodi and Alonso-Terme 1998, Gupta, de Mello, and Shartan 2000).

Rent seeking and misallocation of talent. Rent-seeking and corruption reduces income by encouraging able individuals to follow law courses rather than more productive engineering studies (Murphy, Shleifer, and Vishny 1991). 


\section{Governance in CEMAC Countries}

66. Improving governance and curbing corruption remains an important challenge for CEMAC countries. According to the World Bank's 2006 governance indicators, CEMAC countries rank well behind Botswana, Ghana, Mozambique, Senegal, and other African countries (Appendix IV.1). The World Bank indicators control for perceptions of both local citizens and CEOs of firms operating in the country. ${ }^{21}$ As such, these measures provide an indication of residents' assessment of government performance and policies, the extent of discretionary practices, compliance with the rule of law, and other factors (see Appendix IV.2 for the rankings and Kaufmann, D., A. Kraay, and M. Mastruzzi 2006 for a detailed description of the methodology used).

67. The average governance performance of CEMAC countries has deteriorated in recent years (Figure IV.2). Perceptions of the government's capacity to formulate and implement its policies (i.e., the government efficiency index) and its ability to legitimately exercise authority (i.e., the rule of law) have significantly deteriorated. On the control of corruption index, CEMAC countries' performance has been deteriorating slightly since 2002. Relative to 2004 rankings, 2005 perceptions on the control of corruption and government effectiveness have also worsened, while perceptions on voice and accountability have remained unchanged. Only the regulatory environment and political stability indexes have improved.

68. CEMAC countries, on average, scored worse on governance and transparency than did the West African and Monetary Union (WAEMU), the East African Community (EAC), Southern African Customs Union (SACU), and the rest of SubSaharan economies in 1996-2005 (Table IV.1). CEMAC lagged well behind these other arrangements on five of the six governance dimensions (the exception was political stability, against which only the EAC performed worse than CEMAC).

\footnotetext{
${ }^{21}$ All governance indicators are based on survey results. In this respect, these indicators are all subjective in nature, as they reflect a person's perception of the current governance conditions in a specific country, rather than objective output measures of the impact of governance. They should therefore be treated with caution. The advantage of the Kaufmann, Kray, and Mastruzzi (2006) indicators over other indicators is that they are based on several hundred individual variables measuring perceptions of governance, drawn from 37 separate data sources constructed by 31 different organizations. In this context, these indicators are likely to be the least biased and the ones that provide the best cross-country comparability, albeit still from the subjective perspective of local citizens and CEOs of companies operating in the country.
} 
Figure IV.2. Governance Indicators for Congo, 1996-2005

Dimension 1: Process by Which the Government is Selected and Replaced

Indicator 1: Voice and Accountability

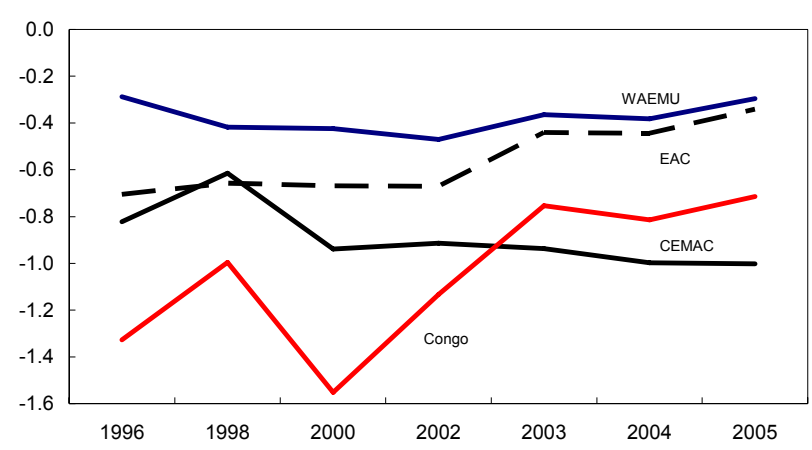

Indicator 2: Political Stability

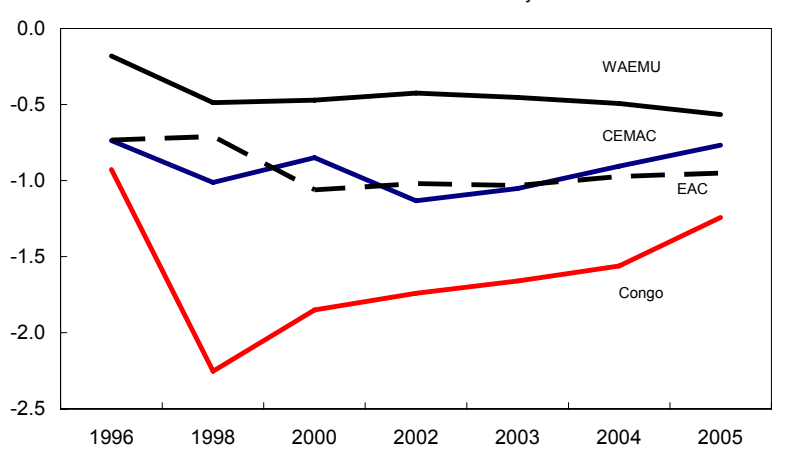

Dimension 2: The Capacity of the Government to Formulate and Implement Policies
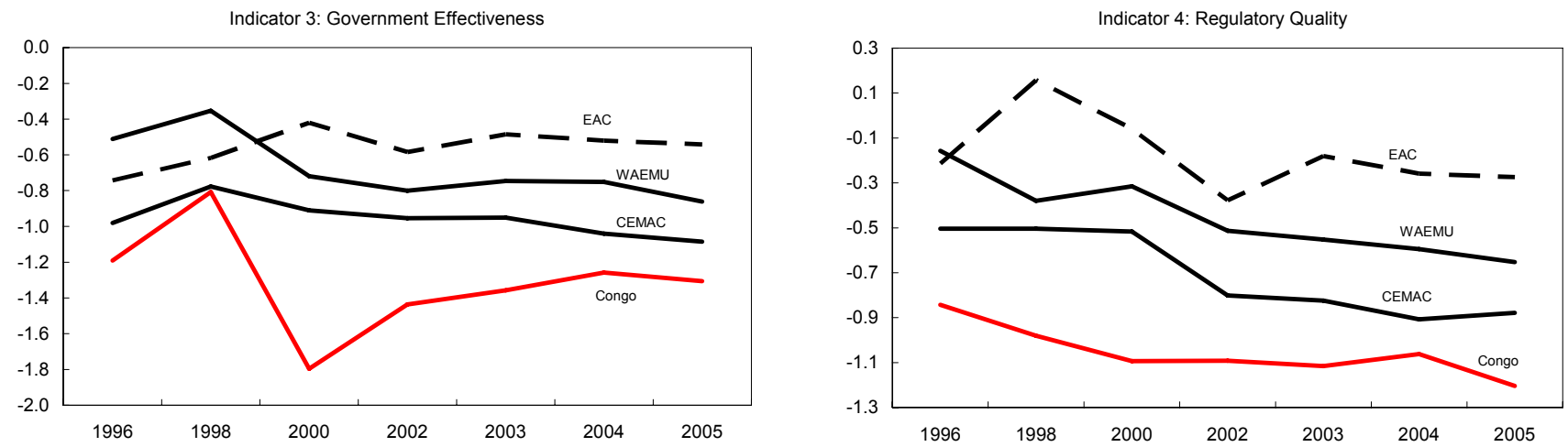

Dimension 3: Respect of Citizens and State for Institutions that Govern Interactions Among Them
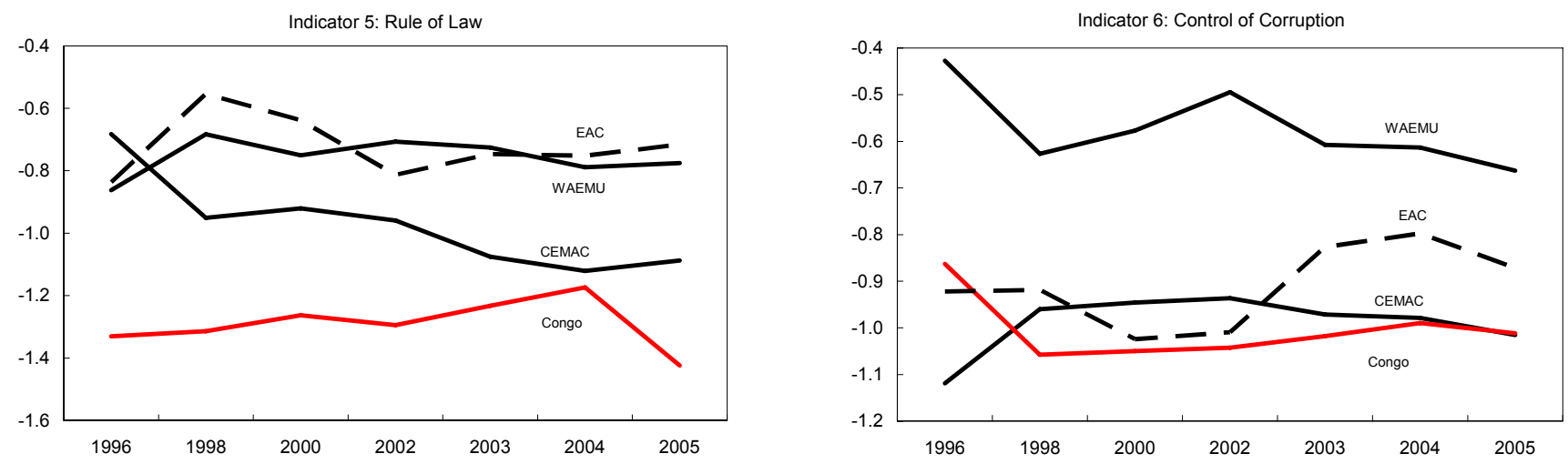

Sources: World Bank (2006). 


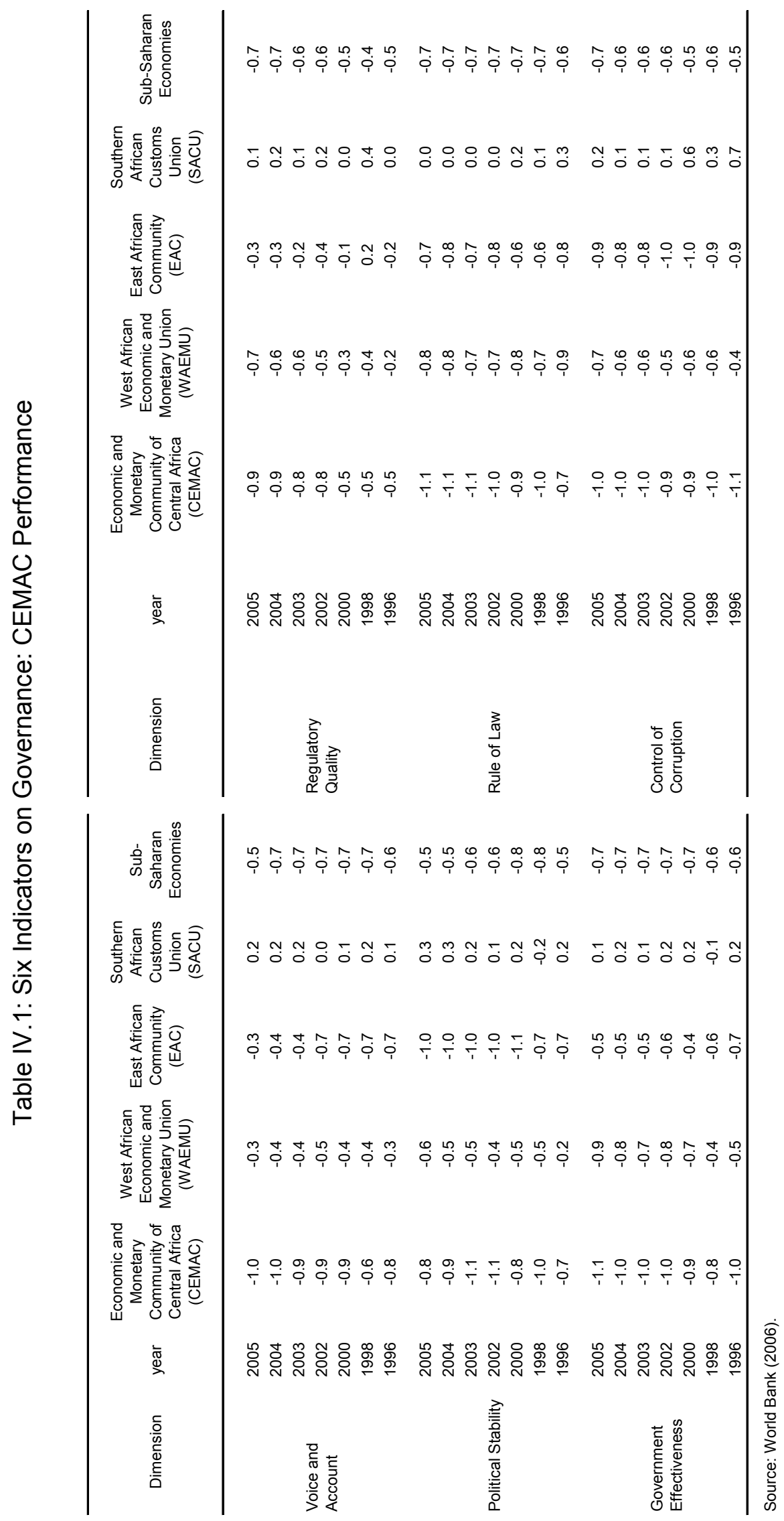




\section{E. Congo's Record on Governance}

69. Congo's overall governance record is weak. Except for the voice and accountability index, Congo scores below the CEMAC country average on the six indexes of governance published by the World Bank (Table IV.2). Important improvements have been achieved in the area of political stability, though it still ranks in the last quartile. However, little improvement has been achieved in the control of corruption.

Table IV.2. Republic of Congo: Summary of Governance Indicators, 1996-2005

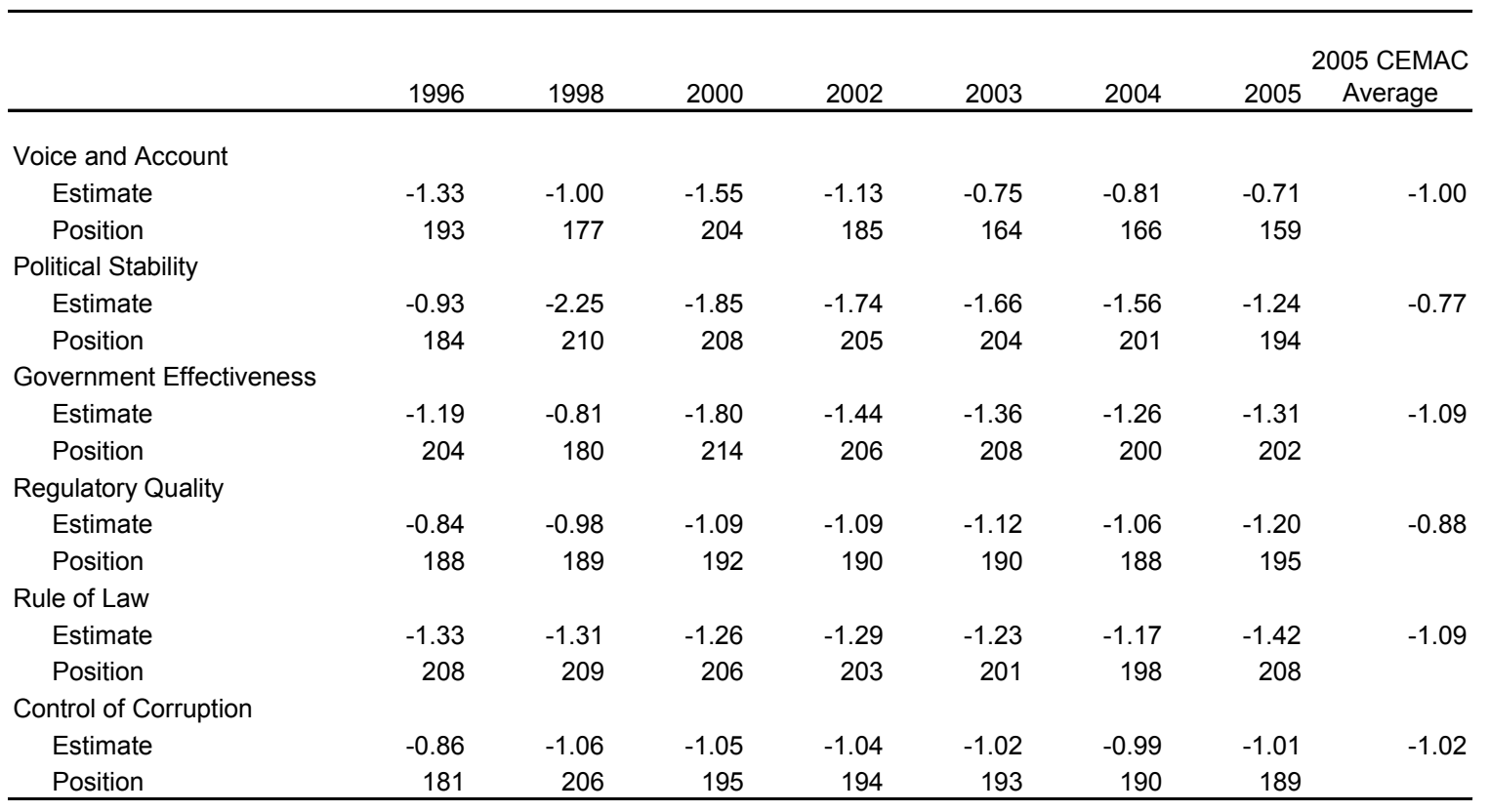

Source: World Bank (2006).

70. Perceptions of the government's capacity to formulate and implement policies, observe the rule of law, and control corruption deteriorated from 2004 to 2005 . Congo's ranking fell on a number of indicators (by 10 for rule of law, 7 for regulatory quality, and 2 for government effectiveness), making it one of the worst governance performers in a sample of 213 countries and territories. The publication of two court cases and press reports detailing Congo's governance and transparency problems in the oil sector ahead of the HIPC Decision Point document may have also significantly affected the governance perceptions in 2005, as measured by the World Bank indicators.

\section{Governance indicators for Congo generally do not appear to be highly}

correlated (Table IV.3), though control of corruption appears closely related both to the regulatory environment and political stability. Improvements in the political stability index, however, cancelled out with the worsening in the regulatory quality index. In contrast with other sub-Saharan economies, in Congo (but also in other CEMAC economies), there seems 
to be no relationship between political stability and voice and external accountability, likewise between the rule of law and accountability. In the case of CEMAC countries, government effectiveness tends to be highly correlated with the voice and accountability index, while in Congo the correlation is moderate. Rule of law and regulatory quality move hand-in-hand in CEMAC countries, but not in Congo.

Table IV.3. The Correlation between Alternative Indicators of Governance

\begin{tabular}{|c|c|c|c|c|c|c|}
\hline & $\begin{array}{c}\text { Voice and } \\
\text { Account }\end{array}$ & $\begin{array}{l}\text { Political } \\
\text { Stability }\end{array}$ & $\begin{array}{c}\text { Government } \\
\text { Effectiveness }\end{array}$ & $\begin{array}{c}\text { Regulatory } \\
\text { Quality }\end{array}$ & $\begin{array}{c}\text { Rule of } \\
\text { Law }\end{array}$ & $\begin{array}{l}\text { Control of } \\
\text { Corruption } \\
\end{array}$ \\
\hline \multicolumn{7}{|l|}{ Congo } \\
\hline Voice and Account & 1.0 & & & & & \\
\hline Political Stability & 0.0 & 1.0 & & & & \\
\hline Government Effectiveness & 0.4 & -0.1 & 1.0 & & & \\
\hline Regulatory Quality & -0.5 & 0.2 & 0.4 & 1.0 & & \\
\hline Rule of Law & 0.0 & -0.3 & -0.2 & 0.1 & 1.0 & \\
\hline Control of Corruption & -0.2 & 0.8 & 0.2 & 0.7 & -0.1 & 1.0 \\
\hline \multicolumn{7}{|l|}{ CEMAC } \\
\hline Voice and Account & 1.0 & & & & & \\
\hline Political Stability & -0.2 & 1.0 & & & & \\
\hline Government Effectiveness & 0.9 & -0.5 & 1.0 & & & \\
\hline Regulatory Quality & 0.7 & 0.2 & 0.7 & 1.0 & & \\
\hline Rule of Law & 0.5 & 0.3 & 0.3 & 0.8 & 1.0 & \\
\hline Control of Corruption & -0.1 & -0.7 & 0.4 & -0.2 & -0.6 & 1.0 \\
\hline \multicolumn{7}{|l|}{ Sub-Saharan Africa } \\
\hline Voice and Account & 1.0 & & & & & \\
\hline Political Stability & 0.7 & 1.0 & & & & \\
\hline Government Effectiveness & 0.8 & 0.7 & 1.0 & & & \\
\hline Regulatory Quality & 0.7 & 0.6 & 0.9 & 1.0 & & \\
\hline Rule of Law & 0.8 & 0.8 & 0.9 & 0.8 & 1.0 & \\
\hline Control of Corruption & 0.7 & 0.7 & 0.9 & 0.8 & 0.9 & 1.0 \\
\hline
\end{tabular}

Source: World Bank (2006) and Fund staff estimates.

\section{F. Strengthening Governance and Fighting Fraud}

\section{As shown in the previous section, governance and the fight against corruption} are a long standing issue in Congo. According to the 2005 Transparency International's corruption perception index (CPI), Congo ranks 130 out of 158 countries, compared with 113 out of 135 countries in 2003. In early 2003 the Congolese government, in partnership with the United Nations Development Program (UNDP) and with the support of an international expert from Transparency International, conducted a survey on fraud and corruption within the public sector. The overall survey objective was to assess the level of fraud and corruption as well as its causes and consequences in the development of the country. The survey confirmed the perception of widespread corruption in the public sector (Box IV.3). 


\section{Box IV.3: 2003 Corruption Survey: Five Main Findings}

The main findings of the corruption perception survey ${ }^{22}$ are as follows:

1) There is widespread corruption, misappropriation of public funds, and fraud in the public sector; monetary corruption is the principal form of corruption.

2) Corruption mostly affects public sector agents; the main causes of corruption are lack of control, low salaries, poverty, inefficiency in the legal system, and patronage (particularly in election periods).

3) The most-affected sectors or institutions are the customs and tax offices, the police, the judiciary, education, the treasury, state procurement systems, and the health sector.

4) The least-effected sectors or institutions are churches, the senate, and the national assembly.

5) The legal and regulatory system is inadequate in fighting fraud and corruption.

The findings of the survey were analyzed and discussed during the "National days to fight fraud and corruption" held at Brazzaville from 11 to 13 December 2003 and involving civil society and the private sector.

\section{The Congolese authorities responded to the 2003 survey with a number of} measures that have, to date, lead to elusive results (Box IV.4). The World Bank and Transparency International indicators on corruption show advances have been quite limited. Allegations of widespread misuse of public funds, and corruption practices have found support in recent international court cases ${ }^{23}$ that detail irregular oil marketing practices by the Congolese government. Initiated by the so-called judgment creditors, ${ }^{24}$ these Court rulings contributed to corroborate accusations of mismanagement. As a result, in approving Congo's access in March 2006 to the HIPC Decision Point, the Fund and the World Bank Executive Boards focused on a number of measures to tackle weak governance concerns in oil management, and resource management in general as triggers for reaching debt relief.

\footnotetext{
${ }^{22}$ UNDP and the Ministry in Charge of State Control (2003)

${ }^{23}$ In London and New York.

${ }^{24}$ Judgment creditors are creditors who have obtained one or more court orders validating their claims, and who are therefore entitled to engage in asset seizure. Typically, they are investment funds that have bought debt in the secondary market at a discount.
} 


\section{Box IV.4: Government Responses to the 2003 Corruption Survey}

In response to the 2003 survey, the Congolese government:

adopted a national plan to fight corruption, the misappropriation of public funds, and fraud (2004);

created a National Commission to fight both corruption and the misappropriation of public funds (July 2004) and appointed commission members by a presidential decree (September 2005);

$>$ established the Court of Accounts to monitor the use of public money (early 2005);

ratified the United Nations and the African Union Convention on the prevention and fight against fraud (2005); and

$>$ adopted a presidential decree to prevent conflicts of interest between SNPC's board of directors and those with management responsibilities within SNPC and its subsidiaries (January 2006).

\section{Improving governance has been and remains a key pillar of Congo's program} with the IMF. The Fund-supported policy of transparency and good governance in Congo is aimed at maximizing government oil revenues and improving financial management of natural resources, and relied on three main pillars: (i) institutional and legal; (ii) the government budget; and (iii) the national oil companies. In addition, transparency in the form of internet publication of audited data is seen as a key tool in the strategy to fight fraud and to encourage good governance (Box IV.5).

\section{To reach debt relief under the HIPC Initiative, the Congolese authorities need to} redouble their efforts to address a number of governance challenges. The negative impact of poor governance on the fight against poverty has prompted international institutions (notably the IMF and the World Bank) to stress conditionality on governance and resource management. ${ }^{25}$

\section{A number of weaknesses have been identified at the operational and institutional} level in Congo. Improvements in governance encompass improving Congolese check and balance institutions, the awarding of natural resources' concessions, and competitive and transparent procurement practices, among others:

\footnotetext{
${ }^{25}$ HIPC Completion Point triggers refer to the measures authorities committed to undertake to reach Completion Point, and therefore secure irrevocable HIPC debt relief.
} 


\section{Box IV.5. Congo's Progress on Governance Since 2003}

The authorities' key governance reforms since 2003 are summarized in the bullets below:

Establishment in 2003 of the specialized oil monitoring unit within the Ministry of Finance to help the government better project oil revenues and negotiate production sharing agreements with private oil companies.

> Adoption in 2003 of a convention clarifying the legal and financial relationships between the state, the national oil company (SNPC), and the national oil refinery (CORAF).

Adoption by the government in 2004 of a dividend policy allocating 20 to 30 percent of SNPC's net profit to the treasury.

Membership since 2004 in the Extractive Industries Transparency Initiative (EITI), a transparency initiative in extractive industries (see http://www.eitransparency.org/).

Publication on the internet of key oil data, oil-related audit reports, and data on oil and gas transactions (see http://www.mefb-cg.org/).

Centralization of all government oil revenues collected by the treasury (since 2003).

Audits of oil costs to maximize the government's share of oil profits (since 2004).

$>$ Phasing out of costly and nontransparent oil-backed loans (since 2002).

$>$ Phasing out of extra budgetary financing by national oil companies (since 2003).

$>$ Quarterly certification of government oil revenues by a reputable auditor (since 2003).

$>$ Audits of SNPC accounts (since 1999) and creation of a plan to implement audit recommendations, particularly items pertaining to the internal control, accounting, and marketing of oil on behalf of the state.

$>$ Audits of the CORAF annual accounts (since 2002).

D Completion of a certification report in 2006 that public officials are not personally benefiting from government oil sales by the SNPC or its subsidiaries.

Operational weaknesses in Congo's control and audit institutions. In fact, the Parliament has very little control over the executive branch on public finance matters. Indeed, budgets are voted with long budget delays, because the government does not communicate to parliament the draft budget on time. Late reporting typically weakens budget oversight. The relatively new National Audit Office (Cour des Comptes) is understaffed both in terms of human capacity and material means; its magistrates, who are mainly lawyers, have little background in government finance. Strengthening the 
capacities of parliament and other institutions overseeing the government is thus a priority.

$>$ Poor management standards, limited accountability, and lack of financial integrity. Oil sector audits have evidenced there is still ample scope for improvements in the internal control and accounting of SNPC and CORAF and the cost structure of refined petroleum products.

Deficiencies in awarding procedures of contracts. The audit on the Marine XI concession revealed gaps in the awarding of oil concessions (http://www.mefbcg.org/petrole/dp) in the legal and regulatory systems, which fail to prevent potential conflicts of interest and enable Congo to maximize its gains from oil concessions. Forward-looking correcting measures proposed in the audit include: (i) the clarification of SNPC's role in the awarding process; (ii) a review of the legal and regulatory framework of the sector; (iii) the establishment of an auction procedure suitable for the awarding of oil concessions; and (iv) the reform of Congo's legal code to address conflicts of interest.

The procurement system needs overhauling. According to a 2006 procurement review by the World Bank, most procurement operations are nontransparent and noncompetitive. The procurement system relies on two different institutions (both of which are headed by the President's Office): the « Direction Centrale des Marchés et Contrats de l'Etat (DCMCE) », which handles contracts of less than CFAF 500 millions, and the «Délégation des Grands Travaux (DGT) », which processes contracts of more than CFAF 500 million.

77. Transparency in the management of natural resources will bring about the necessary changes. The Congolese authorities have committed to implementing two transparency-related international initiatives:

Dxtracting Industries Transparency Initiative (EITI). Congo adhered to this Initiative in June 2004. Since then, there has been some progress but much more in needed before the first EITI report is published. To date, the authorities have approved two decrees creating the national consultative and the executive EITI committees were signed in October 2006. Members of the two EITI committees, however, remain to be named.

$>$ Congo has yet to be readmitted to the Kimberly process on diamond certification. ${ }^{26}$ Before being excluded from the Kimberly process in July 2004, Congo was exporting 4 to 5 million carats a year but officially producing only 50,000 carats (most of the excess

\footnotetext{
${ }^{26}$ See http://www.kimberleyprocess.com:8080/
} 
was believed to come from the Democratic Republic of Congo). To be readmitted to the Kimberly process, Congo needs to: (i) explain the export-production gap; (ii) report on its mining legislation; and (iii) submit an assessment of its diamond production potential. To comply with these demands, the authorities changed the mining law and funded two official studies. Experts from a French geological service completed a survey and submitted it in May 2006 to the Kimberly Process Secretariat.

\section{G. Conclusions}

78. The Congolese authorities need to intensify their efforts to improve governance and transparency in order to achieve sustainable growth, and reach debt relief under the Enhance HIPC Initiative and the MDGs. The theoretical literature on governance is clear: good governance and transparency promote growth. The World Bank, in distilling this literature, has identified a "development dividend" that shows that the implementation of good governance and transparency can triple per capita income. While the case for good governance has been clearly incorporated into a series of IMF-supported programs, governance and transparency in Congo continue to lag behind the level of most developing countries in Africa and other parts of the world. The March 2006 HIPC Decision Point document incorporates a number of triggers for debt relief that have been identified as key measures for improving governance in Congo in the next few years. Implementation of these measures will be essential for economic development and securing the debt relief. 


\section{References}

Acemoglu, A., S. Johnson, and J. Robinson, 2001: The Colonial Origins of Comparative

Development: An Empirical Investigation, American Economic Review, vol. 5, 1369-1401.

Ades, A., and R. Di Tella, 1999: Rents, Competition and Corruption, American Economic Review 89/4, 982-994.

Besley, T. and J. McLaren, 1993: Taxes and Bribery: The Role of Wage Incentives, Economic Journal, Royal Economic Society 103/416, 119-41.

Brunetti, A.; Kisunko, G.; Weder, B., 1997: Credibility of Rules and Economic Growth, World Bank, Policy Research Working Paper 1760.

Brunetti, A. and B. Weder 1998: Investment and Institutional Uncertainty: A Comparative

Study of Different Uncertainty Measures", Weltwirtschaftliches Archiv, CXXXIV, 513-33.

Campos E., D. Lien, and S. Pradhan, 1999: The Impact of Corruption on Investment, Predictability Matters, World Development 27, 1059-1067.

Clarke, G. and L. Xu, 2002: Ownership, Competition, and Corruption: Bribe Takers versus Bribe Payers, World Bank Policy Research Working Paper No. 2783, (Washington D.C.: World Bank).

Collier, P. and A. Hoeffler, 2004: Greed and grievance in civil war, Oxford Economic Papers, 56/4, 563-595.

Easterly, W., J. Ritzen, and M. Woolcock, 2006: Social Cohesion, Institutions, and Growth, Economics and Politics, Blackwell Publishing, vol. 18(2), pages 103-120, 07.

Fisman, J. and R. Svensson, 2000: Are Corruption and Taxation Really Harmful to Growth? Firm-Level Evidence, World Bank Policy Research Working Paper No. 2485. (Washington D.C.: World Bank).

Ghura, D., 1998: Tax Revenue in Sub-Saharan Africa: Effects of Economic Policies and Corruption, IMF Working Paper No. 98/135, (Washington D.C. International Monetary Fund).

Gupta, S., H. Davoodi and R. Alonso-Terme, 1998: Does Corruption Affect Income Inequality and Poverty?, IMF working paper, (Washington D.C. International Monetary Fund). 
Gupta, s., L. de Mello, and R. Sharan, 2000: Corruption and Military Spending, IMF Working Paper No. 00/23 (Washington D.C. International Monetary Fund).

Hindriks, J., M. Keen and A. Muthoo, 1999: Corruption, extortion and evasion, Journal of Public Economics, Elsevier, vol. 74/3, 395-430.

Kaufmann, D., 1997: Corruption: The Facts, Foreign Policy, 107 (Washington, D.C.:

Carnegie Endowment for International Peace).

Kaufmann, D., 2005: Myths and Realities of Governance and Corruption, http://siteresources.worldbank.org/INTWBIGOVANTCOR/Resources/21_Governance_and_ Corruption_Kaufmann.pdf. (Washington D.C.: World Bank).

Kaufmann, D., A. Kraay, and M. Mastruzzi, 2006: Governance Matters V: Aggregate and Individual Governance Indicators for 1996-2005. draft. (Washington D.C.: World Bank).

Keefer, P.; Knack, S., 1995: Polarization, Property Rights and the Links between Inequality and Growth, IRIS Center Working Paper \#153, University of Maryland, College Park.

Martijn, J.K. and C. Tsangarides, 2006: "Trade Reform in the CEMAC: Developments and Opportunities. Selected Issues,” IMF Country Report No.06/309, August 2006. (Washington: International Monetary Fund).

La Palombara, J., 1994: The Structural aspects of corruption, in Corruption and Democracy, Institute for Constitutional and Legislative Policy, Budapest.

La Porta, R. Lopez-de-Silanes, F., Shleifer, A., 1999: Corporate ownership around the world, Journal of Finance 54, 471-517.

Le, Q. and M. Rishi, 2005: Corruption and Capital Flight: An Empirical Assessment. Forthcoming International Economic Journal.

Leite, C. and J. Weidmann, 1999: Does Mother Nature Corrupt? Natural Resources, Corruption, and Economic Growth, IMF Working Paper WP/99/85. (Washington D.C. International Monetary Fund).

Mauro, P., 1995: Corruption and Growth, Quarterly Journal of Economics 110/3, 681-712.

Mauro, P., 1997: Why Worry About Corruption?, Economic Issues, 6 - 1997 (Washington D.C. International Monetary Fund). 
Mookherjee, D. and I. Png, 1995: Corruptible Law Enforcers: How Should They Be Compensated?, Economic Journal, Royal Economic Society, vol. 105/428, 145-59.

Murphy, K., A. Shleifer, and R. Vishny, 1991: The Allocation of Talent: Implications for Growth, The Quarterly Journal of Economics, 106(2), 503-30.

Ng, F. and A. Yeats, 1999: Good Governance and Trade Policy: Are They the Keys to Africa's Global Integration and Growth?, World Bank Policy Research Working Paper Number 2038, (Washington: The World Bank).

Oliva, M., 2007: “Trade Policies in Congo," mimeo, (Washington: International Monetary Fund).

Rauch, J. and P. Evans, 2000: Bureaucratic Structure and Bureaucratic Performance in Less Developed Countries, Journal of Public Economics 75, 49-71.

Rose-Ackerman, S. 1999: 'Grand' Corruption and the Ethics of Global Business Yale Law School, Program for Studies in Law, Economics and Public Policy, Working Paper No. 221.

Ross, M., 2001: Timber Booms and Institutional Breakdown in Southeast Asia. (New York: Cambridge University Press).

Sala-i-Martin, X. and A. Subramanian, 2003: Addressing the Natural Resource Curse: An Illustration from Nigeria, IMF Working Paper 03/019. (Washington D.C. International Monetary Fund).

Svensson, J., 1998: Foreign Aid and Rent-Seeking. World Bank. February. Mimeo, forthcoming in the Journal of International Economics.

Smarzynska, J. and S.-J. Wei, 2002: Corruption and Cross-Border Investment: Firm Level Evidence, William Davidson Institute Working Paper No. 494.

Tanzi, V. and H. Davoodi, 2000: Corruption, Growth, and Public Finances. IMF Working Paper 00/182. (Washington: International Monetary Fund).

UNDP and the Ministry in charge of State Control, 2003: La Corruption et la Fraude en Republique du Congo.

Van Rijckeghem, C. and B. Weder, 2001: Bureaucratic corruption and the rate of temptation: do wages in the civil service affect corruption, and by how much?, Journal of Development Economics, Elsevier, vol. 65/2, 307-331. 
Wei, S.-J., 1999: How Taxing is Corruption on International Investors? The Review of Economics and Statistics, Vol. 81/4, 1-12.

Wei, S.-J., 2000: Bribery in the Economies: Grease or Sand? Harvard University, NBER, and the World Bank. Mimeo. (Washington D.C.: World Bank).

Wei, J.-W., Y. Wu, 2002: "Negative Alchemy? Corruption, Composition of Capital Flows, and Currency Crises," in Preventing Currency Crises in Emerging Markets, ed. By Sebastian Edwards and Jeffrey Frankel, pp. 461-501 (Chicago: University of Chicago Press). 


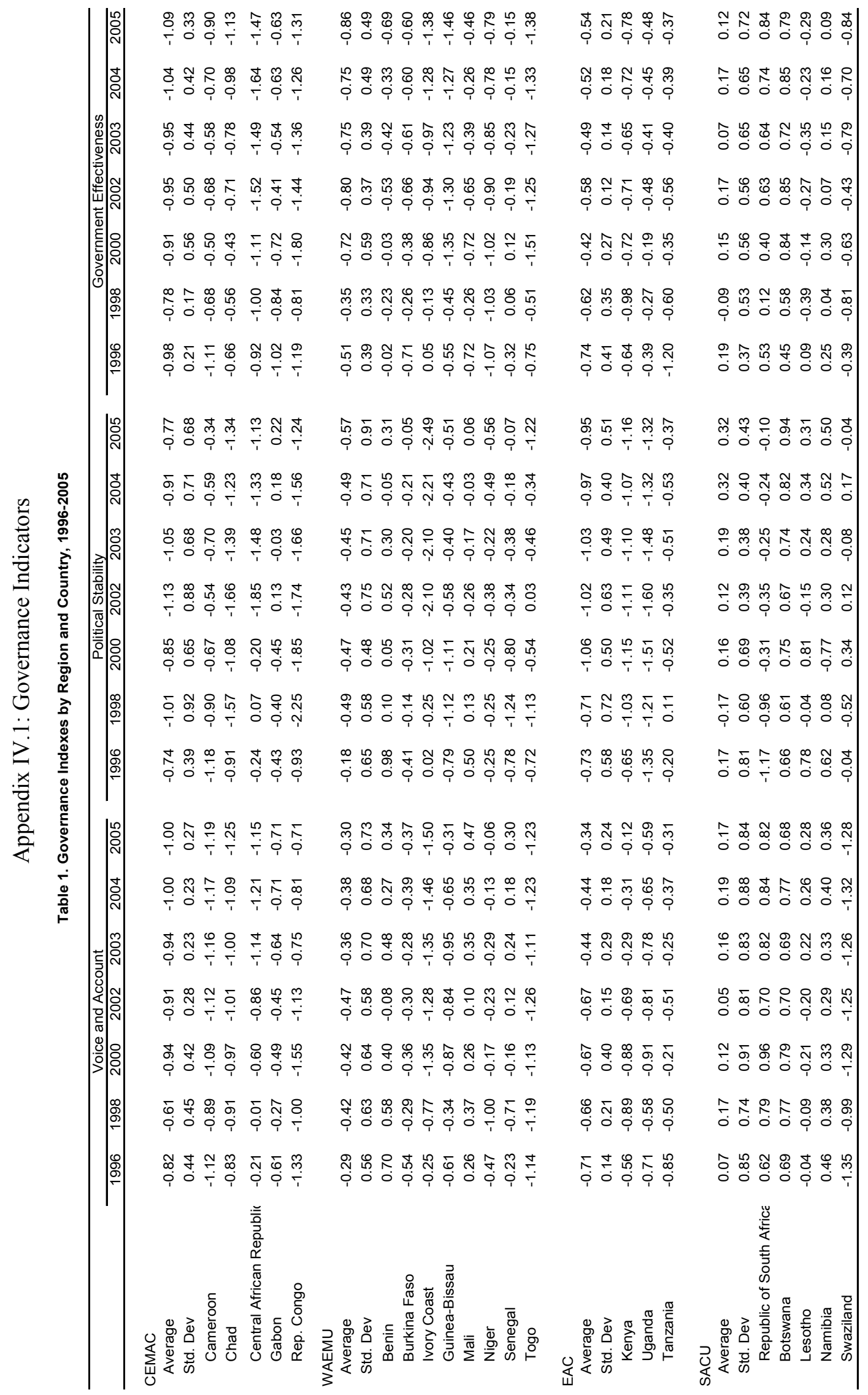




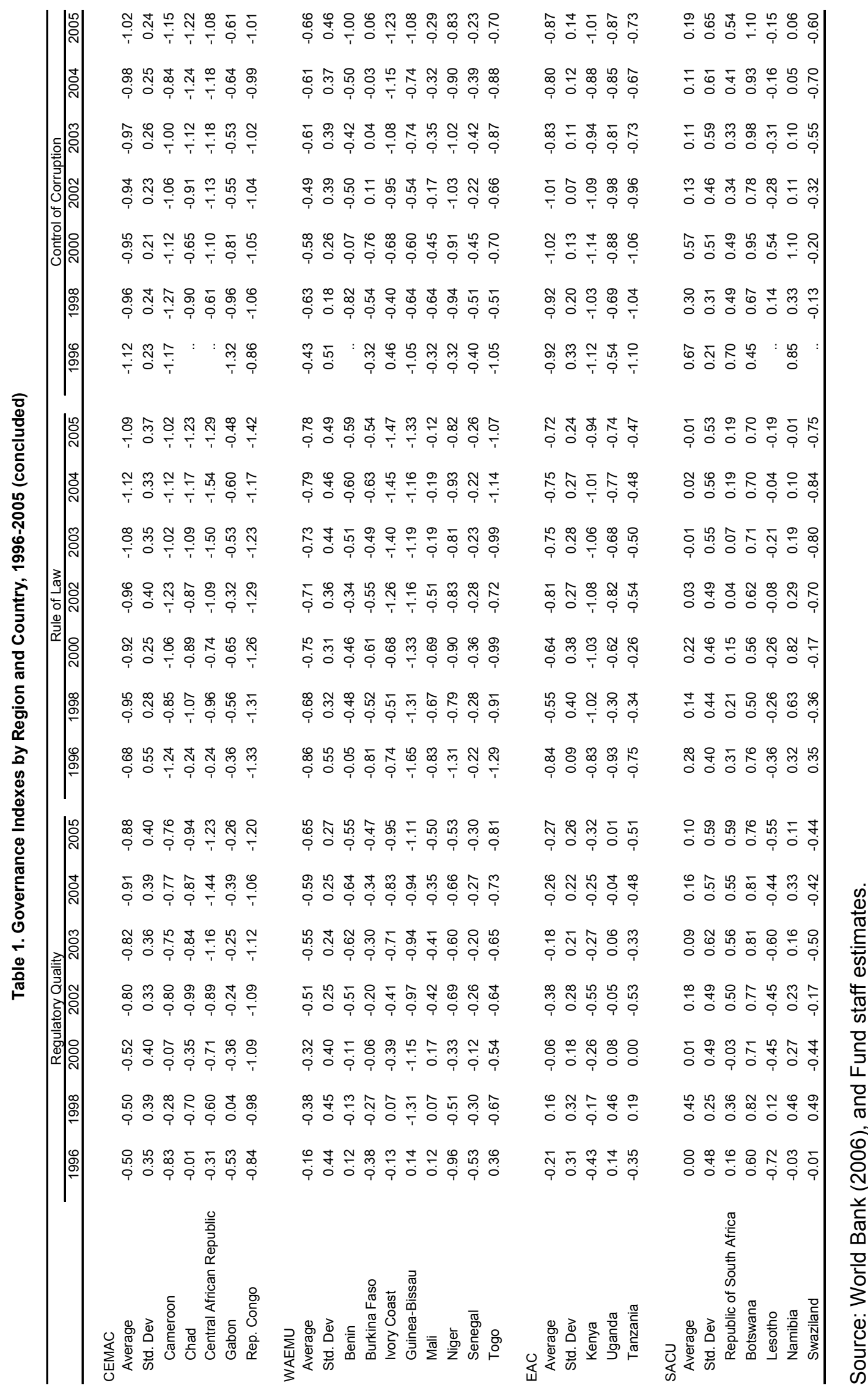




\section{Appendix IV.2: Defining Governance}

Governance can be defined as the process and institutions by which authority in a country is exercised. The World Bank 2006 governance indicators capture six aspects of good governance. The operational notion of governance includes (Kaufmann 2001 and 2006):

Dimension 1: Measures of the process by which governments are chosen, held accountable, monitored and replaced. These include the indexes of (i) voice and external accountability, which measures political, civil and human rights and the extent to which citizens are allowed to participate in the selection of their government; and of (ii) political stability and absence of violence, crime and terror, which measure perceptions of the likelihood the government will be destabilized and of violent threats including terrorism;

$>$ Dimension 2: Measures of the capacity of governments to manage domestic resources, to provide services efficiently and to implement sound policies and regulations. These include the indexes of (i) government effectiveness, which control for perceptions of the quality of public and civil services, the degree of independence from political pressures, the credibility of the government's commitment to its policies; and of (ii) regulatory burden, which controls for the ability of the authorities to formulate and implement sound policies and promote the development of the private sector.

Dimension 3: Measures of the respect for the institutions that govern economic and social interactions. This include the indexes of (i) the rule of law, that measures the perception about the respect and enforcement of the rules of the society, contracts, courts' outcomes; and of (ii) control of corruption, which controls for perceptions that public positions are being used for private gain. 


\section{Financial Sector Development Strategy ${ }^{27}$}

\section{A. Introduction}

79. This chapter outlines a strategy to strengthen Congo's financial sector. The first section reviews the crucial importance of a sound financial sector on growth; the second section presents an overview of the financial sector; and the last one recommends ways to increase consumer access to financial services and improve financial sector soundness.

\section{The state of a country's financial sector can significantly affect its growth. A}

sound, deep, and efficient financial sector mobilizes savings, allows such savings to be put to productive use, monitors the borrowing and enforces corporate controls, facilitates risk management, and expedites contracts and transactions in goods and services (Levine, 1997). An underdeveloped financial sector is a serious obstacle to growth. Even when a country has met other preconditions for economic growth, such as a high level of educational attainment, inadequate financial development can trap the country in poverty because it creates a vicious circle of low competition and limited financial intermediation (Berthelemy and Varoudakis, 1996). It is pivotal, therefore, for a country to build its financial sector.

\section{There are several mutually reinforcing aspects to financial sector development.} Development may depend on a much diversified range of financial institutions and financial products, a more efficient and competitive operating environment, a sounder legal system, wider access to financial services, and a sounder and more stable financial sector. These aspects are interwoven. For example, a wider range of financial products demands a more sophisticated legal system, which in turn encourages innovation in financial products and improves their liquidity. Among these aspects, two of them are of particular importance: wide access to financial services, and a sound and stable financial sector.

\section{Improving access to financial services is essential for low-income countries for} economic growth and to reduce poverty. Financial services can help smooth consumption by providing a cushion against income fluctuations. They can also be a convenient vehicle for saving for costly expenditures such as education, health, and productivity-enhancing equipment. Access to credit encourages private sector, especially small and medium enterprises (SMEs), to create and expand businesses, setting the country on the path to longterm economic growth. Credit allocated to education and health services can generate future productivity.

83. A sound and stable financial sector ensures long-term sustainability. Experience suggests that there is a nonlinear relationship between the vulnerability and the size of a financial sector. When the financial sector is small, with few players and an illiquid interbank

${ }^{27}$ Prepared by Joseph Karangwa and Yinqiu Lu. 
market, problems in one bank do not necessarily affect other banks. In a large and mature financial market with a variety of players and products, risks can be priced and sold to those capable of managing and hedging them. A medium-sized financial system is most vulnerable because it is not large enough to effectively diversify risk. Hence, when a country's access to financial services has been increasing and its financial sector is evolving from small to medium-sized, measures to safeguard the stability and soundness of the financial system are crucial to keeping the evolution sustainable.

\section{A good legal and efficient environment is another factor contributing to} financial sector development. A sound legal system lowers the cost of enforcing contracts and improves recovery of collateral. It reduces the credit risk and makes financial institutions more willing to lend. A diversified range of financial institutions and products means more choices for households and SMEs to allocate savings and secure investment funds. It also helps financial institutions diversify risk. An efficient and competitive operating environment increases access by reducing the cost of services.

\section{B. Congo's Financial Sector: An Overview}

\section{Features of the Financial Sector}

85. The Congolese financial sector consists of 4 commercial banks, a governmentowned postal savings network, 3 insurance companies, 2 pension funds, and 75 microfinance institutions (Table V.1). Its total assets in 2005 amounted to $10 \frac{1}{2}$ percent of GDP. The banking system accounts for 87 percent of total financial sector assets. The four commercial banks are privately owned; ${ }^{28}$ and the government holds only a small share of capital in three of them. Three are foreign-owned and account for 57 percent of the total balance sheet of the banking sector. The fourth one, La Congolaise de Banque (LCB), ${ }^{29}$ has 75 percent of its capital controlled by domestic private interests, but the management of the bank has been entrusted to a foreign strategic partner, the Banque Marocaine du Commerce Extérieur (BMCE), which holds 25 percent of the capital. At year-end 2005, the largest bank, BGFI-Congo, accounted for about 30 percent of deposits and loans, while the share of total assets of the financial sector held by microfinance institutions was 10.5 percent. One of the three insurance companies is government owned; the other two are privately owned.

\section{The financial sector is underdeveloped, and financial intermediation is lower} than in other sub-Saharan African countries (Table V.2). The ratio of total financial sector assets to GDP and broad money to GDP were well below the averages in the CFA

\footnotetext{
${ }^{28}$ Including COFIPA bank, which was privatized in September 2006.

${ }^{29}$ La Congolaise de Banque was created in June 2004 following the privatization of the Crédit pour l'Agriculture, l'Industrie et le Commerce (CAIC).
} 
franc region and other sub-Saharan African countries. Credit to the private sector in Congo represented 3.0 percent of GDP in 2005, as opposed to 7.4 percent in CEMAC countries. The interbank market is underdeveloped, as the volume traded on the national money market averaged only CFAF 19 billion ( 0.9 percent of GDP) in 2002-05, mainly because most banks had excess liquidity.

Table V.1. Republic of Congo: Financial System Structure, 2005

\begin{tabular}{|c|c|c|c|c|c|}
\hline & \multicolumn{2}{|c|}{ Number of } & \multicolumn{3}{|c|}{ Financial system assets } \\
\hline & Institutions & Branches & CFAF billion & $\begin{array}{c}\text { Percent of } \\
\text { financial system }\end{array}$ & $\begin{array}{l}\text { Percent of } \\
\text { GDP }\end{array}$ \\
\hline Commercial banks & 91 & 22 & 321.2 & 97.6 & 10.2 \\
\hline Commercial banks & 4 & 22 & 286.7 & 87.1 & 9.1 \\
\hline Large commercial banks & 4 & $\ldots$ & 286.7 & 87.1 & 9.1 \\
\hline Large domestic bank & 1 & $\ldots$ & 90.4 & 27.5 & 2.9 \\
\hline Major foreign-owned banks & 2 & $\ldots$ & 163.5 & 49.7 & 5.2 \\
\hline State owned & 1 & $\ldots$ & 32.8 & 10.0 & 1.0 \\
\hline Microfinance institutions & 86 & $\ldots$ & 34.5 & 10.5 & 1.1 \\
\hline Development banks & $\ldots$ & $\ldots$ & $\ldots$ & $\ldots$ & $\ldots$ \\
\hline Merchant banks & 0 & $\cdots$ & $\cdots$ & $\cdots$ & $\ldots$ \\
\hline Post Office Bank & 1 & $\ldots$ & $\ldots$ & $\ldots$ & $\ldots$ \\
\hline Rural banks & 0 & 0 & 0.0 & 0.0 & 0.0 \\
\hline Insurance companies & 2 & $\ldots$ & 8.0 & 2.4 & 0.3 \\
\hline Insurance companies & 2 & $\ldots$ & 8.0 & 2.4 & 0.3 \\
\hline State pension fund & .. & $\ldots$ & $\ldots$ & $\ldots$ & $\ldots$ \\
\hline Other insurance companies ${ }^{1}$ & 2 & $\ldots$ & 8.0 & 2.4 & $\ldots$ \\
\hline Reinsurance companies & 0 & 0 & 0.0 & 0.0 & 0.0 \\
\hline $\begin{array}{l}\text { Other non-fbank financial } \\
\text { institutions }\end{array}$ & 0 & $\ldots$ & 0.0 & 0.0 & 0.0 \\
\hline Total financial sector & 93.0 & $\ldots$ & 329.2 & 100.0 & 10.5 \\
\hline
\end{tabular}

Sources: COBAC, Ministry of Economy, Finance and Budget; and Fund staff estimates.

${ }^{1}$ Information as of end-2003. 
Table V.2. Selected Financial Indicators, 2004

\begin{tabular}{|c|c|c|c|c|c|c|}
\hline & $\begin{array}{c}\text { Number of } \\
\text { Comm. Banks }\end{array}$ & $\begin{array}{l}\text { M2/GDP } \\
\text { (percent) }\end{array}$ & $\begin{array}{c}\text { Bank } \\
\text { Assets/GDP } \\
\text { (percent) }\end{array}$ & $\begin{array}{l}\text { Private Sector } \\
\text { Credit/GDP } \\
\text { (percent) }\end{array}$ & $\begin{array}{c}\text { Central } \\
\text { Government } \\
\text { Credit/GDP } \\
\text { (percent) }\end{array}$ & $\begin{array}{l}\text { Population with } \\
\text { Formal Bank } \\
\text { Account (percent) }\end{array}$ \\
\hline The Republic of Congo & 4 & 14.6 & 8.9 & 3.2 & 0.9 & 2.7 \\
\hline SSA & 30 & 42.7 & 67.4 & 39.5 & 6.1 & 26.8 \\
\hline SSA MIC & 30 & 59.9 & 96 & 70.2 & 6.7 & 41.2 \\
\hline SSA LIC & 30 & 27.6 & 38.3 & 12.3 & 5.5 & 7.6 \\
\hline Oil-exporting countries & 53 & 20 & 33.6 & 11.1 & 3.5 & 7.1 \\
\hline Oil-importing countries & 23 & 49.4 & 77.5 & 47.6 & 6.8 & 33.9 \\
\hline CFA countries & 9 & 20.4 & 16.1 & 11.8 & 1.5 & 3.9 \\
\hline Non-CFA countries & 34 & 46.5 & 72.5 & 44 & 6.8 & 29.2 \\
\hline
\end{tabular}

Source: Sub-Saharan Africa Regional Outlook (2006).

87. Household access to savings facilities is low. Only 2.7 percent of Congo's population in 2004 had bank accounts (5.1 percent had microfinance institution (MFI) accounts). There are only 22 bank branches in the whole country. Banks tend to charge high fees for opening and maintaining accounts, and minimum balance requirements keep many small-scale savers from opening accounts. ${ }^{30}$ Customers with bank accounts are generally wealthy. The average size of bank savings accounts is about three times per capita income. Poverty and lack of paved roads also limit both demand for bank accounts and the expansion of branches in rural areas.

\section{Consumers have limited access to credit and face high financing costs. As}

indicated above, bank credit to the private sector in 2005 was just 3.0 percent of GDP. Real lending rates are very high, averaging 15.5 percent (based on maximum lending rates). The main reasons for high lending costs are lack of competition and the risks associated with the high cost of doing business in Congo (Table V.3). The World Bank's Doing Business survey $^{31}$ ranks Congo near the bottom (171 out of 175 economies) in terms of the ease of doing business (Table I.1). Credit information about borrowers' financial status is inadequate. The availability of collateral is limited, and there is no up-to-date property registry. In addition, the process of enforcing contracts and recovering losses is hampered by an inadequate legal system.

\footnotetext{
${ }^{30}$ Some banks require customers to deposit at least CFAF 200,000 (one-fifth of per capita GDP) to open a checking account and at least CFAF 1,000,000 to open a savings account that maintains a minimum balance of CFAF 500,000.

${ }^{31}$ The World Bank, Doing Business-benchmarking business regulations, http://www.doingbusiness.org.
} 
Table V.3. CEMAC: Banking Concentration, 2002-05

\begin{tabular}{lcc}
\hline & $\mathrm{HH}$ Index 2002 & $\mathrm{HH}$ Index 2005 \\
\hline Cameroon & 1,621 & 1,416 \\
Central African Republic & 3,673 & 3,421 \\
Congo & 3,098 & 2,689 \\
Gabon & 2,716 & 2,734 \\
Equatorial Guinea & 4,346 & 3,832 \\
Chad & 2,154 & 1,933 \\
\hline
\end{tabular}

Note: $1,000-2,000=$ moderate concentration; $>2,000=$ high concentration. The index is calculated by summing up the squared relative market shares (in percentage points) of all the banks: INDEX $=\sum_{n}^{1} X_{n}^{2}$, where $\mathrm{X}$ is the market share in percentage points.

Sources: International Monetary Fund (2006).

\section{Macroeconomic Factors Affecting the Health of the Banking System}

89. The oil sector dominates the Congolese economy. The country's heavy dependence on oil exports leaves it vulnerable to external shocks, especially oil price volatility. Oil production is located offshore and managed by joint ventures between foreign companies and the national oil company (Société Nationale des Pétroles du Congo, SNPC). Ancillary oilrelated services are largely run by foreign groups, which import most supplies. The non-oil sector comprises a mixture of forestry, traditional agriculture, services, and a relatively large public administration. Congo's forests, which cover about half of the country, account for less than 5 percent of output and two-thirds of non-oil exports. Agriculture, which employs about a third of the population, accounts for about 5 percent of GDP. It consists mainly of subsistence activities by smallholders, with relatively little commercialization (in part because of poor access roads) and limited export activities. Volatility in world oil prices, under the fixed exchange rate regime, has thus led to volatility in the external current account and in public finance generally. Even though the government's share of loans in the banking sector has decreased from 23.4 percent in 2002 to 2.8 percent in 2005, a sharp drop in oil prices could increase that share and keep government suppliers and employees from meeting their financial obligations.

90. Given the regional monetary arrangements, and the lackluster performance of the non-oil economy, the government's role as a client of the banking system is crucial to macroeconomic stability. ${ }^{32}$ Government deposits in 2002-05 accounted for about 7.3

\footnotetext{
${ }^{32}$ Congo is a member of the Communauté Economique et Monétaire des Pays de l'Afrique Centrale (CEMAC), an economic and monetary union of six countries. The CEMAC countries' common currency is the CFA franc, which is issued by the common central bank, the Banque des Etats de l'Afrique Centrale (BEAC), and is pegged to the euro. Banking supervision in the CEMAC region is conducted by a common supervisory agency, the Commission Bancaire de l'Afrique Centrale (COBAC). As a consequence of belonging to an economic and monetary union with a fixed exchange rate regime, fiscal policy is the key instrument for the Congo and other members of the CEMAC to ensure macroeconomic stability.
} 
percent of total bank deposits (compared with 13.5 percent in the CEMAC), while bank credit to the government represented 15 percent of total loans (compared with only 5.5 percent in the CEMAC region). Therefore, potential government arrears, either to banks or to suppliers that use banks, could have a significant impact on the quality of bank loan portfolios.

\section{Performance of the Financing Sector}

\section{The Banking System}

\section{Deposit liabilities are the main source of financing to Congolese banks}

(Figure V.1). Deposits in 2002-05 represented 94 percent of the banking system balance sheet (compared with 86 percent for the CEMAC region as a whole). About 80 percent of deposits in Congolese banks are short term, compared with an average of 70 percent in the CEMAC region (Table V.4). The high level of short-term deposits limits the availability of funding for long-term financing. The remainder of the banking system liabilities consists mainly of capital and provision for doubtful loans. Congolese banks are less capitalized than banks in countries in the CEMAC region; and capital at Congolese banks represents only about 6 percent of the banking sector's balance sheet, compared with 14 percent for the CEMAC.

92. Less than a third of bank resources finance credit (compared with almost half in the CEMAC region), while most bank resources (66 percent) are held in liquid assets (Figure V.2). The low level of credit relative to bank resources reflects (i) weak economic activity in the non-oil sector, which limits lending opportunities; (ii) the high cost of credit stemming in part from limited competition among banks (see below); and (iii) unfavorable legal and judiciary procedures, which make it harder for banks to recover delinquent loans and foreclose on collateral. Such conditions make banks reluctant to extend long-term loans; and short-term loans account for the bulk of their lending. 
Figure V.1. Structure of Resources, as of end-2005

(Percent)

\section{Congo}

Permanent capital and other

6.3

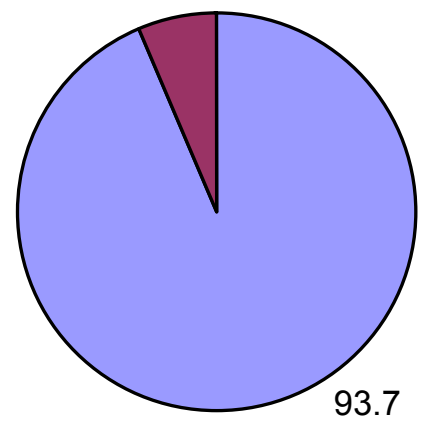

Customers deposits
CEMAC

Permanent capital and other

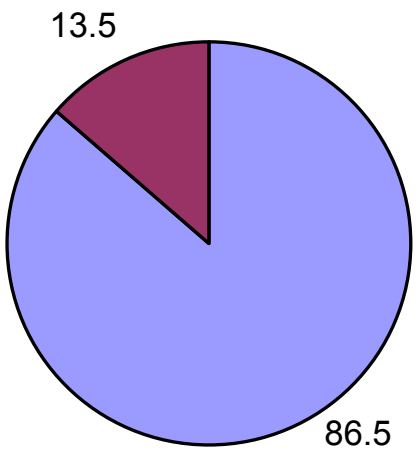

Customers deposits

Source: CEMAC.

Table V.4. Commercial Bank Deposit and Credit Structure, 2002-05

\begin{tabular}{|c|c|c|c|c|c|c|c|c|}
\hline & \multicolumn{4}{|c|}{ Republic of Congo } & \multicolumn{4}{|c|}{ CEMAC } \\
\hline & 2002 & 2003 & 2004 & 2005 & 2002 & 2003 & 2004 & 2005 \\
\hline Customers deposits by type of deposits & 100.0 & 100.0 & 100.0 & 100.0 & 100.0 & 100.0 & 100.0 & 100.0 \\
\hline Sight deposits & 80.3 & 74.2 & 80.4 & 84.1 & 69.6 & 68.0 & 71.3 & 74.2 \\
\hline Term deposits & 12.0 & 20.6 & 15.8 & 12.5 & 17.7 & 19.9 & 16.9 & 15.0 \\
\hline Other accounts & 7.7 & 5.2 & 3.8 & 3.4 & 12.7 & 12.1 & 11.8 & 10.8 \\
\hline Customers deposits by type of depositor & 100.0 & 100.0 & 100.0 & 100.0 & 100.0 & 100.0 & 100.0 & 100.0 \\
\hline Central government & 8.2 & 8.8 & 5.3 & 16.9 & 14.1 & 11.6 & 11.3 & 16.3 \\
\hline Public entreprises & 26.5 & 12.5 & 14.5 & 9.1 & 6.9 & 6.2 & 5.0 & 4.3 \\
\hline Private & 55.8 & 71.6 & 65.4 & 67.0 & 71.3 & 75.3 & 75.8 & 73.0 \\
\hline Non-residents & 1.8 & 1.9 & 11.1 & 3.8 & 2.6 & 2.5 & 3.7 & 3.0 \\
\hline Undistributed deposits & 7.7 & 5.1 & 3.8 & 3.3 & 5.0 & 4.4 & 4.1 & 3.4 \\
\hline Credits by type of beneficiary (gross) & 100.0 & 100.0 & 100.0 & 100.0 & 100.0 & 100.0 & 100.0 & 100.0 \\
\hline o/w: Non-performing loans & 1.1 & 3.5 & 6.5 & 3.4 & 13.9 & 14.2 & 14.6 & 13.6 \\
\hline Credit to the government & 22.8 & 13.3 & 20.9 & 3.9 & 6.6 & 5.3 & 5.9 & 4.3 \\
\hline Credt to the economy & 75.3 & 84.9 & 77.2 & 91.9 & 90.4 & 90.7 & 87.7 & 90.7 \\
\hline Credit to public entreprises & 5.6 & 5.5 & 10.1 & 8.8 & 8.4 & 8.7 & 7.9 & 7.6 \\
\hline Credit to private sector & 69.8 & 79.4 & 67.1 & 83.1 & 82.1 & 81.9 & 79.8 & 83.1 \\
\hline Credit to non-resident & 0.6 & 0.4 & 1.4 & 3.9 & 1.4 & 2.8 & 4.9 & 3.7 \\
\hline Leasing & 0.0 & 0.0 & 0.0 & 0.0 & 0.5 & 0.5 & 0.5 & 0.4 \\
\hline Other credits & 1.3 & 1.3 & 0.5 & 0.4 & 1.0 & 0.8 & 1.0 & 0.9 \\
\hline
\end{tabular}




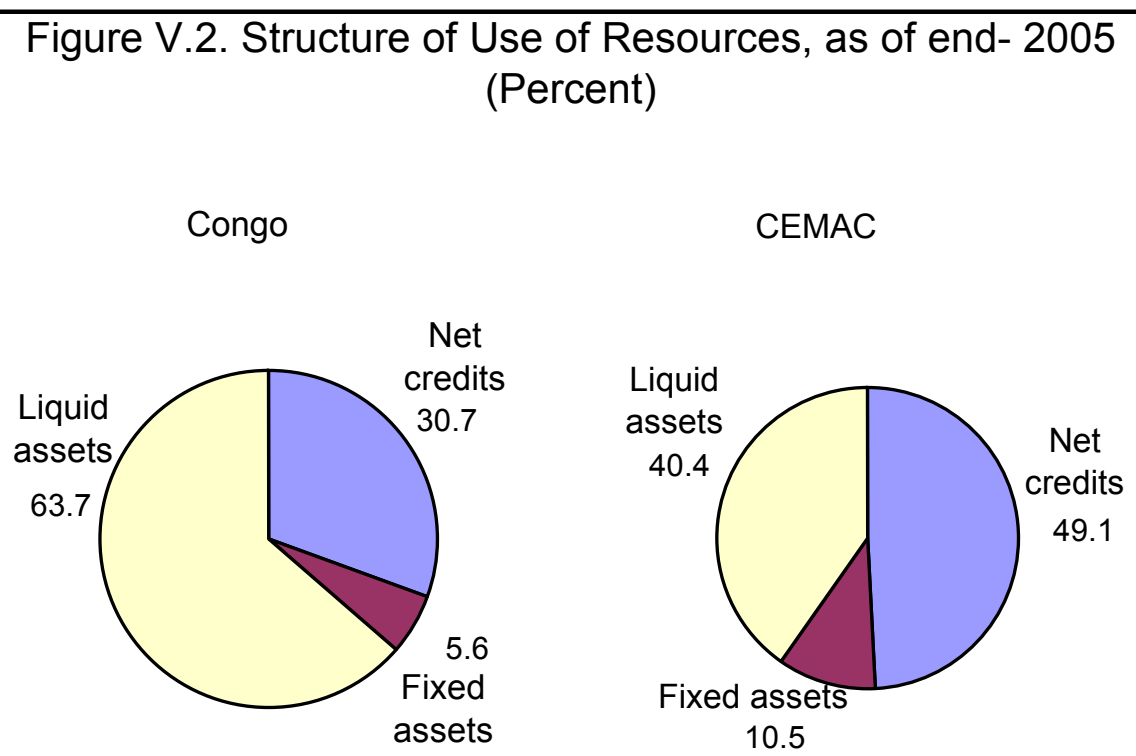

Source: CEMAC.

\section{Profitability}

93. Congolese banks are broadly profitable. Return on assets in 2002-05 averaged 2 percent, while return on equity exceeded 25 percent (Table V.5); the high level of the latter partly reflects the low capital base of the banking system. The high profitability of the Congolese banking system results from a strong interest margin of about 12 percent in 2001-05, compared with 9 percent for the CEMAC region. As indicated earlier, the high interest margin reflects limited interbank competition as well as risk pricing by banks. The quality of loan portfolios improved recently, with the ratio of nonperforming loans to total loans decreasing from 6.5 percent in 2004 to 3.5 percent in 2005. For the whole CEMAC region, these ratios were 14.6 percent and 13.6 percent, respectively. The provisioning of nonperforming loans also improved to 84 percent at year-end 2005, putting it on par with the CEMAC level (81 percent). 
Table V.5. Republic of Congo: Financial Soundness Indicators for the Banking Sector (Percent, at year's end, unless otherwise indicated)

\begin{tabular}{|c|c|c|c|c|c|}
\hline & 2001 & 2002 & 2003 & 2004 & 2005 \\
\hline \multicolumn{6}{|l|}{ Capital Adequacy } \\
\hline Regulatory capital to risk-weighted assets & $\ldots$ & 4.3 & 4.6 & 3.7 & 11.7 \\
\hline Percentage of banks greater or equal to 10 percent & $\ldots$ & 25 & 25 & 25 & 75 \\
\hline Percentage of banks below 10 and above 6 percent minimum & $\ldots$ & 0 & 0 & 25 & 25 \\
\hline Percentage of banks below 6 percent minimum & $\ldots$ & 75 & 75 & 50 & 0 \\
\hline Capital (net worth) to assets & $\ldots$ & 3.4 & 3.2 & 2.5 & 3.9 \\
\hline \multicolumn{6}{|l|}{ Asset quality } \\
\hline Foreign exchange loans to total loans & $\ldots$ & $\ldots$ & $\ldots$ & $\ldots$ & $\ldots$ \\
\hline Past-due loans to gross loans & $\ldots$ & & & & \\
\hline Nonperforming loans & $\ldots$ & 1.1 & 3.5 & 6.5 & 3.4 \\
\hline Watch-listed loans & $\ldots$ & $\ldots$ & $\ldots$ & $\ldots$ & $\ldots$ \\
\hline Provision as percent of past-due loans & $\ldots$ & 13.2 & 19.1 & 27.6 & 84.2 \\
\hline \multicolumn{6}{|l|}{ Earnings and profitability } \\
\hline Net profit (before tax)/net income & 41.2 & 5.1 & 1.5 & 8.1 & 22.6 \\
\hline Return on assets & $\ldots$ & 1.8 & 1.8 & 1.2 & 3.0 \\
\hline Return on equity & $\ldots$ & 42.7 & 20.7 & 12.8 & 33.4 \\
\hline Expense/income & 45.6 & 53.3 & 63.2 & 70.8 & 58.2 \\
\hline \multicolumn{6}{|l|}{ Interest rate spread (deposit money banks) } \\
\hline Lending rate minus demand deposit rates & 15.6 & 11.2 & 11.1 & 9.3 & 11.2 \\
\hline Saving deposit rates & $\ldots$ & $\ldots$ & $\ldots$ & $\ldots$ & $\ldots$ \\
\hline \multicolumn{6}{|l|}{ Liquidity } \\
\hline Liquid assets/total assets & $\ldots$ & 44.7 & 28.4 & 39.1 & 63.7 \\
\hline Liquid assets/short term liabilities & $\ldots$ & 163.5 & 106.9 & 163.6 & 272.5 \\
\hline Loan/deposits & $\ldots$ & 52.2 & 60.7 & 56.7 & 33.7 \\
\hline Liquid assets/total deposits & $\ldots$ & 48.1 & 27.7 & 42.3 & 68.0 \\
\hline Foreign exchange liabilities/total liabilities & $\ldots$ & $\ldots$ & $\ldots$ & $\ldots$ & $\ldots$ \\
\hline Excess reserves/Broad money & 11.6 & 9.9 & 13.0 & 15.6 & $\ldots$ \\
\hline \multicolumn{6}{|l|}{ Sensitivity to market risk } \\
\hline Net foreign exchange assets (liabilities) to shareholders' funds & $\ldots$ & $\ldots$ & $\ldots$ & $\ldots$ & $\ldots$ \\
\hline
\end{tabular}

\section{Compliance with Prudential Regulations}

94. The Congolese banking sector is fragile and highly susceptible to risk. The soundness of the banking system in the CEMAC region is assessed on the basis of prudential ratios set by the regional supervisory agency COBAC. This body sets a minimum riskweighted capital ratio and regulates liquidity, risk diversification, and maturity transformation. Financial soundness and performance indicators show that in the past two years, at least three of the four Congolese commercial banks frequently failed to comply with key solvency indicators based on capital adequacy ratios, though the majority complied with risk and liquidity indicators.

\section{The weak financial soundness is attributable mainly to insufficient capital} relative to liabilities, against the back of widespread compliance with the minimum capital requirement. At end-2005, none of the four banks complied with the prudential indicator on capital adequacy which requires a capital-risk-weighted ratio of 8 percent (Table V.6). Reflecting the low capital level, two banks failed to meet the required 100 percent fixed assets-to-capital ratio. With respect to credit risk concentration, all but one bank complied with the prudential limit on both individual risks and total large exposures. As a consequence of the high share of sight deposits in total bank deposits, two banks on average have failed to 
meet the prudential ratio on the transformation coefficient during 2003-05. On a more favorable note, all banks except one complied with the prudential limit on connected lending. ${ }^{33}$ Under the rating system of the COBAC, three banks were found in good condition at end-December 2005. The fourth bank was reported in a fragile situation, with a rating of 3 (Table V.7).

\section{Table V.6. Republic of Congo: Number of Banks Complying with Prudential Ratios}

\begin{tabular}{lcccccc}
\hline Prudential ratios & Dec. 02 & Jun. 03 & Dec. 03 & Jun. 04 & Dec. 04 & Dec. 05 \\
\hline Capital adequacy & 1 & 0 & 0 & 0 & 1 & 0 \\
Risk coverage & 1 & 1 & 1 & 2 & 3 & 4 \\
Ceiling on risks & 2 & 2 & 2 & 2 & 3 & 4 \\
Ceiling on individual risks & 1 & 0 & 0 & 0 & 1 & 1 \\
Fixed assets coverage & 2 & 0 & 1 & 1 & 2 & 2 \\
Liquidity & 2 & 4 & 4 & 3 & 4 & 4 \\
Transformation coefficient & 2 & 2 & 2 & 1 & 2 & 3 \\
Connected lending & 3 & 3 & 3 & 3 & 3 & 2 \\
Total number of banks & 4 & 4 & 4 & 4 & 4 & 4 \\
\hline
\end{tabular}

Source: $C O B A C$.

Table V.7. Banks' Rating in Congo and the CEMAC

\begin{tabular}{|c|c|c|c|c|c|c|}
\hline & \multicolumn{2}{|c|}{ Dec. 2003} & \multicolumn{2}{|c|}{ Dec. 2004} & \multicolumn{2}{|c|}{ Dec. 2005} \\
\hline & Congo & CEMAC & Congo & CEMAC & Congo & CEMAC \\
\hline Strong & 0 & 2 & 0 & 2 & 0 & 6 \\
\hline Good & 1 & 18 & 2 & 17 & 3 & 16 \\
\hline Slightly fragile & 0 & 1 & 0 & 3 & 0 & 1 \\
\hline Moderately fragile & 2 & 3 & 1 & 2 & 1 & 4 \\
\hline Highly fragile & 0 & 0 & 0 & 3 & 0 & 1 \\
\hline Critical & 0 & 1 & 0 & 0 & 0 & 1 \\
\hline Highly critical & 0 & 1 & 1 & 3 & 0 & 3 \\
\hline Not rated & 0 & 3 & 0 & 3 & 0 & 1 \\
\hline Total & 3 & 29 & 4 & 33 & 4 & 33 \\
\hline Average rating ${ }^{1}$ & 3B & 2 & 3B & $3 \mathrm{~A}$ & 2 & 2 \\
\hline
\end{tabular}

Source: COBAC.

${ }^{1} \mathrm{~A}$ rating of $1=$ Strong financial situation, $2=$ good financial situation; $3 \mathrm{~A}=$ light fragile financial situation, $3 B=$ fragile financial situation, $4 A=$ critical financial situation, and $4 B=$ very critical financial situation.

${ }^{33}$ Connected lending consists of lending to bank's shareholders, associates, managers, and employees. Banking system regulations limit connected lending to 15 percent of capital. 


\section{Microfinance}

96. Microfinance activity in Congo began in 1984 with the creation of the Mutuelles d'Epargne et de Crédits (MUCODEC). Under CEMAC's harmonized regulations, adopted in 2003, the COBAC is responsible for external control of the microfinance sector. The number of microfinance institutions in Congo increased from 69 in 2001 to 75 in 2005 (Table V.8). Deposits with, and credits granted by, these institutions increased to 16 percent of total deposits and 8 percent of total credits of the financial system by year-end 2004, respectively. However, lending by microfinance institutions makes up only 25 percent of deposits, on average, mainly reflecting a cautious lending policy stance.

Table V.8. Recent Developments in Microfinance Activity

\begin{tabular}{|c|c|c|c|c|c|c|c|c|c|c|}
\hline & \multicolumn{2}{|c|}{$\begin{array}{l}\text { Number of } \\
\text { institutions }\end{array}$} & \multicolumn{2}{|c|}{$\begin{array}{c}\text { Number of } \\
\text { members }\end{array}$} & \multicolumn{2}{|c|}{$\begin{array}{c}\text { Capital } \\
\text { (CFAF millions) }\end{array}$} & \multicolumn{2}{|c|}{$\begin{array}{c}\text { Deposits } \\
\text { (CFAF millions) }\end{array}$} & \multicolumn{2}{|c|}{$\begin{array}{c}\text { Credits } \\
\text { (CFAF millions) }\end{array}$} \\
\hline & 2001 & 2005 & 2001 & 2005 & 2001 & 2003 & 2001 & 2005 & 2001 & 2005 \\
\hline Cameroon & 652 & 714 & 200,000 & 475,644 & 7,700 & 9,720 & 35,790 & 95,022 & 25,260 & 61,021 \\
\hline Equatorial Guinea & 2 & $\ldots$ & $\ldots$ & $\ldots$ & $\ldots$ & $\ldots$ & $\cdots$ & . & $\cdots$ & \\
\hline Congo & 69 & 75 & 138,000 & 155,835 & 211 & 2,480 & 15,010 & 50,361 & 2,080 & 7,632 \\
\hline Gabon & 14 & 4 & 2,500 & 4,739 & 12 & 12 & 40 & 17 & 50 & 1,228 \\
\hline Central African Rep. & 43 & 22 & 41,000 & 34,000 & 117 & 405 & 2,280 & 2,666 & 650 & 993 \\
\hline Tchad & 128 & 214 & 32,000 & 98,378 & 504 & 270 & 640 & 4,419 & 1,390 & 3,669 \\
\hline CEMAC & 908 & 1,029 & 413,500 & 768,596 & 8,544 & 12,887 & 53,760 & 152,485 & 29,430 & 74,543 \\
\hline
\end{tabular}

\section{The MUCODEC network dominates microfinance activity, with 41 percent of} microfinance institutions and close to 90 percent of total deposits and credits. The remarkable development of microfinance reflects (i) the population's low confidence in the banking system, particularly after successive bank failures in the 1990s and in early 2000, and (ii) limited access to traditional banking services, especially after restructured banks closed branches and cut back services.

98. Microfinance institutions continue to mobilize deposits, helping to deepen financial intermediation. Deposit mobilization by microfinance institutions increased to 1.2 percent of GDP in 2004, from 0.7 percent in 2003. Most microfinance institutions operate in Brazzaville and Pointe Noire; only a third operate in rural areas. Credits extended by microfinance institutions mostly finance consumption, reflecting the short-term nature of their resources. In 2004, for instance, 74 percent of the volume of credits extended by microfinance institutions supported consumption. In rural areas, microfinance activity contributes to poverty reduction through the financing of agriculture enterprises. It also promotes savings, increases monetization of the economy, and facilitates financial intermediation.

99. As in other CEMAC countries, the financial state of microfinance institutions is fragile and volatile. Because of low capitalization, microfinance institutions cannot expand and are vulnerable in other ways. Operating costs are high, yet their profit margins are low. In Congo, although the sector has surplus liquidity, MFIs cannot meet the funding needs of 
their members owing to the dominance of short-term deposits - on average only 25 percent of deposits are lent out. Accounts with maturities beyond six months account for less than 2 percent of total deposits. Over a third of MFIs are run by volunteers. So far, microfinance activities in the Congo have benefited from limited external technical assistance from the Agence Française de Développement (AFD), and International Fund for Agriculture and Development (IFAD). Only MUCODEC and the Caisse de Participation à la Promotion des Entreprises et à leur Développement (CAPPED) receive external financing.

\section{Insurance Sector}

100. Congo's three insurance companies account for a small share of the financial sector (only 2.4 percent of total assets, or 0.3 percent of GDP). Vehicle and transport insurance dominates the sector with 68 percent share of the market, while fire and other hazards insurance accounts for 13 percent (Table V.9). Life insurance still only accounts for about 0.7 percent of the market. The government-owned insurance company, which accounts for 62 percent of the market, is a critical financial situation and needs to be restructured.

Table V.9. Republic of Congo: Structure of Insurance Market, 2004

\begin{tabular}{lrr}
\hline & $\begin{array}{r}\text { Amount of premium } \\
\text { (CFAF billion) }\end{array}$ & Percent \\
\hline Car insurance & 4.6 & 54.4 \\
Transport insurance & 1.0 & 12.1 \\
Fire hazards and other damages & 1.3 & 15.5 \\
Other & 1.5 & 17.3 \\
o/w: Life insurance & 0.1 & 0.7 \\
Total & 8.4 & 100.0 \\
\end{tabular}

Source: Congolese authorities; and Fund staff estimates.

\section{Postal Savings Network}

101. The postal savings network is currently inoperative and almost bankrupt. At year-end 2004, about CFAF 7 billion (0.3 percent of GDP) was due to small depositors. The authorities are planning to restructure the postal system (including the postal savings network).

\section{Pension Funds}

102. Both the Caisse nationale de sécurité sociale (CNSS) which provides social security to private sector employees and the Caisse de retraite des fonctionnaires (CREF), which provides social security to civil servants, are facing serious financial difficulties. At year-end 2004, payment arrears of pension benefits payable by the CREF were estimated at about CFAF 90 billion (3.6 percent of GDP). The CREF was owed CFAF 
115 (4.6 percent of GDP) in contribution arrears (CFAF 62.5 billion by public enterprises and CFAF 52.5 billion by the Treasury). The World Bank is expected to provide technical assistance in restructuring these two pension funds.

\section{A Strategy to Improve Access to Financial Services}

\section{More Savings Facilities for Households}

103. The cost of financial services should be reduced. The first step would be to create a more competitive environment, which may force financial institutions to improve services and lower prices. In this regard, the ministry of finance may consider surrendering licensing right to the COBAC to lower the administrative barriers for new financial institutions to enter the market. A second step would be to encourage regional financial integration. Given that financial institutions are subject to economies of scale and scope, they can lower their operating costs by expanding their activities through the CEMAC region. This would diversify their loan portfolios and reduce their exposure to specific business sectors. For this reason, a single CEMAC banking license procedure was adopted in July 2001, which allows banks in the region to open branches in another member country. So far, though, no CEMAC institution has applied to COBAC for a regional single license. There are at least three obstacles to such licensing requests: (1) limited effectiveness of the single license procedure, (2) gaps in infrastructure and markets (e.g., shallow regional interbank market, no debt market, and a rudimentary payment system), and (3) reputational effects and consumer preferences. Because these obstacles are at the regional level, the authorities might cooperate with other regional member countries to address these hurdles and pave the way for regional financial integration.

\section{Promoting habit formation in consumption of financial services would increase}

the use of banking services. Many households are unaware of the types of services available to them. The authorities might use public awareness campaigns to promote the concepts of saving and credit, and the role of financial institutions. The authorities might also distribute savings books to civil servants and encourage them to use banking services. To keep civil servants from withdrawing cash right after payday, ${ }^{34}$ a practice that adds to bank costs, banks might design contractual savings vehicles for consumers who do not have liquidity constraints. To promote credibility and transparency in the financial sector, COBAC might also encourage financial institutions to publish their audited financial reports according to international accounting standards. Greater bank transparency could also help expedite implementation of a deposit guarantee fund in Central Africa (Fonds de Garantie des Dépôts en Afrique Centrale (FOGADAC)), which in turn would promote a credit culture.

\footnotetext{
${ }^{34}$ The authors thank Jerome Vacher for pointing this out.
} 
105. Better infrastructure such as improved transport systems, new technology, and well-functioning payment system will considerably broaden access. Improved transportation would make financial services more accessible. Banks would also be more willing to open branches in rural areas, which could result in higher growth and poverty reduction. ${ }^{35}$ New technology, such as ATM machines, point-of-sale machines, and electronic bank cards, can lower the transport and transaction costs of financial services. Access to ATM machines, for example, could reduce the costs arising from civil servants lining up at banks after each payday. In Congo, one of the most urbanized countries in Africa, such products could be cost effective. In addition, well-functioning payment systems are needed to tap this new financial services technology. Retail payment systems and regional real-time gross settlement procedures in CEMAC are under construction, though lack of experience, capacity, and coordination at the BEAC have delayed implementation. There is no senior body responsible for all aspects of the payment systems. Problems could arise in information dissemination between the national units and the region. An electricity breakdown, in particular, could jeopardize the functioning of the Congolese payment unit.

\section{Credit to Private Sector}

106. More appropriate pricing of credit would encourage bank lending. Of the few profitable businesses outside of the oil sector, most are financed from abroad. The floor on deposit rates and ceiling for lending rates set by the BEAC may be out of line with market fundamentals. Hence, banks deposit excess liquidity in the central bank rather than to lend. As suggested by the CEMAC FSSA, the floor on deposit rates may be lowered, and the ceiling on lending rates may be increased without reaching usurious levels.

\section{To better assess the credit risk, banks need the reliable credit information,} suitable collateral, efficient property registry system, and a strong judicial system that enforces contract. However, in Congo, financial institutions find it difficult to assess creditworthiness because information from the Centrale des Risques is limited and standards for accounting and auditing practices are poor, putting the accuracy of financial statements in doubt. In terms of collateral, currently, farm production is on such a small scale that it is difficult for farmers to use their products as collateral. Moreover, Congo's record of property registry and contract enforcement compares poorly with other countries (see Table I.1). Banks have little confidence in the legal system and are critical of the complexity of Organization for the Harmonization of African Business Law (OHADA) (CEMAC FSSA, 2006).

\footnotetext{
${ }^{35}$ The link between expanding branches to rural areas and its impact on growth and poverty reduction can be found in Burgess and Pande (2003).
} 
108. Accordingly, the authorities might encourage the formation of an effective credit bureau to collect credit information about both SMEs and individual borrowers. Credit information should include not only default history but also standardized ratings of creditworthiness based on a basic rating system. The national association of MFIs for Congo is planning to set up a credit information bureau. However, instead of setting up a parallel credit bureau, the BEAC might encourage the association to join in the Centrale des Risques, through which the information is shared not only by banks but also by nonbank financial institutions in the region. Acknowledging the importance of improving accounting practices, the authorities might consider requiring adherence to the OHADA accounting system. At the same time, the authorities might revise and enforce their regulation of the accounting profession to improve the quality and transparency of accounting practices.

\section{The authorities might encourage farmers to form cooperatives, which in turn} can set up warehouses that enable the farmers to use warehouse receipts as collateral. This practice has worked well in Madagascar (Sacerdoti, 2005). The authorities might also encourage large agricultural marketing companies to obtain large long-term loans and redistribute them to individual farmers for longer-term investment.

\section{As for the hurdles in the property registry and contract enforcement, the} authorities might identify the main costs of the property registry and then reform the property registry system to streamline the whole process. They might also identify and alleviate problems with contract enforcement and allocate more resources to train judges in commercial, financial, and credit-related legal matters.

\section{Developing capital markets can widen access to financial services. Capital} markets provide savers with a variety of investment choices with long maturities. Companies can raise long-term funds from capital markets at a lower cost than from banks. Pension funds and insurance companies can invest in capital markets to manage duration of their portfolios. Developing capital markets takes time, and it requires appropriate sequencing and financial sector deepening as well as a sound macroeconomic environment, high income levels, transparent institutions, law and order, and good governance.

112. Stock market activity is organized at the regional level. Two stock exchangesthe Douala Stock Exchange (DSX) in Cameroon and the Central African Stock Exchange (BVMAC) in Gabon - provide limited capital liquidity. The former was recapitalized in 2005. The BVMAC is also facing capital constraints. Nevertheless, the Congolese authorities might educate companies about the role played by stock exchanges and promote transparency in business operations.

113. A bond market could be established with treasury bonds. The yield curve on treasury bonds would set a benchmark for pricing corporate bonds. A wide spectrum of maturities of treasury bonds is conducive to the development of other fixed-income products. Again, it takes time to develop a yield curve. Nevertheless, the authorities might start to test 
the debt market by swapping government loans held by banks with short-term treasury papers. If possible, the authorities might adopt a system of primary dealers to boost marketmaking capacity and liquidity in the secondary market. Banks could use these papers as collateral in interbank operations, and repo (repurchase agreement) activities could be developed. Of course, efficient collateral recovery procedures are required to smooth these activities. Since all the members of CEMAC have adopted the CFA franc, the Congolese authorities could market treasury papers throughout the region.

\section{The Role of Microfinance Institutions}

\section{The role played by MFIs could be strengthened to tap their flexibility in} providing financial services. MFIs mostly serve poor and rural households and the informal private sectors. They can provide loans to SMEs that are not able to meet lending criteria set by traditional banks; therefore, they play an important role in promoting entrepreneurship and economic development. MFIs are flexible in collecting and mobilizing savings because the limits for deposits and loans can be easily adjusted to meet local needs. In Ghana, the MFIs have expanded the susu collector ${ }^{36}$ function with "mobile banking" services that both accept savings and provide loans (Basu, Blavy, and Yulek, 2004).

115. Several measures may help increase the role of MFIs. The Ministry of Small and Medium-sized Enterprises is negotiating with the MUCODECs to create a program to finance small enterprises and handicraft producers, and it has established a guarantee fund to improve SMEs' access to credit. However, the fund's total budget to constitute guarantees and cover operating costs is CFAF 200 million, a small amount compared with the average financing needs of CFAF 50 million for small enterprises and CFAF 250 million for medium-sized ones. Therefore, no banks will accept this public guarantee. Nevertheless, the ministry, the National Association of MFIs, BEAC, and COBAC might promote closer cooperation between commercial banks and MFIs. For example, they might encourage banks to simplify procedures for MFIs to open bank accounts, as has been done in Guinea and Benin, and help launch MFIs, as a few banks in Cameroon have done. In Guinea, commercial banks even provide liquidity management services such as lines of credit to MFIs (Basu, Blavy, and Yulek, 2004). The National Association of MFIs can also provide training and other technical support to MFIs to improve operations accounts as overhead costs are high, and strengthen accounting practices.

\section{Strategy to Improve the Soundness of the Financial Sector}

\section{Improving Prudential Regulations}

\footnotetext{
${ }^{36}$ Based largely in Ghana, susu collectors, who exercise a form of microfinance, charge a small fee and provide an informal means for Ghanaians to securely save and access their own money and gain limited access to credit.
} 


\section{Banks}

\section{To better supervise banks, COBAC would need greater operational}

independence. An independent regulator would be free of political pressure and could make unbiased, prompt decisions. However, COBAC enforcement of regulation is inhibited because finance ministries throughout CEMAC retain the right to license banks. Hence, as a first step in strengthening the role of the regional supervisor, the ministry may consider releasing rights to issue and revoke bank licenses to COBAC.

117. COBAC also needs staff to undertake its regulatory mandate. As pointed out in the CEMAC FSSA (2006), there is an increasing gap between COBAC's missions and its resources. This understaffing limits the capacity of conducting timely on-site and off-site examinations. At the national level, only one staff member in the BEAC acts as a local correspondent of COBAC. The correspondent's role is to liaise with COBAC, provide it with data, and stay in contact with banks. Nevertheless, this liaison does not work well. Therefore, COBAC might hire more staff, and it might assess its correspondent's workload and assign more resources, if needed.

\section{Microfinance Institutions}

\section{COBAC will begin regulating MFIs in 2007 according to regional regulations} adopted in 2002. CEMAC classifies MFIs under a three-category system, and prudential regulations vary by category. There is still some confusion about the legal and reporting requirements that will govern COBAC supervision. Some MFI representatives and donors think that prudential ratios and other traditional regulatory mechanisms are too complicated and restrictive for MFIs. COBAC, with help from the National Association of MFIs, might test such ratios in Congo to see whether they can be realistically used for MFIs.

\section{Regional regulation will require cooperative networks to have enough capacity} to aggregate their members' balance sheets. Otherwise, data inaccuracies and dissemination delays will make it difficult for the regulator to identify, monitor, and control sectoral risks. The MUCODEC already has such capacity. COBAC and the National Association of MFIs might work with other cooperative networks to assess their capacity to consolidate their members' balance sheets and, if not, to give them the advice and resources they need to build such capacity. 


\section{Insurance and Pension Funds}

120. The insurance sector is regulated through the Inter-African Conference on Insurance Markets (CIMA). The Regional Insurance Control Commission licenses insurance companies and imposes penalties. Because commission members are appointed by national authorities, they may be subject to political pressures. Moreover, the National Director of Insurance can withhold licenses approved by the Regional Insurance Control Commission.

\section{As pointed in CEMAC FSSA, the division of responsibilities and labor between} the CIMA and the National Director of Insurance is not clear. The National Director of Insurance's participation in inspecting, following-up, and monitoring insurance companies is not clearly defined and is limited by its low institutional capacity. The authorities might clarify this and improve the institutional capacity. The National Director of Insurance might also ensure that insurance companies pay CIMA the mandated fees. Given that the stateowned insurance company is in critical financial condition, the National Director of Insurance might consider cooperating with CIMA as well as with international financial institutions to privatize the company.

\section{The pension funds' supervisor, the Ministry of Labor, should be empowered to} strengthen the finances of the two funds. CNSS and CREF are both having serious difficulties in meeting their obligations. CREF's problem is that its key contributors, the central government and public enterprises, are in arrears. There is no payment of contribution to the CNSS by private companies. Therefore, the supervisor might be given the right to demand the full amount of owed contributions. If immediate payment is not possible, the supervisors might work with contributors to reach agreements on a timetable to settle arrears.

\section{A range of appropriate regulatory and supervisory framework might be}

established to oversee pensions. The two pension funds should be audited by audit firms of international reputation. Moreover, the supervisor should assess the existence and effectiveness of regulatory framework (pension laws, governance structures, accounting and auditing rules and practices, disclosure, investment regulations, etc.) and the supervisory framework (approach to supervision, legal status and internal structure of the supervisory agency, regulatory and enforcement powers of supervisor, ability to carry out early interventions, and relationship with other supervisors. ${ }^{37}$ )

\footnotetext{
${ }^{37}$ The World Bank and International Monetary Fund, 2005.
} 


\section{Improving Risk Management}

124. Financial institutions are exposed to risks from different angles. A volatile macroeconomic situation (i.e., a high inflation rate) distorts the price of credit, impairs confidence in the financial sector, and thus hinders its development. Credit risk arises from uncertainty about whether a borrower can meet its obligations. Default on its obligations drives up NPLs and reduces asset quality. Interest rate risks can weaken financial institution balance sheets when interest rates move in an adverse direction. Exchange rate risks arise from mismatches in the currency composition of assets and liabilities. Liquidity risks arise when an investment cannot be bought or sold quickly enough to prevent or minimize a loss.

125. Though day-to-day risk management is the responsibility of financial institutions, the authorities can take supportive measures, and regulators can enforce risk regulations. Financial institutions manage risk by analyzing exposures to risk and determining how best to handle them. By providing macroeconomic stability, adequate infrastructure, and a sound legal system, the authorities can help financial institutions better handle their risk exposure. The regulators should enforce regulation to reduce the vulnerability.

\section{Exposure to Risk}

126. Credit risk is the main source of vulnerability (CEMAC FSSA 2006). The loan portfolio, and thus credit risk exposure, is highly concentrated in the forestry sector. A downturn in forestry revenue would severely strain banks. Moreover, the process of enforcing contracts and recovering losses is hampered by an inadequate legal system and lack of an updated property registry. Also, as mentioned before, Congolese financial institutions are exposed to macroeconomic risk mainly through the economic dominance of the oil sector.

\section{Congolese banks are somewhat exposed to interest rate risks. Loans are} overwhelmingly (80 percent) short term, and demand deposits account for 92.9 percent of total deposits. This short duration of deposits and loans reduces the interest rate risk, especially duration risk. Nevertheless, because most bank loans are at fixed rates, an increase in the short-term fund rate will affect the capital adequacy ratios of Congolese banks, as noted in the CEMAC FSSA (2006).

128. Congolese banks' exposure to exchange rate risk should be limited. Congo's currency, the CFA franc, is pegged to the euro and, through an Operations Account, the French treasury guarantees the unlimited convertibility of the CFA franc at a given rate. In principle, residents cannot hold foreign exchange accounts domestically, and the following surrender requirement applies: "export proceeds received in currencies other than Euros or 
those of other Operations Account countries must be surrendered within one month of collection. ${ }^{38 "}$ Nevertheless, banks have net long foreign currency positions, which expose them to risk. A CFA franc depreciation against the U.S. dollar would improve their capital adequacy ratios and vice versa.

129. Banks' exposure to liquidity risk is limited. As shown in the CEMAC FSSA (2006), a 25 percent withdrawal of all deposits or 50 percent reduction of public sector deposits has a modest effect, which is explained by a low loan deposit ratio (25.9 percent compared with the CEMAC average of 48.0 percent). Nevertheless, Congolese banks rely on a high share of government and public enterprises deposits, and a shock from the oil sector will affect the stability in the financial system.

\section{Handling Risk Exposure}

130. The government might cease borrowing from commercial banks. This would help them handle oil sector shocks. A policy of zero direct government borrowing from commercial banks would keep government fiscal solvency problems from being transmitted to the financial sector. Government borrowing from commercial banks may also crowd out private sector investment by stimulating higher interest rates. In Congo, though excess reserves offset the crowding-out effect, government borrowing nevertheless may have distorted the price of credit. Keeping all the government deposits in the Treasury Single Account (TSA) at the BEAC may also increase the transparency of fiscal management (see Chapter III).

\section{It is important for Congo to diversify the economy and improve its business}

environment. Though it takes time to diversify the economy, efforts in this direction might broaden the client base for financial institutions, enabling them to diversify and stabilize their loan and deposit portfolios and therefore reduce credit and liquidity risk.

\section{A liquid interbank market helps banks to manage liquidity risk. A well-}

functioning interbank market could effectively channel liquidity from banks with surplus liquidity to those in need, allowing banks to trade liquidity to manage liquidity and interest rate risk. Because the current interbank market is shallow (which is partly explained by the excess reserves), the national BEAC should work with the BEAC headquarter to overcome obstacles to market development. As only four banks dominate the financial sector in Congo, COBAC might analyze whether allowing MFIs, at least the MUCODEC network, to participate in the interbank market could increase liquidity.

\footnotetext{
${ }^{38}$ See IMF (2006).
} 


\section{E. Conclusion}

\section{The financial sector in Congo is still underdeveloped, and financial}

intermediation is low. Households and SMEs have limited access to financial services. The financial sector is fragile and susceptible to risk. These features keep the financial sector from playing a greater role in promoting growth and reducing poverty.

134. This paper proposed a comprehensive financial sector strategy. The strategy calls for authorities to (i) widen access and lower the cost of financial services by facilitating the intermediation of new financial instruments; (ii) increase competition through a more open licensing policy and by encouraging regional financial integration in the CEMAC; (iii) reduce credit risk by strengthening loan recovery procedures and widening the types of collateral; (iv) improve the health of the nonbank financial sector (particularly insurance companies and pension funds); and (v) require the sector to follow sound regulatory and prudential practices. Such measures, if implemented, could contribute to financial sector development, thus increasing financial intermediation. This, in turn, could contribute to higher sustainable growth. 


\section{References}

African Development Fund, 2006, Republic of Congo, Project in Support of the SocioEconomic Reintegration of Disadvantaged Groups, Appraisal Report. (Côte d'Ivoire: African Development Fund).

Basu, Anupam, Rodolphe Blavy, and Murat Yulek, 2004, "Microfinance in Africa: Experience and Lessons from Selected African Countries," IMF Working Paper 04/174 (Washington: International Monetary Fund).

Banque des Etats d'Afrique Centrale (BEAC), 2004, "Bulletin du Marché Monétaire" No. 125, Novembre 2004. (Yaoundé : BEAC)

Berthelemy, Jean-Claude, and Aristomene Varoudakis, 1996, "Economic Growth, Convergence Clubs, and the Role of Financial Development," Oxford Economic Papers, Vol. 48, pp. 300-28.

Burgess, Robin, and Rohini Pande, 2004, "Do Rural Banks Matter? Evidence from the Indian Social Banking Experiment," CEPR Discussion Papers 4211.

Commission Bancaire de l'Afrique Centrale (COBAC), "Rapport d'Activités 2002," (Yaoundé : COBAC)

Commission Bancaire de l'Afrique Centrale (COBAC), "Rapport d'Activités 2003," (Yaoundé : COBAC)

Christensen, Jakob, 2004, "Domestic Debt Markets in Sub-Saharan Africa," IMF Working Paper 04/46 (Washington: International Monetary Fund).

Department for International Development, the United Kingdom Government, 2004, "The Importance of Financial Sector Development for Growth and Poverty Reduction," (London: DFID)

International Monetary Fund, 2001, Senegal, Financial System Stability Assessment, IMF Country Report No. 01/189 (Washington: International Monetary Fund).

—, 2002, Gabon, Financial System Stability Assessment, IMF Country Report 02/98 (Washington: International Monetary Fund).

—, 2003, Morocco, Financial System Stability Assessment, IMF Country Report 03/212 (Washington: International Monetary Fund).

—, 2003, Mauritius, Financial System Stability Assessment, IMF Country Report 03/321 (Washington: International Monetary Fund). 
_, 2003, Ghana, Financial System Stability Assessment update, IMF Country Report 03/396 (Washington: International Monetary Fund).

- 2005 , Central African Economic and Monetary Community---Recent economic Developments and Regional Policy Issues, IMF Country Report 05/403 (Washington: International Monetary Fund).

— , 2006, Sub-Saharan Africa Regional Economic Outlook, (Washington: International Monetary Fund).

- 2006, Central African Economic and Monetary Community, Financial System Stability Assessment, IMF Country Report 06/321 (Washington: International Monetary Fund).

Levin, Ross, 1997, "Financial Development and Economic Growth," Journal of Economic Literature, Vol. 35, pp. 688-726.

Sacerdoti, Emilio, 2005, "Access to Bank Credit in Sub-Saharan Africa: Key Issues and Reform Strategies," IMF Working Paper 05/166 (Washington: International Monetary Fund).

Saxegaard, Magnus, 2006, "Excess Liquidity and Effectiveness of Monetary Policy: Evidence from Sub-Saharan Africa," IMF Working Paper 06/115 (Washington: International Monetary Fund).

Veyrune, Roman, 2006, "Fixed Exchange Rate and Autonomy of Monetary Policy: the Franc Zone Case," Unpublished.

The World Bank and International Monetary Fund, 2005, Financial Sector Assessment, a Handbook (Washington: International Monetary Fund). 


\section{IMPROVING The TRADE REgIME FOR GROWTH ${ }^{42}$}

\section{A. Introduction}

135. External trade is vital to Congo's economy. The Congolese economy relies heavily on oil exports, which make up about 90 percent of total exports, and on imported food, machinery, transportation equipment, and medicines. The ratio of merchandise trade-to-GDP has been fairly steady at about 137 percent (Figure VI.1). Despite being highly dependent on trade, Congo's numerous import and export barriers strain its capacity to rebuild after years of civil war, and imperil its ability to advance toward the Millennium Development Goals (MDGs).

Figure VI.1. Republic of Congo: Openness Indicator ${ }^{1}, 2001-06$

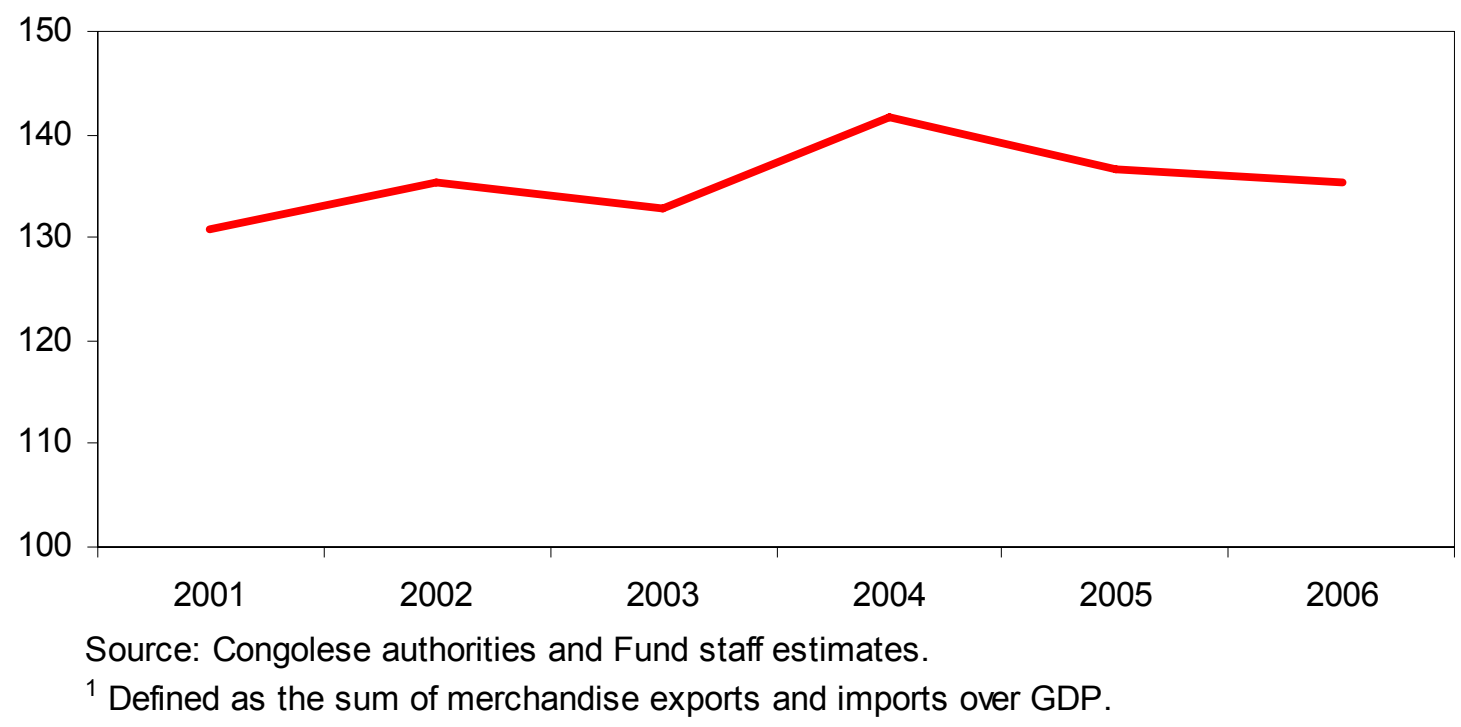

136. Increased import volumes, despite high import taxes, do not translate into higher customs revenues in Congo. As a member of the Economic and Monetary Community of Central Africa (CEMAC), ${ }^{43}$ Congo's tariff scheme is formally guided by CEMAC's trade policy framework, which applies higher and more dispersed tariff rates than other comparable regional arrangements. These higher rates, however, do not result in higher fiscal revenues, because Congo recently has greatly increased its tariff exemptions. Congo

\footnotetext{
${ }^{42}$ Prepared by Maria Oliva.

${ }^{43}$ CEMAC succeeded the Customs and Economic Union of Central Africa in 1994. Under CEMAC, member countries agreed to liberalize trade and establish a single market. See Oliva [2006] for a detailed analysis of CEMAC's trade policy scheme and trade reform agenda.
} 
also applies a number of quantitative and qualitative trade barriers, hindering its development strategy. Indeed, without trade reforms that make the regime less complex and more transparent and predictable, Congo could falter in its efforts to develop its non-oil sector and diversify the country's export base.

\section{B. The CEMAC Zone: An Overview}

\section{Congo's trade policy is, at least formally, defined by CEMAC and other} international commitments. Congo is a member of CEMAC and (since 1995) the World Trade Organization. Its tariff regime is defined by the CEMAC customs code approved in 1994, whose Common External Tariff (CET) ranges from 5 to 30 percent. Congo also is a member of the Economic Community of Central African States (ECCAS) and is eligible for the U.S. African Growth and Opportunity Act (AGOA) (since 2000), the Economic Partnership Agreement (EPA) with the European Union (EU), and the EU's Generalized System of Preferences (GSP) program. Congo recently signed bilateral trade agreements with Brazil, Cuba, China, South Korea, Turkey, South Africa, and Vietnam.

\section{Active involvement by CEMAC countries in overlapping regional trade} arrangements has failed to deepen economic integration. Like other CEMAC countries, Congo has increasingly participated in different, often overlapping regional arrangements (Figure VI.2). Congolese trade vis-à-vis other CEMAC countries, and more broadly intraregional trade in the CEMAC region, remains sluggish. The reasons for this point to a number of distinctive structural traits CEMAC economies share: high dependence on oil and forestry, lack of economic complementarities, high tariff and nontariff barriers, and de facto labor and capital minimal factor mobility (Oliva 2006, Zafar and Kubota 2003). These traits, however, are endogenously driven by the policies in place.

139. There are strong arguments for reforming CEMAC trade policies. The CEMAC trade policy framework is more restrictive than that of other comparable groups. Although back in 1994 the CEMAC customs union was a key step toward integrating Central Africa and liberalizing the region's trade policies, today its trade policies are outdated and overly restrictive: 
Figure VI.2: Africa’s Spaghetti Bowl

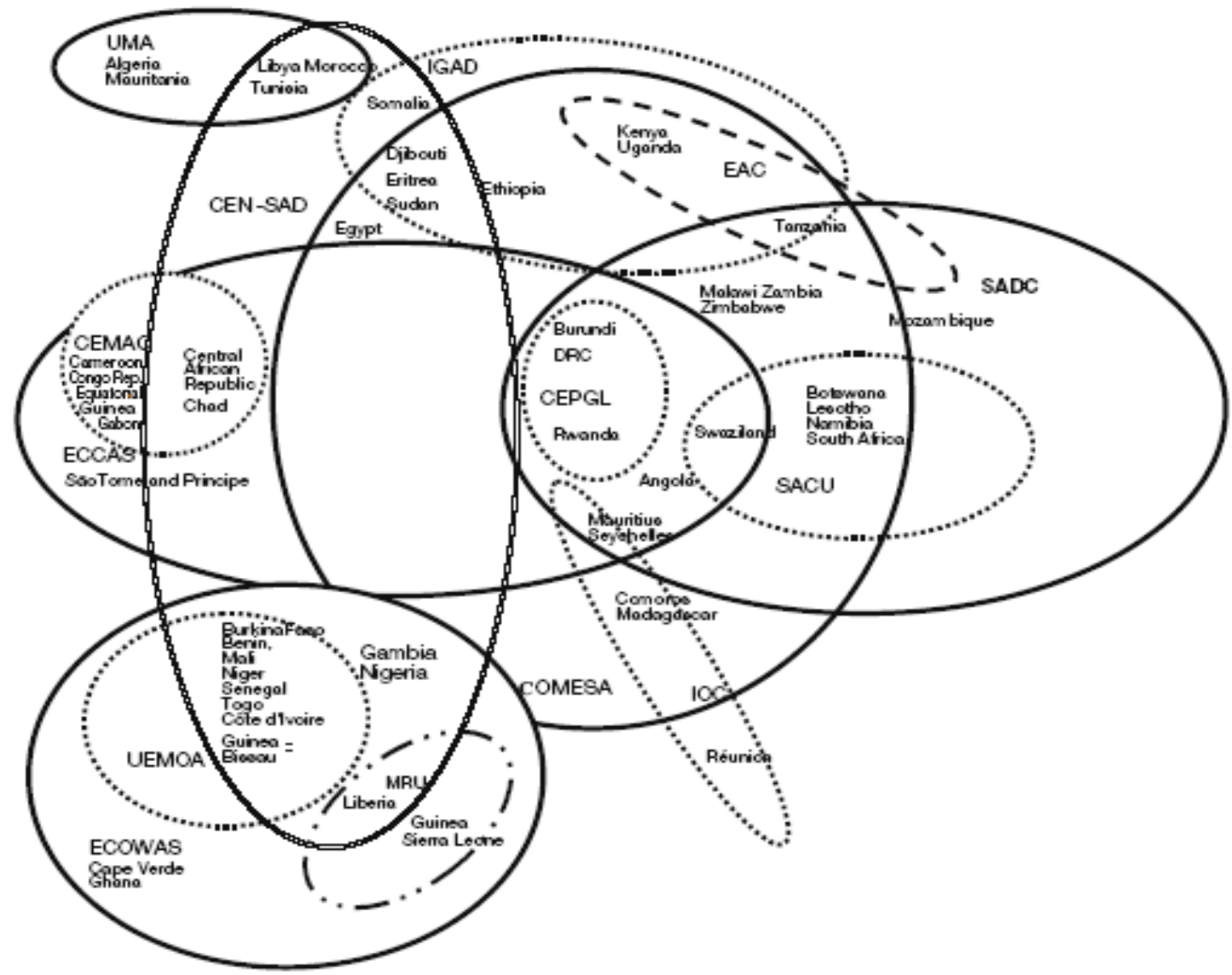

Source: UNECA (2006).

Tariff rates are too high (Table VI.1). CEMAC's average MFN rate in 2005 was 19.1 percent, at least 50 percent higher than in comparable customs unions, such as the West African and Monetary Union (WAEMU) and the East African Customs Union. The CEMAC's 1994 tariff regime includes many internal taxes and duties set by each member country within a predetermined range, including (i) a statistical tax, with a rate on imports that cannot exceed 2 percent; (ii) an excise tax, with a basic rate of $0-25$ percent of the customs value; and (iii) the value-added tax (VAT), also applied to domestic products, with a basic rate of 15-18 percent. The statistical tax is meant to cover the cost of computerizing customs processes, automating data collection, and administrative costs. However, CEMAC members apply other taxes, such as an automation fee and a municipality tax, that may be in violation of the CEMAC Agreement. 
Table VI.1. The Common External Tariff by Regional Agreement

\begin{tabular}{lrrr}
\hline Custom Union & $\begin{array}{c}\text { Number of Tarif } \\
\text { Lines }\end{array}$ & Average MFN Rate Standard Deviation \\
\hline CEMAC & 6,172 & 19.1 & 9.6 \\
WAEMU & 5,646 & 12.1 & 6.8 \\
East African Customs Union & 5,422 & 12.9 & 11.9 \\
SACU & 6,450 & 8.0 & 10.8 \\
\hline
\end{tabular}

Source: TRAINS (2006) and Fund staff estimates.

The tariff structure has significant dispersion, as measured by the MFN standard deviation. The standard deviation of CEMAC's unweighted MFN average rate in 2005 was 9.6 percent, compared with 6.8 percent for WAEMU countries and 11.9 percent for the East African Customs Union and 10.8 percent for the Southern African Customs Union (SACU). When higher average MFN rates are also taken into account the CEMAC region ranks as the most restrictive (Table VI.2).

Nontariff barriers abound. The number of requirements set by CEMAC countries far exceeds that in other sub-Saharan African countries (Table VI.3). The World Bank's 2007 Doing Business survey reports that exports in CEMAC countries, on average, cost about 20 percent more than in other WAEMU countries. Excluding Cameroon (whose average cost of exports is just $\$ 524$ per container), average CEMAC export costs are about $\$ 1,700$, more than for sub-Saharan African economies. Furthermore, the time required to import and export goods tends to be higher in the CEMAC zone than in the WAEMU zone. Greater export diversification thus hinges on improving the region's business climate.

Regional trade flows are mostly governed by North-South relations. CEMAC's intraregional trade is an estimated 3.0 percent of total trade, far below WAEMU's share of about 9.4 percent (Masson and Pattillo 2005). Trade between CEMAC and WAEMU is almost nonexistent. Meanwhile, trade between CEMAC and France is more than 10 times CEMAC's intraregional trade. Nontransparent and costly procedures have hampered trade flows, contributed to inefficient resource allocation, and hurt economic diversification, leaving many CEMAC countries highly dependent on trading a few natural resources with the European Union, the United States, and China. 
Table VI.3. The Use of Non Tariff Barriers ${ }^{1}$

\begin{tabular}{lrrr}
\hline Trading Across Borders & $\begin{array}{c}\text { CEMAC } \\
\text { Countries }\end{array}$ & $\begin{array}{c}\text { WAEMU } \\
\text { Countries }\end{array}$ & $\begin{array}{c}\text { Sub-Saharan } \\
\text { Economies }\end{array}$ \\
\hline Documents for Export (number) & 8 & 8 & 8 \\
Time for Export (days) & 51 & 41 & 40 \\
Cost to Export (USD per container) & 1,924 & 1182 & 1,561 \\
Documents for Import (number) & 14 & 14 & 12 \\
Time for Import (days) & 62 & 54 & 52 \\
Cost to Import (USD per container) & 2,313 & 1837 & 1,947 \\
\hline Source: World Bank (2006) and Fund staff estimates. & & \\
${ }^{1}$ Averages. & & &
\end{tabular}

\section{Congo's Trade Regime: Theory and Practice}

140. Little information is available on Congo's trade policies. The most recent data on trade flows are from 1995 (see COMTRADE and TRAINs databases, published by UNCTAD). To date, trade flow data rely on mirror statistics from trading partner countries. Exceptions include the World Trade Organization (WTO) trade policy report of September 2006 and data on United States-Congo trade exchanges under the African Growth and Opportunity Act (AGOA). The WTO report is the first on Congolese trade policies since Congo jointed the WTO in 1995.

\section{Congo's trade regime is less transparent and more restrictive than that defined} by the CEMAC. Duties and taxes not envisaged in the CEMAC framework that are systematically applied to Congolese imports and exports include an automation fee, municipalization tax, routing fee, and a wood export tax (Table VI.4). Other quantitative and qualitative nontariff barriers (e.g., price fixing, quotas, licensing, fraud, lack of information, and poor transportation) also apply, putting economic development goals at risk: 
Table VI.4. Congolese Tariff Code. Summary of Main Instruments

\begin{tabular}{|c|c|c|c|}
\hline \multicolumn{2}{|c|}{ IMPORT REGIME } & \multicolumn{2}{|c|}{ EXPORT REGIME } \\
\hline Measure & Applied rate & Measure & Applied rate \\
\hline Applicable to Imports & & Export duty & $2 \%$ to $20 \%$ \\
\hline (i) CEMAC's Tariff Code & & Royalties on Wood & $8 \%$ \\
\hline Common External Tariff & $\begin{array}{c}0 \%, 5 \%, 10 \%, 20 \%, \\
30 \%\end{array}$ & Routing fond & $\begin{array}{l}75 \text { franc/m3: Congolese wood; } \\
100 \text { franc/m3: CEMAC wood; } \\
250 \text { franc/m3: Third countries' wood }\end{array}$ \\
\hline Statistical Tax & $0.2 \%$ & Royalty on diamonds & $2 \%$ \\
\hline (ii) Regional Taxes & & Access rights to exit & $2 \%$ \\
\hline Regional Integration tax $(\mathrm{TCl})$ & $1 \%$ & & \\
\hline Tax CEEAC $(\mathrm{CCl})$ & $0.4 \%$ & & \\
\hline \multicolumn{4}{|l|}{ OHADA Levy } \\
\hline \multicolumn{4}{|l|}{ (iii) Others } \\
\hline Automation fee & $1.0 \%$ & & \\
\hline Municipality Tax (MT) & $20.0 \%$ & & \\
\hline Advance payment on income taxes & $5 \%$ & & \\
\hline \multicolumn{4}{|c|}{$\begin{array}{l}\text { Tax on imports of wood and derivatives } \\
\text { (except for those to supply local } \\
\text { industries) }\end{array}$} \\
\hline \multicolumn{4}{|c|}{ Applicable to Domestic Production and Imports } \\
\hline Value Added Tax & $18.0 \%$ & & \\
\hline CEMAC's Value added tax & $18.0 \%$ & & \\
\hline Excisse taxes & $24 \%$ & & \\
\hline
\end{tabular}

Source: Congolese authorities, WTO (2006) and Fund staff estimates.

Congo's average tariff exceeds the CEMAC rate. Congo's simple average applied MFN rate is 18.7 percent; the rate rises to 22 percent after accounting for other duties and taxes applied to imports. Such tariffs include, for example, an automation fee of 2 percent (since 2003) originally included in the statistical tax; the municipality tax on imports from the Democratic Republic of Congo (DRC); the OHADA levy, and integrationrelated duties on imports originating in non-CEMAC countries. Congo also imposes a levy of 5 percent of import value, which counts as an advance payment toward income taxes, and a maritime transportation fee to SOCOTRAM ${ }^{39}$ on all imports and exports shipped to and from Congo. Congo's commitments under the WTO bound these other taxes and duties to zero (WTO 2006, p. viii).

Quantitative nontariff barriers are prominent in the Congolese trade regime. Nontariff barriers include price controls, licensing procedures, quotas, and monopolistic measures (Table VI.5). Such measures often conflict with progrowth policies, as they put upward pressure on basic product prices and can contribute to shortages. Two cases in point are sugar and wheat flow, both of which are in short supply but are subject to protection measures as licensing procedures, domestic monopolies (the companies SARIS and MINOCO, respectively, hold a monopoly on the production of sugar and wheat flour and dictate the policy on licensing for imports), administrative prices, and quotas. Along with import protection, SARIS benefits from export subsidies.

\footnotetext{
${ }^{39}$ SOCOTRAM is a state-own company that holds the national traffic rights for 40 percent of operations. Although, Congo officially abolished traffic sharing back in 2000, traffic sharing continues in practice.
} 
Table VI.5. Congo's Use of Non tariff Barriers

\begin{tabular}{ll}
\hline Instruments & Products \\
\hline Import Licensing ${ }^{1}$ & Staple food, forest products, petroleum products. \\
Import/Export Licensing & Diamonds (outside Kimberley Process) \\
Monopoly & $\begin{array}{l}\text { SARIS, sugar } \\
\text { MINOCO, wheat flour }\end{array}$ \\
Quotas & $\begin{array}{l}\text { Sugar and wheat flour } \\
\text { Processed wood exports }\end{array}$ \\
Price Controls & $\begin{array}{l}\text { Petroleum, water, electricity } \\
\text { Postal and telecom services } \\
\text { Staple foods }\end{array}$ \\
& $\begin{array}{l}\text { Enterprises in the petroleum sector } \\
\text { Commercial activities related with collection, } \\
\text { storage, distribution of locally manufactured } \\
\text { products } \\
\text { Tax concessions }\end{array}$ \\
\hline
\end{tabular}

Source: WTO (2006)

${ }^{1}$ The import licensing procedure is being revised.

$>$ Compared with other CEMAC countries, it takes less time to export and import goods to Congo, though the time required is still fairly significant (Table VI.6). The average costs associated with importing and exporting goods to Congo, however, far exceeds the average in CEMAC, WAEMU, and other sub-Saharan economies.

$>$ Qualitative nontariff barriers may further distort the picture. Factors that render the current regime unpredictable and noncompetitive include lack of information and uncertainty related to imperfectly implemented preferential arrangements, poor and inefficient customs administration, costly and cumbersome transit procedures, double taxation, the discretionary application of exemptions, and Congo's weak and costly infrastructure. 
Table VI.6. The Use of Non Tariff Barriers ${ }^{1}$

\begin{tabular}{lrrr}
\hline Trading Across Borders & $\begin{array}{c}\text { CEMAC } \\
\text { Countries }\end{array}$ & $\begin{array}{c}\text { WAEMU } \\
\text { Countries }\end{array}$ & $\begin{array}{c}\text { Sub-Saharan } \\
\text { Economies }\end{array}$ \\
\hline Documents for Export (number) & 8 & 8 & 8 \\
Time for Export (days) & 51 & 41 & 40 \\
Cost to Export (USD per container) & 1,924 & 1,182 & 1,561 \\
Documents for Import (number) & 14 & 14 & 12 \\
Time for Import (days) & 62 & 54 & 52 \\
Cost to Import (USD per container) & 2,313 & 1,837 & 1,947 \\
& & & \\
\hline
\end{tabular}

Source: World Bank (2006) and Fund staff estimates.

${ }^{1}$ Averages.

\section{Trade barriers are hurting Congo's development efforts and its external}

competitiveness. As a first step, authorities approved in February 2007 a decree liberalizing the price and importation of cement. Besides price controls and a cumbersome import regime, imported cement and food staples must go through heavy red tape and withstand a poor and costly inland transportation network (Box VI.1). Inconsistencies between the current trade regime and a progrowth strategy result in artificially high import costs on key inputs (e.g. cement, manufacture of electrical appliances, manufacture of rubber products); other duties, taxes, and surcharges on exports; departures from the WTO transaction-based import valuation methods; administered prices on 14 products in short supply; lack of storage capacity, which promotes price volatility; and lack of transparency.

\section{A Strategy to Simplify Congo's Trade Regime}

143. Simplifying Congo's applied tariff and para-tariff schemes and making its trade regime more transparent and predictable would facilitate trade (Appendix 1). The following measures would simplify Congo's applied trade policy scheme:

$>$ Consolidate trade taxes and eliminate para-tariff measures (e.g., the automation fee, transportation fees, and the municipality fee) that remit little revenue to Congo's treasury and may conflict with the country's international commitments. Such consolidation would enhance trade and reduce the scope for discretionary practices.

Limit the uncertainty faced by importers and exporters, enhance transparency, and make Congo's business environment more efficient. Corrective measures include publishing:

(i) the full list of tariff lines subject to para-tariff measures; (ii) all applicable quantitative nontariff measures (e.g., licensing requirements, prohibitions, and quotas among others); (iii) exemptions to the VAT and excises; and (iv) earmarked subventions to exports. 


\section{Box VI.1: The Case of Cement}

Formally, under the 2001 Congolese customs code, cement is subject to the following taxes:

the common external tariff, which is around 30 percent, on average

$>$ the automation fee of 1 percent of cement's customs value

$>$ the VAT with a rate of 18 percent

$>$ the CEMAC regional tax of 1 percent of the customs value and a 0.4 percent of customs value financing the CEEAC

a transportation fee (redevance fluviale) of CFAF 650 per ton on imports from the Democratic Republic of Congo

$>$ the price of cement sold in Congo is an administered price fixed by the government. And, the reference value used to calculate the customs value was increased from CFAF 20,00 per ton to CFAF 40,00 in 2006.

Such high level of trade protection creates substantial bottlenecks for construction activity.

$>$ Ease staple-food shortages and reduce capacity constraints by eliminating quantitative and qualitative trade barriers that inflate prices on such products as sugar and wheat flour. Recommended measures include: (i) easing import restrictions (e.g., eliminating the SARIS and MINOCO's monopolies and simplifying licensing procedures); (ii) eliminating subsidies and tax concessions favoring domestic monopolies; (iii) phasing out administrative prices; and (iv) strengthening customs administration.

\section{Congo mostly trades with large countries and, even when eligible, often fails to} receive preferential treatment. Congo mostly trades with the United States (mostly through oil exports), the European Union, and China. Congo tends to import textiles and footwear, machinery and transportation equipment, and electronic products. Congo reaps little benefit from preferential arrangements, despite being a beneficiary of several preferential programs (i.e., AGOA with the United States; the Africa, Caribbean, and Pacific-European Union Economic Partnership Agreement, which is now being renegotiated; and the generalized system of preferences granted to least developed economies). According to the WTO, no product exported to the United States has yet benefited from the AGOA program. Analysts often attribute the agreement's limited use to stringent rules of origin and standards and to trade barriers and economic constraints in Congo, including high production costs, chaotic and unregulated cross-border activity, and non transparent goods transshipment procedures (USAID 2004). 


\section{Congo's Trade Policy, Customs Revenues and Exemptions}

\section{The CET and VAT account for about $\mathbf{4 4}$ and 35 percent of customs revenues,} respectively. After the CET and VAT taxes, royalties on wood exports and the automation fee generate the most revenue. Tax instruments that have gained prominence since 2001 include the automation fee, export duties and royalties on wood, the Chamber of Commerce and Industry (CCI) fee, and pre-inspection fees. Together, these instruments make up 20-25 percent of total revenues from trade taxation. A number of instruments do not contribute to tariff collection (e.g., export duty, the road fund, the municipality tax) and simply make the regime cumbersome and less transparent.

\section{Congo's high tariff and tax rates have failed to boost trade-related revenue} collection. As a percentage of GDP, Congolese revenue from taxation of international trade fell to about 3.6 percent of total trade in 2003 and 2004, from 4.7 percent in 2001 (Table VI.7). Despite high tariff rates and a jump in imports, import duties also declined in 2002-03 and 2004-05, raising questions about the effectiveness of customs administration (the computerized ASYCUDA is expected to be fully operational by December 2006), the number of exemptions in recent years, and difficulties in applying the WTO-agreed transaction-based customs valuation system.

Table VI.7. Republic of Congo: Revenue from Taxation of International Trade

\begin{tabular}{lrrrr}
\hline & 2001 & 2004 & $2005^{1}$ & $2006^{1}$ \\
\hline In millions of CFAF & 97,061 & 83,058 & 72,792 & 92,916 \\
In percent of nominal non-oil GDP & 4.7 & 3.6 & 2.6 & 2.2 \\
In percent of nominal GDP & 10.9 & 7.6 & 5.8 & 6.9 \\
In percent of Fiscal Revenue & 15.4 & 11.1 & 6.7 & 4.4 \\
In percent of trade of goods and non-factor services & 2.4 & 1.6 & 1.6 & 1.4 \\
\hline
\end{tabular}

Source: WTO (2006) and Fund staff estimates.

${ }^{1}$ Preliminary estimates based on first semester data.

147. Exemptions have more than doubled in recent years, hurting revenue collection (Table VI.8). Overall first-half of 2006 exemptions were comparable to the year-end 2005 level, which was already more than double that at year-end 2004. Overall exemptions in 2005 were CFAF 109 billion ( 3.5 percent of GDP and about 9 percent of non-oil GDP), more than twice earlier levels. Exemptions in 2004 were 2.3 percent of GDP. Exemptions in 2005 were especially heavy for oil products (which make up about 84 percent of the total), for wheat flour imports by MINOCO, and for exceptional reasons by the presidency. In the first half of 2006, most exemptions were for the oil sector and imports under the statutory classification. Officially, Congo exempts products in transit that have been granted temporary admission and products placed under customs warehousing. In practice, though, a 
number of other products, such as those related to municipalization (see the pro-investment rubric in Table 7), also are exempted, suggesting that there is a need to strengthen the preshipment regime for import shipments valued at CFAF 3 million or more and to end discretionary practices in granting exemptions.

Table VI.8. Republic of Congo: Trade Exemptions ${ }^{1}$

\begin{tabular}{lrrrr}
\hline Exemptions & 2001 & 2004 & 2005 & 2006 \\
\hline Total (Millions of CFAF) & 55,219 & 52,086 & 108,957 & 107,298 \\
Share of exemption (in percent): & 100 & 100 & 100 & 100 \\
Petroleum sector & 65 & 69 & 84 & 85 \\
Statutory & 7 & 13 & 5 & 9 \\
Investment promotion & 15 & 13 & 7 & 4 \\
Exceptional measures & 12 & 5 & 4 & 2 \\
\hline
\end{tabular}

Source: WTO (2006), Congolese authorities and Fund staff estimates.

${ }^{1} 2006$ data refers up to June 2006.

148. Eliminating all exemptions could greatly impact revenue collection (Table VI.9). Exemptions in 2005 account for an estimated 60 percent and in 2006 an estimated 54 percent of potential trade-related fiscal revenue, meaning that trade revenues are expected to be less than the amount spent on tax exemptions.

Table VI.9. Republic of Congo: Revenue from Taxation of International Trade

\begin{tabular}{lrrrr}
\hline & 2001 & 2004 & $2005^{1}$ & $2006^{1}$ \\
\hline & & & & \\
Total potential revenue (Millions of CFAF) & 152,280 & 135,144 & 181,749 & 200,214 \\
& & & & \\
Share of potential revenue (in percent): & 100.0 & 100.0 & 100.0 & 100.0 \\
Actual trade revenue & 63.7 & 61.5 & 40.1 & 46.4 \\
Exemptions & 36.3 & 38.5 & 59.9 & 53.6 \\
\hline
\end{tabular}

Source: WTO (2006) and Fund staff estimates.

${ }^{1}$ Preliminary estimates based on first semester data.

149. To strengthen customs duty collection, authorities must takes steps to consolidate and harmonize tax measures, rationalize exemptions, improve preshipment inspections, and strengthen customs administration (Table VI.10). Such measures would lessen external trade distortions and reduce trade inefficiencies. 


\section{E. Conclusions}

150. Economists widely agree that more open trade supports growth. Open trade can also have positive spillover effects on other aspects of policy reform. ${ }^{40}$ For Congo, such effects may be especially relevant given the economy's dependence on exports and imports and its struggle to overcome capacity constraints after years of civil war.

\section{Congo's coastal city Point-Noire could become the transit center and main} distribution port of Central Africa. Poor inland transportation, however, limits city access and is a major stumbling block to increasing economic activity there.

\section{With oil production expected to decline, diversifying Congo's trade structure is} essential to its economic vitality. Enhancing the business environment, promoting entrepreneurship, and removing supply-side barriers would help promote diversification. Reviewing the economic structure to identify potential new growth sectors with increasing world demand, as under the Integrated Framework Initiative, ${ }^{41}$ could help the authorities take such steps. The Diagnostic Trade Integration Study (DTIS) has been very useful in identifying potential growth sectors and in understanding trade bottlenecks.

\section{In sum, the authorities are encouraged to take the following measures to enhance Congo's trade performance:}

$>\quad$ Simplify applied tariff and para-tariff schemes by consolidating trade taxes and eliminating para-tariff measures (e.g., the automation fee, transportation fees, and OHADA levy) that may violate the country's international commitments and yield little revenue.

$>\quad$ Increase transparency and predictability to enhance trade volume and limit discretionary practices and corruption. Corrective measures could include the publication of (i) the full list of tariff lines subject to para-tariff measures as well as VAT and excises exemptions; and (ii) all applicable quantitative nontariff measures (e.g., licensing requirements, prohibitions, and quotas).

$>\quad$ Ease quantitative and qualitative nontariff barriers. Key measures could include eliminating the SARIS and MINOCO monopolies and simplifying licensing procedures; eliminating subsidies and tax concessions favoring domestic monopolies; phasing out administrative prices; and strengthening customs administration. Measures that would reinforce customs could include modernizing its operations, improving the training of customs officials, increasing anticorruption resources, and

\footnotetext{
${ }^{40}$ See Berg and Krueger (2003) for a survey of the literature on the links between trade and growth.

${ }^{41}$ See http://www.integratedframework.org for further details.
} 
extending customs operations at the border. Improving inland transportation and easing measures that limit the mobility of goods and services would also help strengthen regional trade.

Work at the regional level to reduce CEMAC's official external tariffs and other import barriers on extraregional goods as well as to consolidate all integrationrelated import taxes. The CEMAC framework, which is the basis of Congo's trade regime, is outdated and overly restrictive. The existing WAEMU CET has a maximum rate of 20 percent; the CEMAC's maximum is 30 percent. CEMAC code's structure also has mixed escalation patterns.

Rationalize sub-Saharan Africa's "spaghetti bowl” of regional arrangements to minimize overlapping membership costs and reconcile complex rules of origin. To keep from making the system even more cumbersome and unpredictable, and to limit the costs of regional arrangements, the authorities should (i) participate in regional integration projects that do not penalize outsiders; and (ii) negotiate clear, transparent, and liberal rules of origin. The main goal of preferential arrangements is to boost trade and reduce trade-related costs. Recommended measures to ease exchange costs at the regional level include enhancing customs operations, harmonizing product standards, and rationalizing "other duties and charges" (other than the customs tariffs) that apply exclusively to imports (e.g., automation fees, customs fees, and surcharges).

Enhance cooperation with the CEMAC Secretariat and facilitate surveillance (see Martijn and Tsangarides 2006). Owing to lack of data reporting, Congo's most recent trade flow statistics are from 1995. Timely data collection-both on trade flows and on country-specific regulations and practices - is essential for the CEMAC Secretariat to be effective. The staff urges the authorities to keep the CEMAC Secretariat well informed about trade data and policy implementation. 
Table VI.10. Summary of Recommendations

\begin{tabular}{|c|c|}
\hline Problems & Recommendations \\
\hline $\begin{array}{l}\text { Lack of transparency of the } \\
\text { currently applied trade policy } \\
\text { regime }\end{array}$ & $\begin{array}{l}\text { a) Publication on the internet of: } \\
\text { (i) the full list of tariff lines subject to para-tariff measures, } \\
\text { import licensing requirements, quotas, monopoly, price } \\
\text { controls, tax concessions, and prohibitions, as well as those } \\
\text { subject to exemptions and special excises. The list should } \\
\text { also indicate the rates applicable to each product line. } \\
\text { (ii) all applicable laws and regulations relating to tariff, VAT } \\
\text { and para-tariff exemptions. } \\
\text { (iii) all applicable laws and regulations relating to } \\
\text { preshipment inspection and exemptions to it. } \\
\text { (iv) developments under the CEEAC and implications for } \\
\text { Congo's trade policy } \\
\text { (v) bilateral agreements (including framework trade } \\
\text { facilitation arrangements) signed by Congo and implications } \\
\text { in terms of Congo's trade policy } \\
\text { b) Harmonization of para-tariff measures (customs fees, } \\
\text { surcharges and others) } \\
\text { c) Rationalization of exemptions: oil-related, statutory, pro- } \\
\text { investment and exceptional measures }\end{array}$ \\
\hline $\begin{array}{l}\text { High barriers to trade against } \\
\text { imports from non-regional } \\
\text { partners }\end{array}$ & $\begin{array}{l}\text { a) Removal of automatization and transportation fees } \\
\text { b) Application of transaction-based valuation method } \\
\text { c) Liberalization of the sugar and wheat flour markets } \\
\text { d) Tariffication of quotas on sugar and flour wheat imports, and of } \\
\text { wood exports } \\
\text { e) Simplification of license registration procedures }\end{array}$ \\
\hline Price distortion & $\begin{array}{l}\text { a) Encourage competition in the sugar and wheat flour markets } \\
\text { to reduce market prices } \\
\text { b) Removal of price controls on sugar, wheat flour, cement and } \\
\text { staple foods }\end{array}$ \\
\hline
\end{tabular}


Table VI.10. Summary of Recommendations (Concluded)

\begin{tabular}{|c|c|}
\hline Problems & Recommendations \\
\hline $\begin{array}{l}\text { Rationalizing the "Spaghetti } \\
\text { Bowl" }\end{array}$ & $\begin{array}{l}\text { a) Publication of rules of origin applicable under different } \\
\text { agreements } \\
\text { b) Publication of all applicable laws and regulations relating to } \\
\text { imports from regional/bilateral agreements' member countries }\end{array}$ \\
\hline $\begin{array}{l}\text { Supply-side constraints and } \\
\text { high costs to trade due to } \\
\text { market access imperfections }\end{array}$ & $\begin{array}{l}\text { a) Publication of a customs law clarifying responsibilities and } \\
\text { simplifying tasks } \\
\text { b) Post clearance audit checking for the efficiency of customs } \\
\text { clearance systems, revenue accounting, granting of exemptions, } \\
\text { revenue collection and data collection }\end{array}$ \\
\hline Lack of statistics on trade & a) Publication of trade flows data from 1995 onwards. \\
\hline $\begin{array}{l}\text { Need to define a strategy to } \\
\text { diversify the economy }\end{array}$ & $\begin{array}{l}\text { a) Diagnostic study of Congo's export potential and of barriers to } \\
\text { trade in the non-oil sector. The study should provide sectoral } \\
\text { analysis, and include action matrices with an action plan and a } \\
\text { reform timetable. This study could draw on those conducted } \\
\text { under the Integrated Framework Initiative }{ }^{1 /}\end{array}$ \\
\hline
\end{tabular}




\section{References}

Berg, A., and A. Krueger, 2003, “Trade, Growth, and Poverty: A Selective Survey,” IMF Working Paper 03/30, (Washington: International Monetary Fund).

Martijn, J.K., and C. Tsangarides, 2006, "Trade Reform in the CEMAC: Developments and Opportunities. Selected Issues,” IMF Country Report No.06/309, August 2006, (Washington: International Monetary Fund).

Masson, P., and C. Pattillo, 2005, “The Monetary Geography of Africa," (Washington: Brookings Institution Press).

Oliva, M., 2006, “Trade Policies in Congo,” mimeo, (Washington: International Monetary Fund).

UNECA, 2006, "The Case for Rationalization: The Inefficiency and Ineffectiveness of the Regional Economic Communities, in ARIA II: Rationalizing Regional Economic Communities," (Addis Ababa, Ethiopia: UNECA).

USAID, 2004, "National AGOA Strategy Report for Congo Brazzaville, in The East and Central Africa Global Competitiveness Trade Hub," (Washington: USAID).

World Bank, 2006, “Doing Business 2007,’(Washington: World Bank).

World Trade Organization, 2006, “Trade Policy Review," (Geneva: World Trade Organization).

Zafar, Ali, and Keiko Kubota, 2003, "Regional Integration in Central Africa: Key Issues," mimeo, (Washington D.C.: World Bank). 